UNIVERSIDADE DE SÃO PAULO

FACULDADE DE MEDICINA

RAFAEL MARTINS DE OLIVEIRA

\title{
Análise do perfil transcricional de células dendríticas derivadas de monócitos utilizadas na vacina terapêutica anti-HIV-1
}

São Paulo

2010 


\section{Análise do perfil transcricional de células dendríticas derivadas de monócitos utilizadas na vacina terapêutica anti-HIV-1}

Tese apresentada à Faculdade de Medicina da Universidade de São Paulo para obtenção do título de Doutor em Ciências

Área de concentração: Pato logia Orientador: Prof. Dr. Alberto José da Silva Duarte

São Paulo 
Autorizo a reprodução e divulgação parcial deste trabalho, por qualquer meio convencional ou eletrônico, para fins de estudo e pesquisa, desde que citada a fonte.

Dados Internacionais de Catalogação na Publicação (CIP)

Preparada pela Biblioteca da

Faculdade de Medicina da Universidade de São Paulo

Creprodução autorizada pelo autor

Oliveira, Rafael Martins de

Análise do perfil transcricional de células dendríticas derivadas de monócitos utilizadas na vacina terapêutica anti-HIV-1 / Rafael Martins de Oliveira. -- São Paulo, 2010 .

Tese(doutorado)--Faculdade de Medicina da Universidade de São Paulo.

Departamento de Patologia.

Área de concentração: Patologia.

Orientador: Alberto José da Silva Duarte.

Descritores: 1.Células dendríticas 2.Análise de sequência com séries oligonucleotídeos 3.Vacinas contra AIDS 4.Perfilação da expressão gênica 


\section{Dedicatória}

minha família, aos pacientes e todos aqueles que participaram desse estudo. 


\section{Agradecimentos}

Ao final desta jornada, gostaria de agradecer:

Ao Prof. Dr. Alberto J. S. Duarte pela oportunidade, liberdade e confiança para realização deste trabalho e pelos valorosos ensinamentos que carregarei pelo resto de minha vida.

Aos professores Dra. Anete Grumach, Dra. Maria Sato, Dr. Gil Benard, Dr, Jorge Casseb e Dr. Dewton Vasconcelos pela convivência enriquecedora no laboratório e por toda troca de conhecimentos e experiências.

À Dra. Telma Oshiro pela generosidade e paciência ao longo do desenvolvimento deste trabalho.

Ao Dr. Alexandre Almeida pelo bom humor e pelo recrutamento dos pacientes. 
A Dra Claudia Finazzo e Dr. Guilherme Silveira pelo companheirismo e auxílio com a citometria de fluxo.

Ao Wilton e Laís pelo cuidado e dedicação as culturas virais.

À Renata Pelegrino, responsável pelo centro facilitador em microarray da AFIP, pelas trocas de informações e realizações dos arrays,

Aos mais de 20 funcionários do LIM56 pelo suporte e amparo fundamentais para a realização das pesquisas. Em especial Edna, Adriana Costa, Luiz Carlos, Lucio, Ângelo, Juliana, Demétrius, é com grande satisfação que deixo esta homenagem a vocês, pois trabalharam com responsabilidade e dedicação.

À Adriana e Silvia devo a vocês os mais sinceros agradecimentos. Muito obrigado pelo trabalho que realizaram durantes estes anos, por serem responsáveis pela manutenção e tornarem o laboratório um ambiente mais agradável. 
À Fundação de Amparo a Pesquisa do Estado de São Paulo (FAPESP) pelo apoio no desenvolvimento deste trabalho.

Aos quase 8 anos de convivência no LIM-56 que me fizeram adquirir grandes amizades, as quais considero verdadeiras e sinceras. Agradeço a vocês: Anna, Léia, Mayce, Daniela Cardeal, Lisméia, Luciano, Camila, Soraya, Guilherme, Paula, Ciro, Jeff, Telma, Claudinha, Vivi, Fabio, Rosana, Noêmia, Rosangela, Karen, Liã, Andréia, Erica, Luciana, Fernando. Obrigado pelo companheirismo.

Agradeço especialmente aos meus pais, por sempre me auxiliarem quando precisei. Pelo carinho, amor e educação que me foram dados; por todos os incentivos, pelas oportunidades, pela formação do meu caráter e por todo meu sustento. Sem a ajuda de vocês não chegaria até onde cheguei.

Às minhas irmãs Juliana e Mariana, eternas amigas e companheiras de todos os momentos. Cada uma de vocês tem um lugar especial no meu coração. 
Ao meu sogro Luiz e Sra. Marisa (ou Meire para os íntimos) por fazerem parte da minha vida e por todo carinho e incentivo dado, e por compreenderem as razões das minhas ausências.

À minha sogra Eliane e ao Sr. Evaldo pelo carinho e afeto que tenho recebido durantes esses anos. Sou grato por serem e fazerem parte da minha vida.

Agradeço especialmente àquela que é a minha inspiração, minha fortaleza, minha alegria, uma pessoa que permanece em minha vida pela vontade e graça de Deus, minha querida e amada esposa Adriana. Tua bondade me ensina a cada dia, sobre o companheirismo, simplicidade, paciência, amizade, carinho e amor. Obrigado pela paciência em todos os momentos de alegria, satisfação, desentendimentos, nervosismo, desespero, tristezas, felicidade e conquistas.

Agradeço a Deus, que por sua graça e compaixão tem me sustentado e permitido enfrentar os obstáculos deste mundo com segurança e paz. Por tuas promessas e tudo o que és, eu quero agradecer te com todo o meu ser. 


\section{RESUMO}

Oliveira, RM. Análise do perfil transcricional de células dendríticas derivadas de monócitos utilizadas na vacina terapêutica anti-HIV-1 [tese]. São Paulo: Universidade de São Paulo, Faculdade de Medicina, 2010. 141f.

Aplicando tecnologia de microarray, objetivamos traçar o perfil do programa de maturação das Mo-DC pulsadas com HIV autólogo inativado por AT-2, a fim de identificar marcadores específicos de ativação funcional e sugerir um perfil de expressão de genes úteis na identificação de respostas ao modelo in vitro das Movacina DC. Essas informações podem ajudar a estabelecer assinaturas moleculares das funções celulares mais relevante para a melhoria das vacinas terapêuticas. $\mathrm{O}$ perfil transcricional foi analisado com base das vias celulares moduladas das MoDCs no estado imaturo, transitório e maduro. O HIV-1 inativado por AT-2 induz ativação de genes associados à apresentação de antígenos. Os conjuntos de genes do citoesqueleto podem influenciar a mudança de comportamento migratório das MoDCs ativadas. O aumento na expressão dos receptores celulares contribuem para o recrutamento de monócitos, DCs e macrófagos para o local da infecção. Além disso, modulam a resposta imune inata e adaptativa, incluindo a polarização das células Th e sub-regulação da resposta inflamatória, que pode interferir significativamente com a resposta imune. Coletivamente, o perfil transcricional das Mo-DCs induzido pelo HIV-1 inativado com AT-2 reflete uma significativa reprogramação imunológica e celular das células envolvidas na resposta imune do hospedeiro. Os resultados deste estudo focaram na interpretação de genes específicos dos perfis de transcrição das Mo-DCs como modelo terapêutico utilizado na vacina anti-HIV. As análises de assinaturas gene associado e sua correlação as respostas funcionais simplificam a identificação de indivíd uos susceptíveis a vacina e a compreensão de eventuais falhas em ensaios clínicos. Microarray permitiu a análise quantitativa e simultânea da expressão de um elevado número de genes. Os estudos do perfil de expressão foram extremamente úteis para identificar os eventos moleculares e vias envolvidas nas funções de celular induzida por estímulos específicos. Em particular, os resultados sobre o padrão global da expressão dos genes subjacentes as modificações induzidas pelo HIV-1 inativado por AT-2, na fase inicial da administração do antígeno, pôde ser extremamente útil para a identificarmos marcadores de ativação e avaliar os efeitos biológicos que poderiam estar envolvidos para modificação e otimização de estratégias vacinação com Mo-DC.

Descritores: 1.Células dendríticas; 2.Análise de sequência com séries oligonucleotídeos; 3.Vacinas contra AIDS; 4.Perfilação da expressão gênica. 


\begin{abstract}
Oliveira, RM. Transcription profile of monocyte derived dendritic cells used in therapeutic HIV-1 vaccine model [thesis]. São Paulo: Faculdade de Medicina, Universidade de São Paulo, 2010. $141 \mathrm{f}$.

Applying microarray technology, we intend to profile the program to mature Mo-DC pulsed with autologous inactivated HIV by AT-2, in order to identify specific markers of functional activation and suggest a profile of expression of specific genes, useful identification of responders to in vitro model of Mo-DC vaccine. Such information may help to establish detailed molecular signatures of cellular functions most relevant to improving the therapeutic vaccines. The transcriptional profile was analyzed on the basis of the cellular pathways modulated in immature MoDC, transitional MoDC and mature MoDC. The AT-2-inactivated HIV-1 induction of MoDC results in the activation of genes associated with antigen presentation functions. A set of cytoskeletal genes that may potentially mediate shape change and migratory behavior of activated MoDC is also observed. The increase in the expression of immune receptors contribute to the recruitment of monocytes, DCs, and macrophages to the site of infection. Moreover, they modulate both innate and adaptive immune response, including the polarization of Th cells, and the down-regulation of the inflammatory response, which may significantly interfere with the immune response. Collectively, the transcriptional profile ind uced by AT-2-inactivated HIV-1 in MoDc reflects a significant cellular and immunological reprogramming of cells directly involved in the host immune response. The results of this study focused on the interpretation of specific genes of transcription profile of MoDC used in therapeutic HIV vaccine model. Supplementing the analyses with examination of associated gene signatures and their correlation to functional responses will simplify the identification of "responsive" vaccine individuals and the understanding of eventual failures in individuals enrolled in clinical trials. Microarray approach allows quantitative and simultaneous analysis of gene expression of a large amount of genes and the systematic studies of expression patterns are extremely useful for identify molecular events and key pathways involved in cellular functions induced by specific stimuli. In particular, data on the global pattern of gene expression underlying the modifications induced by AT-2inactivated HIV-1 in MoDC, at early stages of antigen administration, may be extremely helpful for the identification of exclusive activation markers to trace the biological effects of modifications/optimizations of the MoDc vaccination strategy.
\end{abstract}

Descriptores: 1. Oligonucleotide Array Sequence Analysis; 2. Dendritic Cells; 3. AIDS Vaccines; 4. Gene Expression Profiling 


\section{LISTA DE FIGURAS}

Figura 1. Mapa da distribuição de casos no mundo

Figura 2. Diversidade genética do HIV

Figura 3. Distribuição global das CRF

Figura 4. Unidades e frações antigênicas do HIV exploradas na confecção de vacinas.

Figura 5: Foto da agulha robótica utilizada nas técnicas de deposição mecânica para fabricação de microarray.

Figura 6: Diagrama da técnica de fotolitografia para fabricação de microarray.

Figura 7: Diagrama ilustrativo spotted arrays.

Figura 8: Diagrama ilustrativo GeneChip ® HGU133 plus 2

Figura 9: Diagrama ilustrativo do GeneChip ${ }^{\circledR}$ HGU133 plus 2.

Figura 10: Desenho da construção de sequências nucleotídeas perfect match (PM) e mismatch (MM).

Figura 11. Esquema de extração de RNA nos três momentos da cultura celular.

Figura 12. Esquema de extração de RNA da cultura celular.

Figura 13. Esquema do protocolo de amplificação em dois ciclos.

Figura 14. Microscopia óptica de células dendríticas derivadas de monócitos

Figura 15. Perfil fenotípico de Mo-DC de indivíduos sadios - controle 1

Figura 16. Perfil fenotípico de Mo-DC de indivíduos sadios - controle 2

Figura 17. Perfil fenotípico Mo-DC do paciente n. 8

Figura 18. Perfil fenotípico Mo-DC do paciente n.11

Figura 19. Perfil fenotípico Mo-DC do paciente n.12

Figura 20. Perfil fenotípico Mo-DC do paciente n.14 
Figura 22. Perfil de avaliação do RNA das amostras dos pacientes.

Figura 23. Composição do perfil de avaliação do RNA das amostras dos pacientes.

Figura 24. Amplificação da imagem do array 86

Figura 25. O gráfico de controle de marcação 88

Figura 26. O gráfico de controle de hibridização. 88

Figura 27. O gráfico de controle de controle interno. 88

Figura 28. Histograma de distribuição de sinal. 90

Figura 29. Gráfico de intensidade de sinais. 90

Figura 30. Gráfico de Sinal de Expressão. 90

Figura 31. Gráfico de razão de mudança expressão (FC) em T0. 93

Figura 32. Gráfico de razão de mudança expressão (FC) em T1.

Figura 33. Gráfico de razão de mudança expressão (FC) em T1 95

Figura 34. Gráfico de razão de mudança expressão (FC) em T2. 96

Figura 35. Histograma de funções biológicas de T0. 104

Figura 36. Histograma de funções biológicas de T1. 105

Figura 37. Histograma de funções biológicas de T2. 106

Figura 38. Mapa da via de Sinalização GM-CSF, Macropinocitoses e 108 Signalização TGF- $\beta$ em T0.

Figura 39. Mapa de via de movimento celular e tráfego de células imunes em 109 T1

Figura 40. Mapa de via para receptores de célula T e reposta imune em T1

Figura 41 Mapa da via do Interferon em T2. 


\section{LISTA DE TABELAS}

Tabela 1. Resumo dos principais ensaios de vacina terapêutica anti-HIV/MoDC.

Tabela 2. Resumo dos dados dos pacientes selecionados para o estudos

Tabela 3. Genes diferencialmente expressos (DEG).

Tabela 4. Os 10 genes mais superregulados e rerimidos em T0.

Tabela 5. Os 10 genes mais superregulados e reprimidos em T1.

Tabela 6. Os 10 genes mais superregulados e reprimidos em $\mathrm{T} 2$.

Tabela 7. Funções celulares e moleculares dos genes diferencialmente expressos em T0, T1 e T2.

Tabela 8. Funções e desenvolvimento fisiológico relacionados ao genes 102 diferencialmente expressos em T0, T1 e T2.

Tabela 9 Doenças e desordens relacionados ao genes diferencialmente 103 expressos em T0, T1 e T2.

Tabela 10. Vias canônicas de T0, T1 e T2. 


\section{LISTA DE ABREVEATURAS E SIGLAS}

ACTG

ADCC

ADEE-3002

AFIP

Aids

APC

ARC

ARV

ART

AT-2

Bonzo/STRL33

$\mathrm{CC}$

CCR2

CCR3

CCR5

CCR7

CCR8

CCR9

$\mathrm{CRF}$

CXCR4

CD1a

CD3

CD4

CD8

CD14

CD40

CD40L
Laboratory Technologist Committe

Citotoxicidade celular dependente de anticorpo

Ambulatório de Imunodeficiências Secundárias do Serviço de Dermatologia do HC/FMUSP

Associação Fundo de Incentivo à Psicofarmacologia

Síndrome da Imunodeficiência Adquirida

Células apresentadoras de antígenos

Association pour la Recherche sur lê Câncer

Antiretroviral

Terapia antiretroviral

Aldrithriol-2

Receptor para quimiocina

Família de quimiocinas - CC (baseado na posição de cisteína)

Receptor de quimiocina 2

Receptor de quimiocina 3

Receptor de quimiocina 5

Receptor de quimiocina 7

Receptor de quimiocina 8

Receptor de quimiocina 9

Formas Recombinantes Circulantes

Receptor de quimiocina 4

Classe de diferenciação 1a

Classe de diferenciação 3

Classe de diferenciação 4

Classe de diferenciação 8

Classe de diferenciação 14

Classe de diferenciação 40

Glicoproteína de membrana ou antígeno diferenciação expressa na superfície das células $\mathrm{T}$ 
Proteína integral da membrana da superfamília de

CD54 imunoglobulinas também conhecida como molécula de adesão intercelular-1 (ICAM-1)

CD58

Classe de diferenciação 58

CD80

Classe de diferenciação 80

CD83

Classe de diferenciação 83

CD86

Classe de diferenciação 86

CDC

Centro de Controle e Prevenção de Doenças

CFA

Correspondente fator de análise

CPDA-1

Citrato, fosfato, dextrose, adenina

COLSAN

Associação Beneficente de Coleta de Sangue

$\mathrm{CpG}$

Motivos desmetilados de DNA

CTL

Linfócitos T citolíticos

CV

Carga viral

Cy3

Fluorocromo Cyanine-3 e Cyanine-5

Cy5

Fluorocromo Cyanine-5

DC

Célula dendrítica

DCs

Plural de células dendríticas

DC-LAMP

Glicoproteína de membrana associado a lisos somo

DC-SIGN

Molécula de adesão célula específica

DD

Display Diferencial

DMSO

Dimetilsulfóxido

DNA

Ácido desoxirribonucléico

cDNA

Ácido desoxirribonucléico complementar

DEG

Detecção de genes diferencialmente expressos

DST

Doença sexualmente transmissível

dNTP

Desoxinucleosídeo trifosfato

EBI

European Bioinformatics Institute

Env

Gene do envelope viral

EUA

Estados Unidos da Ámérica

FC

Razão de mudança expressão

FDR

Determinação da taxa de descobertas falsas 
FITC

gag

GAPDH

GEO

GM-CSF

gp41

gp120

HAART

HC/FMUSP

$\mathrm{HCV}$

HIV-1

HIV-VLPs

HLA

HLA-DR

HSP

HSV

ICAM-1

IL-1 $\beta$

IL-2

IL- 4

IL-6

IL-10

IL12

IL-12p70

IL-15

IMT

INF- $\gamma$

IV

IVT

LB
Isotiocianato de Fluoresceína

Gene do core viral do HIV

Gliceraldeido-3-fosfato dehidrogenase

Gene Expression Omnibus

Fator de estimulação de colônia de macrófagos

Glicoproteína 41

Glicoproteína 120

Terapia Anti-retroviral Altamente Ativa

Hospital das Clínicas da Faculdade de Medicina da Universidade de São Paulo

Vírus da hepatite $\mathrm{C}$

Vírus da Imunodeficiência Humana Tipo 1

Modelo vacinal baseado no uso da partícula vírus símile do HIV1

Antígeno leucocitário humano

Antígeno leucocitário humano-DR

Proteínas de choque térmico

Vírus herpes simplex genital

A molécula de adesão intercelular-1

Interleucina $1 \beta$

Interleucina 2

Interleucina 4

Interleucina 6

Interleucina 10

Interleucina 12

Molécula recombinante da interleucina 12

Interleucina 15

Instituto de Medicina Tropical

Interferon-gama

Intravenoso

Reação de transcrição in vitro

Linfócito B 


\begin{tabular}{|c|c|}
\hline LCMV & Vírus da coriomeningite linfocítica \\
\hline LFA-3 & Linfócito função-associado antígeno 3 \\
\hline LIMMA & Linear Models for Microarray Analysis \\
\hline LIM56 & Laboratório de Investigação Médica 56 \\
\hline LPS & Lipopolissacarideos bacterianos \\
\hline MALT & Tecido linfóide associado à mucosa \\
\hline MAS & Algoritmo 5.0 \\
\hline MBEI & Multiplicative Model-Based Expression Index \\
\hline MIAME & Minimum Information About a Microarray Experiment \\
\hline MHC I e II & Complexo principal de histocompatibilidade classe I e classe II. \\
\hline MGED & Microarray Gene Expression Data Society \\
\hline MM & Mismatch \\
\hline Mo-DCs & células dendríticas derivadas de monócitos \\
\hline MVA - & vírus da varíola bovina \\
\hline NCBI & National Center for Biotechnology Information \\
\hline PAMPs & $\begin{array}{l}\text { Receptores de reconhecimento de padrões moleculares de } \\
\text { microrganismos }\end{array}$ \\
\hline PBMCs & Células mononucleares do sangue periférico \\
\hline PCA & Principal componente de análise \\
\hline $\mathrm{PE}$ & Ficoeritrina \\
\hline PECy5 & Ficoeritrina Cianina 5 \\
\hline $\mathrm{PGE}_{2}$ & Alfa-galctosilceramida \\
\hline PHA & Fitohemaglutinina \\
\hline PM & Perfect match \\
\hline nef & Gene fator negativo \\
\hline NIAD & Instituto Nacional de Doenças infecciosas \\
\hline $\mathrm{NIH}$ & Instituto Nacional de Saúde \\
\hline NK & Linfócito Natural Killer também conhecido como NKT \\
\hline PAM & Análise de predição para microarrays \\
\hline PBMC & Células mononucleares de sangue periférico \\
\hline PBS & Tampão fosfato salino \\
\hline PCR & Reação em cadeia de polimerase \\
\hline
\end{tabular}




\begin{tabular}{|c|c|}
\hline PLIER & Probe Logarithmic Intensity Error \\
\hline pol & Gene da polimerase \\
\hline RankProd & Rank Product Non-Parametric Method \\
\hline RMA & Algoritmo Robust Multi-array Average \\
\hline GC-RMA & Algoritmo Robust Multi-array Average \\
\hline RNA & Ácido ribonucléico \\
\hline RNAm & Ácido ribonucléico mensageiro \\
\hline cRNA & Ácido ribonucléico complementar \\
\hline RNAse & Tipo de enzima que cataliza e degrada o ácido ribonucléico \\
\hline RPMI & Roswell Park Memorial Institute \\
\hline TBE & Tampão Tris-Borato \\
\hline Treg & Linfócito regulador \\
\hline TR & Transcriptase reversa \\
\hline T0 & Células no estado imaturo sem estímulo viral ou pré-pulso \\
\hline $\mathrm{T} 1$ & Células no estado transitório com estímulo viral ou pós-pulso \\
\hline $\mathrm{T} 2$ & Células no estado maduro ativadas \\
\hline SAGE & Serial Analys is of Gene Expression \\
\hline SFB & Soro Fetal Bovino \\
\hline $\mathrm{SC}$ & Subcutâneo \\
\hline SIVcpz & Vírus da Imunodeficiência Símia de chimpanzés \\
\hline SIVsmm & Vírus da Imunodeficiência Símia de sooty mangabeys \\
\hline SPM & Mapa espectral \\
\hline SVM & Máquinas de Vetores Suporte \\
\hline TCLE & Termo de Consentimento Livre e Esclarecido \\
\hline T-Trópico & Linfócito T trópico \\
\hline TNF- $\alpha$ & Fator de necrose tumoral alfa \\
\hline Th1 & Linfócito T auxiliar 1 \\
\hline Th2 & Linfócito T auxiliar 2 \\
\hline UNAIDS & Nações Unidas para AIDS \\
\hline UNIFESP & Universidade Federal de São de Paulo \\
\hline USP & Universidade de São Paulo \\
\hline
\end{tabular}




\section{SUMÁRIO}

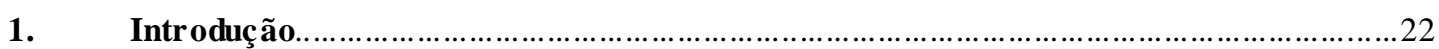



3. Revisão da liter atura

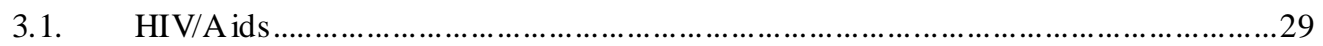

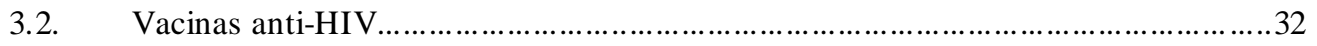

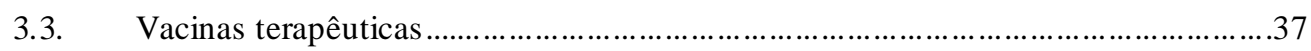



3.5. Genômica funcional / Transcripô mica........................................................... 46





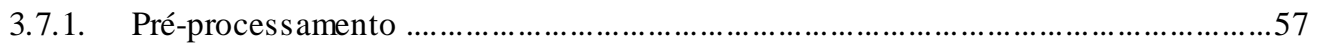

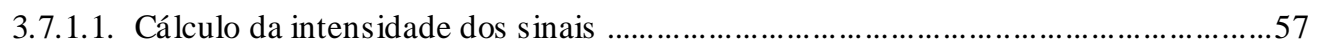

3.7.1.2. Correção do sinal de fundo (Background) ….................................................60

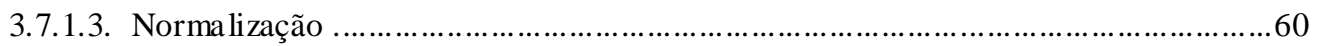

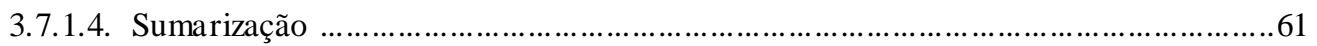



3.7.2.1. Detecção de genes diferencialmente expressos (DEG) .........................................63

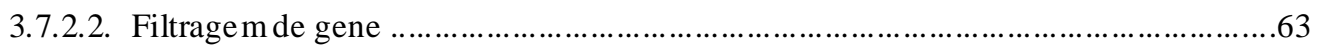





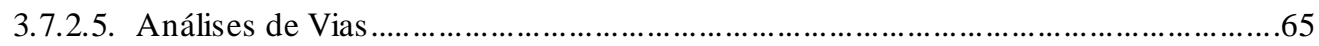



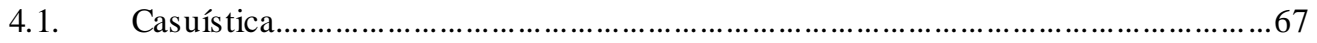

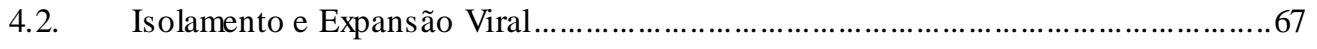

4.2.1. Separação de células mononucleares infectadas para isolamento viral...................68



4.2.3. Separação e ativação de células mononucleares sadias para expans ão viral...........69

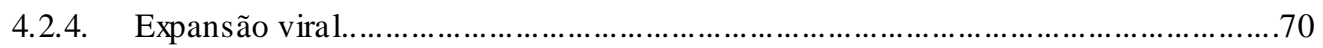

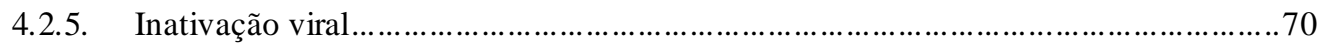

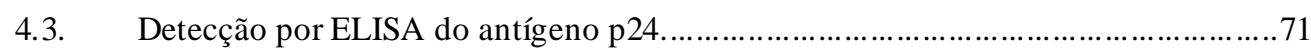

4.4. Geração de célu las dendríticas derivadas de monócitos (Mo-DCs) ........................72

4.5. Pulso e Ativação das Mo-DCs ................................................................... 73

4.6. Caracterização fenotípica das células dendríticas...............................................73

4.7. Avaliação quali-quantitativa do RNA extraído 4.8. Ensaio de Microarranjo

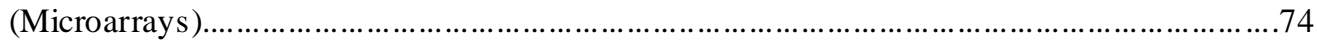

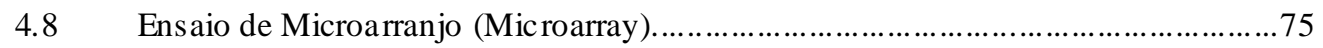




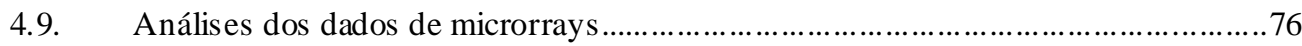

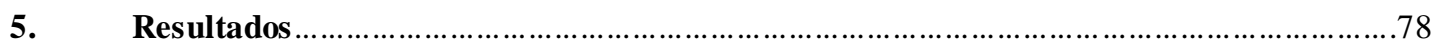

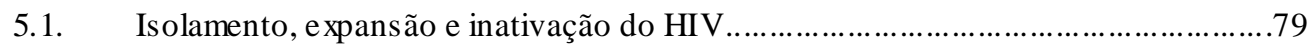

5.2. Diferenciação de Monócitos em Células Dendríticas ...........................................80

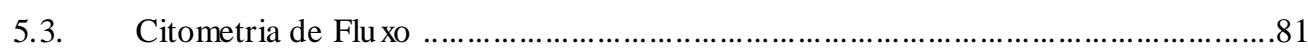

5.4. Avaliação quali-quantitativa do RNA e xtraído...................................................84



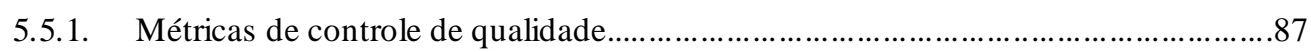



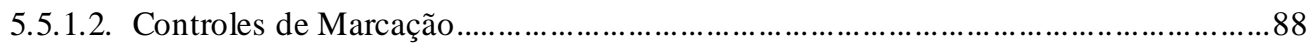

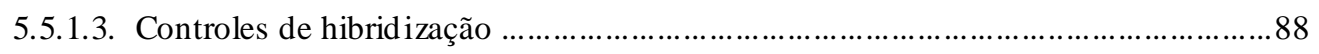

5.5.1.4. Controles Internos (Housekeeping Genes) …................................................ 88

5.5.2. Métricas de Análise de Expressão ......................................................................90

5.5.2.1. Histograma da intensidade de sinais das sondas ................................................. 90



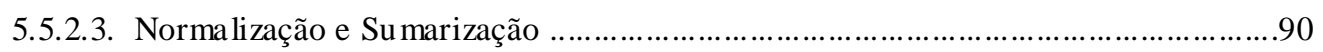

5.5.3. Genes diferencialmente expressos - DEGs ................................................92

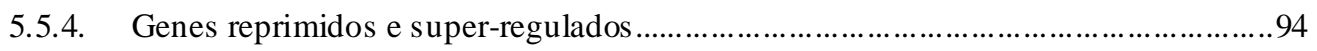

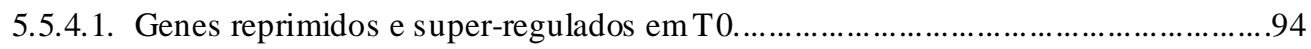

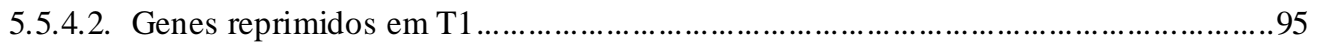

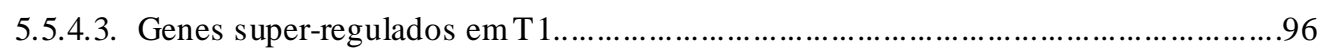

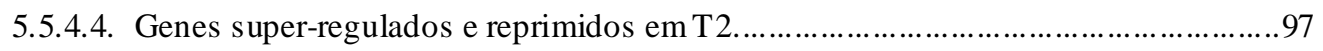

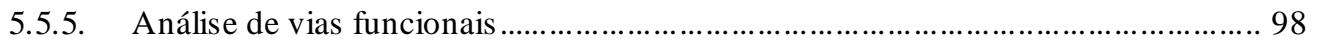

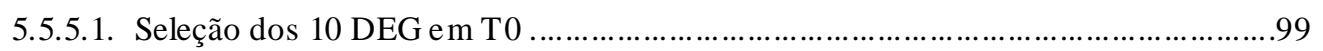

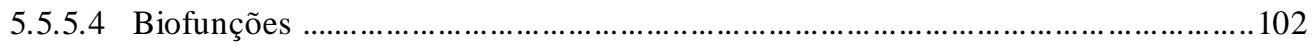

5.5.5.5. Representação gráfica das funções biológicas ................................................ 103

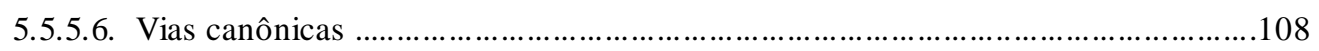

5.5.5.7. Grupo de mapas das redes funcionais ...................................................... 109

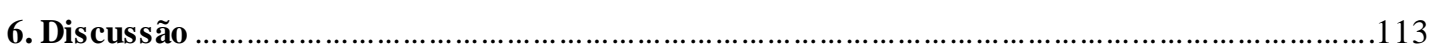

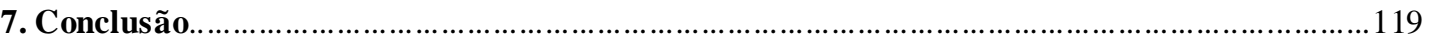





9.1 Ane

9.2 Ane






\section{Introdução}

A pandemia da Aids avança em média com três milhões de novas infecções a cada ano e atualmente ultrapassa a marca de 34 milhões de indivíduos infectados (UNAIDS, 2009). O desenvolvimento de estratégias eficazes no combate ao HIV constitui um dos principais objetivos, não só dos orgãos de saúde pública, mas também da comunidade científica (IAVI, 2008).

Neste sentido, estabeleceu-se no Brasil a primeira fase do estudo de uma vacina terapêutica baseada em células dendríticas derivadas de monócitos (Mo-DCs) pulsadas com HIV-1 autólogo inativado por Aldrithriol-2 (AT-2). Este modelo vacinal foi aplicado em pacientes cronicamente infectados pelo HIV-1 sem uso de antiretrovirais, o qual induziu supressão da carga viral a níveis inferiores a $10^{6}$ cópias/ml, por pelo menos um ano após a última dose da vacina em cinco dos dezoito participantes (Lu et al., 2004).

O êxito das vacinas baseadas em células dendríticas (DCs) é atribuído à sua potente função apresentadora de antígenos (APC), capaz de responder prontamente à presença de antígenos não-próprios e modular a resposta imune mediada por células T (Steinman e Cohn, 1973; Banchereau e Steinman, 1998; Usharauli, 2005). A magnitude e a natureza da resposta imune mediada por células $\mathrm{T}$ auxiliadoras ( $\mathrm{T}$ helper) Th1/Th2 e/ou células T citotóxicas (CTL) modulada pela vacina terapêutica anti-HIV1 dependerá, entre outros fatores, das alterações ocorridas nas Mo-DCs durante o processo de maturação induzido pelo vírus autólogo inativado utilizado no modelo vacinal de Lu et al., 2004. 
O processo de maturação das DCs envolve a regulação coordenada de centenas de genes. No entanto a maturação celular é rotineiramente mensurada considerando somente 5 a 10 marcadores presentes na superfície das DCs como o CD80, CD86, CD83, DC-LAMP, CD40, CCR7, e pela secreção de determinadas citocinas como IL-12 p70 e IL-10. Do programa de maturação das DCs mais de 95\% é efetivamente ignorado (McIlroy et al., 2005).

Para compreender a regulação genética das DCs, atualmente a tecnologia de microarranjos de DNA (microarray) possibilita analisar a expressão de milhares de genes em paralelo, úteis na identificação de eventos moleculares envolvidos nas mudanças morfológicas, fenotípicas e funcionais de determinada população celular induzidas por estímulos específicos in vitro e/ou in vivo (Schena et al., 1998; Brown e Botstein, 1999; Granucci et al., 2001; Messmer et al., 2003). Tal análise é conhecida como genômica funcional ou transcriptômica, e particularmente, poderá auxiliar no avanço do conhecimento molecular sobre a complexidade funcional da maturação das DCs (Castagnoli e Granucci, 2002; Ahn et al., 2002; Ju et al., 2003; Ju e Zenke, 2004)

A análise do perfil transcricional das Mo-DCs pela técnica de microarray tornou-se uma poderosa ferramenta no desenvolvimento de vacinas. Atualmente, sua maior aplicação é no monitoramento do status de maturação ou imunofenotipagem das DCs utilizadas na confecção de vacinas anti-tumor em ensaios clínicos (McIlroy et al., 2005).

Desta maneira, o presente estudo baseou-se no protocolo de vacina terapêutica anti-HIV proposto por Lu e colaboradores (2004), e propôs avaliar o transcriptoma de Mo-DC de indivíduos cronicamente infectados pelo HIV-1, 
aplicando a tecnologia de microarray, que permite detalhar as funções celulares mais relevantes ao aperfeiçoamento da vacina terapêutica, e sugerir um perfil de expressão gênica característico dos indivíduos responsivos ao modelo vacinal in vitro. 
OBJETIVOS 


\section{Objetivos}

Com o objetivo de contribuir para o entendimento do transcriptoma das células dendríticas derivadas de monócitos (Mo-DC) utilizadas no processo de confecção da vacina terapêutica anti-HIV bem como sugerir um perfil de expressão característica dos indivíduos responsivos in vitro ao modelo vacinal, pretendemos:

- Traçar o perfil de transcrição genética das Mo-DC em três momentos distintos da cultura: no estado imaturo ou basal, no estado transitório ou póspulso com HIV-1 inativado quimicamente e no estado maduro ou maturado com citocinas pró-inflamatórias.

- Analisar o perfil de transcrição obtido nos três momentos da cultura dividindo-o em principais categorias funcionais, baseado nas anotações gênicas encontradas em programas especializados em análise de vias funcionais.

- Baseado nas anotações funcionais determinar outros temas biológicos predominantes nas listas de genes que possam relacionar-se com a identificação de respondedores ao modelo vacinal. 
REVISÃO BIBLIOGRÁFICA 


\section{Revisão da lite ratura}

\subsection{HIV/Aids}

Estudos indicam que a síndrome da imunodeficiência adquirida (Aids) é uma zoonose cujo agente etiológico é o vírus da imunodeficiência humana (HIV), que atravessou a barreira entre os símios e humanos antes da metade do século XIX e, progressivamente, adaptando-se aos humanos através das práticas irregulares de injeções e transfusões de sangue na África pós-colonial (Gao et al., 1999; Korber et al., 2000).

Os primeiros relatos de Aids foram descritos em 1981 como um surto de pneumonia por Pneumocystis carinii, acompanhado por casos de sarcoma de Kaposi entre os homossexuais masculinos nos Estados Unidos da America (EUA) (Gottlieb et al., 1981; Masur et al., 1981). Inquéritos sorológicos e epidemiológicos posteriores mostraram que a doença se disseminou rapidamente para quase todos os países no mundo (Piot, 1998; Mastro et al., 1998).

A rápida disseminação do HIV resulta, entre outros fatores, dos seus modos de transmissão dentre os quais $90 \%$ ocorrem por intercurso sexual (vaginal, anal ou oral) nos adultos e adolescentes (transmissão horizontal), enquanto o restante é ocasionado pela troca de sangue e derivados, incluindo transfusões sanguíneas, reutilização de agulhas e seringas por usuários de drogas injetáveis (UID) e pela transmissão materno-infantil (transmissão vertical) durante pré-parto, parto ou pós- 
parto (Buve et al., 2001; Shattock e Moore, 2003; Strathdee et al., 1998; Des et al., 2001; Van de Perre et al., 1993; Pitt et al., 1997; Shaffer et al., 1999).

No início da década de 1990, a compreensão dos modos de transmissão forneceu as bases para os programas de controle e prevenção do HIV. Esforços globais focavam-se principalmente na mudança de comportamento encorajando a monogamia, o retardo da atividade sexual dos adolescentes, incentivo ao uso do preservativo, campanhas de sensibilização de outras doenças sexualmente transmissíveis (DST), bem como, o controle de doações de sangue e seus derivados. Apesar dos esforços para implementação dessas medidas, no mundo ainda ocorrem diariamente 7,4 mil novas infecções pelo HIV-1 e, no Brasil aproximadamente 15 mil óbitos já foram registrados (UNAIDS, 2009).

Atualmente, HIV/AIDS é a principal causa de morte na África subsaariana e quarta maior do mundo, atingindo entre 2.9 a 3.5 milhões de mortes/ano. Segundo o relatório epidemiológico global em AIDS da Organização Mundial da Saúde, em 2009 o número estimado de pessoas infectadas em todo mundo ultrapassava a marca dos 33 milhões (Figura 1) (UNAIDS, 2009).

Nos países industrializados a incidência de novas infecções pelo HIV e o número de mortes por AIDS, de um modo geral, estabilizou-se e caiu durante a década de 1990. O advento de novas drogas e a introdução em 1996 do esquema de terapia antiretroviral altamente potente ou HAART (Highly Active Antiretroviral Therapy) foram responsáveis pela queda na mortalidade e morbidade (Rosenberg et al., 1997; Richman, 2001).

O HAART consiste no uso combinado de três ou mais tipos de antiretrovirais, que apesar de provocar a supressão da replicação viral por tempo prolongado e 
permitir a restauração parcial da resposta imune, não é capaz de eliminar os reservatórios virais e garantir a reconstituição da resposta HIV específica perdendo sua eficácia (Kaufmann et al., 1998; Ledergerber et al., 1999; Flexner, 2007).

Dentre os aspectos associados à perda da eficácia do HAART estão os inúmeros efeitos adversos associados à exposição prolongada aos antiretrovirais (hepatotoxicidade, pancreatite, lipodistrofia, diabetes, dislipidemia e osteoporose), a emergência de mutações que conferem resistência às drogas e a dificuldade de aderência por parte dos pacientes aos regimes de longo prazo e de alto custo do tratamento (Shafer, 2002; Simon e Ho, 2003). Diante desses fatos, o desenvolvimento de uma vacina terapêutica e/ou profilática permitirá melhor controle da pandemia e da ameaça que representa ao desenvolvimento global (UNAIDS, 2009).

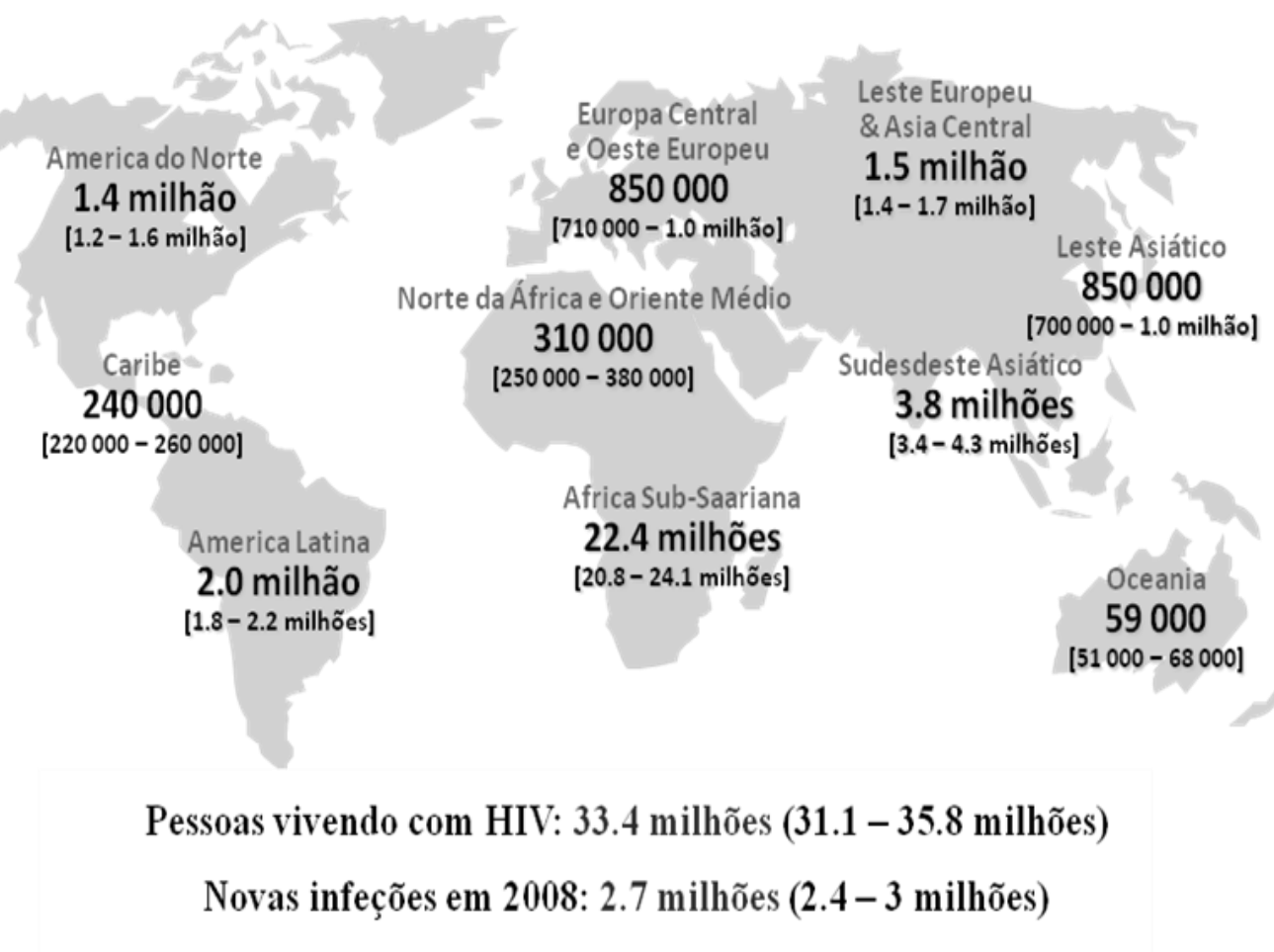

Figura 1. Mapa da distribuição de casos no mundo. Fonte: Modificado do relatório epidemiológico da UNAIDS 2009. 


\subsection{Vacinas anti-HIV}

Historicamente a vacinação ainda continua a ser uma das formas de medicina mais segura e de melhor relação custo-efetividade na saúde pública. Em conjunto com o conhecimento da teoria dos germes e do saneamento básico, a vacinação tem transformado vidas e economias nos últimos 50 anos por seu impacto direto na saúde (Nara et al., 2008).

Programas de vacinação bem sucedidos resultaram na erradicação da varíola e na expressiva redução de doenças como a poliomielite, febre tifóide, sarampo, entre outras (Nara et al., 2008). Naturalmente, a exemplo do sucesso da vacinação contra determinadas infecções contagiosas, almejam-se uma vacina contra o HIV-1 desde sua descoberta em 1983 (Barré-Sinoussi et al., 1983; Gallo et al., 1983).

O primeiro estudo clínico de fase 1 foi conduzido em 1987 nos EUA e, desde então, mais de 40 vacinas candidatas foram testadas em 65 estudos de fase 1 e 2 , envolvendo mais de 25.000 voluntários saudáveis distribuídos em cerca de 10 países, no entanto, somente três destas vacinas progrediram para estudos de fase 3 (Girard et al. 2006). Apesar dos esforços das agências de pesquisa, governos, universidades, empresas farmacêuticas e organizações internacionais, ainda não se encontram disponíveis vacinas seguras, efetivas, acessíveis e de fácil administração (IAVI 2008).

A experiência e o conhecimento acumulado com os estudos clínicos demonstraram que o HIV possui características particulares, que dificulta o desenvolvimento de uma vacina que tenha a mesma eficácia alcançada pelas vacinas dirigidas aos vírus, como exemplo, da varíola. Dentre essas características do HIV, podemos destacá-las seguir: (a) ser retrovírus; (b) apresentar hipervariabilidade 
filogenética; (c) alta diversidade antigênica, (d) escape dos anticorpos neutralizantes; (e) não possuir correlato de imunidade protetora e (f) ser incapaz de infectar modelos animais (IAVI, 2006; Letvin, 2006; Robinson, 2007; IAVI, 2008).

a. Retrovírus: o HIV apresenta tropismo por células que expressam maior número de receptores de superfície celular CD4 e, para a entrada na célula hospedeira, usa os co-receptores CCR5 e/ou CXCR4 que são receptores naturais de quimiocinas. Após infectar a célula, o HIV é capaz de retrotranscrever seu RNA em DNA proviral HIV e integrá-lo ao genoma das células hospedeiras, passando explorar o "maquinário" celular para criação de novas partículas virais. Em resposta a infecção, o sistema imune ativa vigorosa imunidade celular mediada por células assassinas naturais (NK) e linfócitos T citotóxicos (CTL) contra as células que apresentam os antígenos do HIV em sua superfície, provocando uma rápida e maciça depleção das células $\mathrm{TCD}^{+}$de memória, principalmente, no tecido linfóide associado à mucosa (MALT). Entretanto, determinadas células infectadas, como os linfócitos $\mathrm{T} \mathrm{CD}^{+}$de memória em repouso, não apresentam diferenças entre as células não-infectadas e passam desapercebidas pela resposta imune. Isto ocorre devido à capacidade do HIV manterse em estado latente após integrar seu genoma na célula hospedeira, as quais se tornam reservatórios ou "santuários" para o vírus, estabelecendo uma persistente e duradoura infecção. Esta integração ocorre nos primeiros 10 dias após a exposição criando uma pequena "janela" de oportunidade para ação de uma vacina de caráter profilático (IAVI, 2006; Letvin, 2006; Robinson, 2007; IAVI, 2008). 
b. Hipervariabilidade: Quando ativo, o HIV possui uma rápida replicação (10,3 x $10^{9}$ virions por dia) com uma elevada taxa de erros, gerando mutantes capazes de recombinar-se e formar cepas variantes. Por essa razão, o HIV-1 é dividido em três grupos: $\mathrm{M}$ (maior), $\mathrm{O}$ (outlier ou isolado) e $\mathrm{N}$ (não-M/não-O). $\mathrm{O}$ grupo $\mathrm{M}$, responsável pela pandemia global de Aids, é subdividido 9 em classes ou subtipos identificados pelas letras A, B, C, D, F, G, H, J, K (Figura 2). Ao longo do curso da epidemia, como resultado da superinfecção, isto é, quando o indivíduo se infecta novamente por uma variante do vírus diferente a da primeira infecção, as cepas de HIV podem recombinar-se formando um mosaico viral conhecido como Formas Recombinantes Circulantes (CRF), e ganhar uma posição epidemiológica dominante (Figura 3). Neste sentido, uma vacina anti-HIV deve levar em consideração a forma particular do HIV circulante em cada região do mundo, para que a mesma possa agir especificamente contra o vírus (IAVI, 2006; Letvin, 2006; Robinson, 2007; IAVI, 2008).

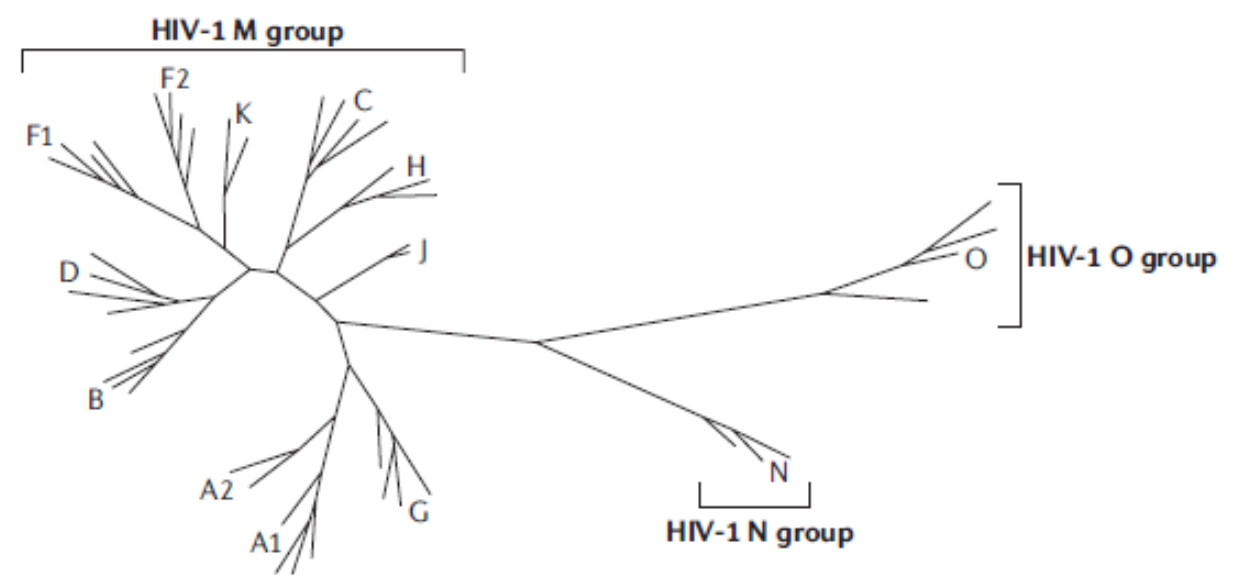

Figura 2. Diversidade genética do HIV: relação filogenética dos principais grupos e classes. Fontes: Letvin, 2006; 
c. Diversidade antigênica: As alterações genéticas resultantes da hipervariabilidade transformam o HIV em um alvo móvel para o sistema imune, dificultando a seleção de antígenos que induzem uma proteção eficaz. Similarmente, o desenvolvimento de vacinas depende da seleção de antígenos que apresentem maior imunogenicidade (IAVI, 2006; Letvin, 2006; Robinson, 2007; IAVI, 2008).

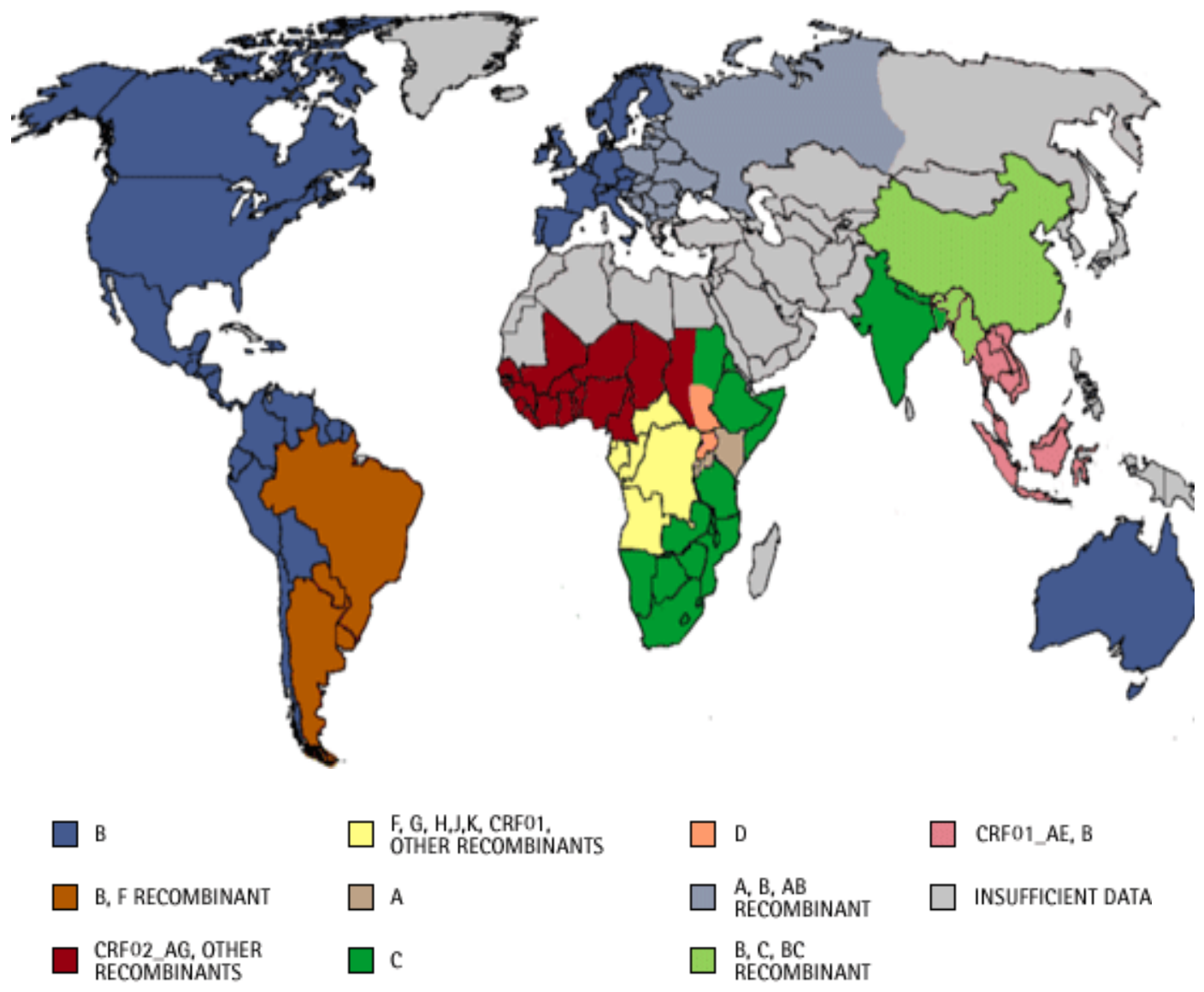

Figura 3. Distribuição global das CRF. Fontes: IAVI 2006.

d. Escape dos Anticorpos neutralizantes: Além da resposta celular, o sistema imune monta no primeiro momento uma resposta humoral capaz de neutralizar o vírus infectante, bem como despertar a citotoxicidade celular dependente de anticorpo (ADCC) e provocar lise de células infectadas pela ação da via anticorpo- 
dependente do sistema complemento (via clássica). No entanto, em razão da variabilidade dos antígenos, os anticorpos neutralizantes produzidos não são eficazes em alcançar os sítios de ligação do HIV nas células hospedeiras (receptor CD4) e/ou superar a densa matriz de carboidratos que recobre as proteínas de superfície do vírus (Env ou gp120), tornando sua ação praticamente nula (IAVI, 2006; Letvin, 2006; Robinson, 2007; IAVI, 2008).

e. Correlato de imunidade protetora: Em outras infecções virais, os indivíduos podem espontaneamente gerar uma resposta imune contra o patógeno e depurar a infecção. A análise destes indivíduos pode levar a identificação de marcadores de clareamento da infecção conhecido como correlato de imunidade protetora. $\mathrm{Na}$ infecção pelo HIV os mecanismos imunes antivirais falham, levando à diminuição progressiva dos clones de células $\mathrm{T}$ virgens e de memória, depleção sistêmica das células $\mathrm{TCD}^{+}$e $\mathrm{TCD}^{+}$e aumento da carga viral. Este profundo e irreparável dano ao sistema imunológico abre caminho para as infecções oportunistas e resulta na progressão clínica para AIDS. Portanto não há, até o momento, relatos de depuração viral e desenvolvimento de imunidade natural anti-HIV, dificultando o estabelecimento de um marcador válido para determinar quando uma vacina candidata tem maior efeito em relação à outra (IAVI, 2006; Letvin, 2006; Robinson, 2007; IA VI, 2008).

f. Modelo animal: Apesar do HIV-1 apresentar grande similaridade com o Vírus da Imunodeficiência Símia (SIVcpz) de chimpanzés (Pan t. troglodytes) e o HIV-2 com o Vírus da Imunodeficiência Símia (SIVsmm) de sooty mangabeys (Cercocebus atys), esses não são capazes desenvolver Aids nos primatas utilizados como modelo 
experimental. Desta maneira não há um modelo animal ideal para a Aids, limitando os pesquisadores a confiar em modelos animais substitutos com valor preditivo incerto (IAVI, 2006; Letvin, 2006; Robinson, 2007; IAVI, 2008).

\subsection{Vacinas terapêuticas}

O conhecimento das características do HIV permite à elaboração de desenhos de vacinas destinadas a prevenção (vacinas profiláticas) ou ao tratamento (vacinas terapêuticas) (Lemckert et al., 2004; Brander et al., 2006; Egan, 2007). O interesse particular pelas vacinas terapêuticas tem aumentado nos últimos anos devido às baixas perspectivas em relação às vacinas profiláticas e, principalmente pela possibilidade de diminuir ou até mesmo substituir o uso dos antiretrovirais, motivado pelo número de efeitos colaterais e pela perda de eficácia após longos períodos de tratamento (Dorrell, 2006).

Basicamente, as vacinas são compostas pela combinação dos diferentes tipos de antígenos do HIV (vírus inteiro inativo, proteínas, peptídeos, plasmídeos etc.) somados aos variados tipos de adjuvantes (Figura 4). Os adjuvantes possuem três funções principais: estabilizar o antígeno (incluindo o efeito de agregação e de depósito), entregar o antígeno e ativar a imunidade inata (Graham, 2006; Jones, 2008).

As vacinas terapêuticas têm apresentado diferentes resultados nas diversas composições antígeno-adjuvante (McMichael e Hanke, 2003). Em um levantamento de estudos clínicos com vacinas terapêuticas até 2006 (McMichael, 2006), verifificou-se que as estratégias que se concentraram na inoculação do HIV inteiro 
inativado e proteínas do envelope viral, como Remune, não apresentaram resultados satisfatórios (Kahn et al., 2000).



Figura 4. Unidades e frações antigênicas do HIV exploradas na confecção de vacinas. Fonte: Letvin, 2006.

Similarmente, vacinas de vetores virais recombinantes contendo genes do HIV como vírus da varíola aviária (canarypox e fowlpox) ou vírus da varíola bovina (MVA - Modified Vaccinia Ankara) falharam em manter uma resposta imune específica, apesar de apresentarem aumento da resposta de células $\mathrm{T}$ e pequena redução da carga viral (Markowitz et al., 2002; Lévy et al., 2005; Kilby et al., 2005).

Vacinas de DNA plasmidial codificante para o gene do HIV testadas em pacientes não tratados ou tratados com HAART, estimularam uma fraca resposta de células T (MacGregor et al., 1998; Dorrell et al., 2005). Por outro lado, imunização com células dendríticas (DCs) HLA compatíveis pulsadas com peptídeos (Kundu et 
al., 1998) e a imunização com DCs autólogas pulsadas com vírus inteiro inativado (Lu W et al., 2004) mostraram resultados contraditórios.

No primeiro estudo, Kundu (1998) e Shapero (2001), demonstraram que a utilização de DCs geradas in vitro a partir de monócitos (Mo-DC) de doadores HLA compatível ao paciente e pulsadas com antígenos recombinantes HIV-1 MN gp160 e peptídeos sintéticos (gag, env e pol), não apresentou reações adversas, porém não resultou em nenhuma melhoria significativa na resposta imune específica ao HIV ou na diminu ição da carga viral nos pacientes (Kundu et al., 1998; Shapero et al., 2000).

Em contrapartida, Lu e colaboradores (2003) ao realizarem estudos com primatas não-humanos, inocularam Mo-DC pulsada com vírus da imunodeficiência símia (SIV) inativado por Aldrithiol-2 (AT-2) em macacos previamente infectados pelo SIV e notaram que os animais apresentaram um aumento significativo na resposta celular e humoral SIV-específica e, conseqüentemente, redução na carga viral (Lu W et al., 2003).

Diante dos resultados promissores, estabeleceu-se no Brasil o estudo de fase 1 do modelo vacinal semelhante utilizando Mo-DC pulsadas com HIV-1 autólogo inativado por AT-2 em pacientes cronicamente infectados pelo HIV na ausência de HAART. Este protocolo vacinal induziu uma supressão da carga viral abaixo de $10^{6}$ cópias/ml em cinco dos dezoito participantes, mantida por pelo menos um ano após a última dose da vacina. Em oito dos dezoito participantes, cuja carga de RNA viral plasmática tinha permanecido constante nos seis meses anteriores, observou-se uma diminuição superior a $90 \%$ da carga viral em um período de 112 dias após a primeira inoculação. Entretanto, a resposta dos demais participantes foi mais fraca e transitória (Lu et al., 2004). 
Ensaios clínicos posteriores foram realizados por diferentes grupos de pesquisas com variações no protocolo de obtenção de células dendríticas, no processo de maturação e tipos de antígenos do HIV utilizado (Garcia et al., 2005; Ide et al., 2006; Connolly et al., 2008).

Tabela 1. Resumo dos principais ensaios de vacina terapêutica anti-HIV/Mo-DC.

\begin{tabular}{|c|c|c|c|c|c|c|c|}
\hline $\begin{array}{c}\text { Diferencia } \\
\text { ção }\end{array}$ & $\begin{array}{c}\text { Maturação } \\
\text { DC }\end{array}$ & $\begin{array}{c}\text { Antígenos } \\
\text { HIV }\end{array}$ & $\operatorname{Rota}^{1}$ & $\begin{array}{c}\text { Total } \\
\text { pacientes }\end{array}$ & $\begin{array}{c}\text { Resposta } \\
\text { Imunológica }^{2}\end{array}$ & Resposta Virológica & Ref. \\
\hline $\begin{array}{c}\text { IL-4 e } \\
\text { GM-CSF }\end{array}$ & $\begin{array}{c}\text { IL-4 } \beta, \text { IL-6 } \\
\text { e TNF- } \alpha\end{array}$ & $\begin{array}{c}\text { HIV } \\
\text { autólogo } \\
\text { inativado } \\
\text { com AT-2 }\end{array}$ & $\mathrm{SC}$ & 18 & 18 & $\begin{array}{c}\text { Queda no RNA viral } \\
\text { plasmático durante } 112 \text { dias; } \\
\text { redução >90\% na CV em } 8 \\
\text { pacientes }\end{array}$ & Lu 2004 \\
\hline $\begin{array}{c}\text { IL-4 e } \\
\text { GM-CSF }\end{array}$ & $\begin{array}{l}\text { Meio de } \\
\text { cultura } \\
\text { específico }\end{array}$ & $\begin{array}{c}\text { HIV } \\
\text { autólogo } \\
\text { inativado } \\
\text { com calor }\end{array}$ & $\mathrm{SC}$ & 12 & 0 & $\begin{array}{c}\text { Após a interrupção do } \\
\text { tratamento, houve diminuição } \\
\text { da CV em } \ddagger 0.5 \log 10 \\
\text { copias/mL e aumento no } \\
\text { tempo de duplicação em } \\
\text { quatro pacientes }\end{array}$ & $\begin{array}{l}\text { Garcia } \\
2005\end{array}$ \\
\hline $\begin{array}{c}\text { IL-4 e } \\
\text { GM-CSF }\end{array}$ & TNF- $\alpha$ & $\begin{array}{l}\text { Peptídeos } \\
\text { Gag, Env e } \\
\text { Nef }\end{array}$ & $\mathrm{SC}$ & 7 & 2 & $\begin{array}{c}\text { Não houve mudanças } \\
\text { significantes na CV após a } \\
\text { interrupção do tratamento }\end{array}$ & Ide 2006 \\
\hline $\begin{array}{c}\text { IL-4 e } \\
\text { GM-CSF }\end{array}$ & $\begin{array}{c}\text { IL-1 } \beta, \text { IL-6 } \\
\text { e TNF- } \alpha\end{array}$ & $\begin{array}{l}\text { Peptídeos } \\
\text { Gag, Env e } \\
\text { Pol }\end{array}$ & $\begin{array}{l}\text { IV, } \\
\text { SC }\end{array}$ & 18 & 16 & $\begin{array}{l}\text { Não houve mudanças } \\
\text { significantes na CV após a } \\
\text { interrupção do tratamento }\end{array}$ & $\begin{array}{c}\text { Connolly } \\
2008\end{array}$ \\
\hline
\end{tabular}

1. Rotas: SC subcutânea; IV intravenosa. 2. Resposta Imunológica é definida como qualquer evidencia de resposta HIV especifica por parte das células T após a inoculação da vacina.

\subsection{Células dendríticas: adjuvantes naturais}

O sucesso obtido com protocolos de vacinação baseados em células dendríticas não é recente, muitos estudos já demonstraram sua eficácia no combate ao câncer (Schuler et al., 2003) e contra um amplo espectro de doenças infecciosas mediadas por bactérias, parasitas, fungos e vírus, por exemplo, contra infecções 
causadas pelas bactérias Borrelia burgdorferi (Mbow et al., 1997), Clamídia tracomatis (Su et al., 1998), Micobacterium tuberculosis (Demangel et al., 1999), Bordetella pertussis (George-Chandy et al., 2001); infecções fúngicas e parasitárias causadas pela Candida albicans (d'Ostiani et al., 2000), Toxoplasma gondii (Bourguin et al., 1998), Leishmania major (Flohé et al., 1998; Berberich et al., 2003), ou Leishmania donovani (Ahuja et al., 1999) e infecções virais causadas pelo vírus da coriomeningite linfocítica (LCMV) (Ludewig et al. 1998), Influenza (López et al., 2000), vírus herpes simplex genital (HSV) (Schön et al., 2001). Protocolos de vacinas com DCs têm sido aplicados com resultados variados.

O êxito das vacinas baseadas em DCs é atribuído à potente função apresentadora de antígenos (APC), que consiste na capacidade das DCs de responder prontamente à presença de antígenos próprios e não-próprios, iniciando e regulando a resposta mediada por células T (Steinman e Cohn, 1973; Banchereau e Steinman, 1998). As DCs constituem uma população heterogênea de células com potencial funcional e características fenotípicas distintas; identificadas de acordo com a expressão de marcadores de superfície e a distribuição no sangue, órgãos linfóides e tecidos de interface com o meio externo (mucosas e a epiderme) (Shortman e Liu, 2002; Usharauli, 2005).

Devido às similaridades com os monócitos e macrófagos em relação a sua distribuição, morfologia, fenótipo e funcionalidade (atividade enzimática e capacidade endocítica e/ou fagocítica), originalmente, as DCs foram consideradas ser derivadas de precursores mielóides (Steinman e Cohn, 1973). Evidências geradas por diferentes abordagens experimentais demonstram que as DCs de camundongos e 
humanos podem efetivamente ser geradas tanto de precursores mielóide quanto de precursores linfóides (Banchereau et al., 2000).

As informações atuais que tratam da ontogenia das DCs são controversas e não permitem uma conclusão definitiva quanto da diferenciação fisiológica das células dendríticas (Ardavin et al., 2001; Liu, 2001). Em poucos anos, um grande número de informações foi acumulado sobre as propriedades funcionais das células dendríticas, contudo, os determinantes genéticos e moleculares que regulam os diferentes aspectos de sua biologia, como o estado funcional de maturação e desenvolvimento dos subtipos, ainda são pouco compreendidos (Granucci et al., 2001; Huang et al., 2001; Adams et al., 2005; Reis e Sousa, 2006).

No estado funcional imaturo, as DCs comportam-se como sentinelas do sistema imune, residindo no sangue, pele e mucosas, expressam diversos receptores capazes de reconhecer citocinas pró-inflamatórias, proteínas de choque térmico (HSP), imuno-complexos, células apoptóticas e outros sinais. Também expressam receptores de reconhecimento de padrões moleculares de microrganismos (PAMPs) especializados em identificar carboidratos e lipossacarides bacterianos (LPS), motivos desmetilados de DNA (CpG) e RNA viral. Muitos deles possuem função adicional, como iniciadores da sinalização intracelular ou mediadores da interação célula-célula (Fanger et al., 1996; Albert et al., 1998; Adams et al., 2005).

A expressão dos diferentes tipos de receptores permite a discriminação e captura de antígenos que serão internalizados por fagocitose, endocitose ou macropinocitose em compartimentos lisossomais após o contato. Este contato provoca o acionamento do programa gênico de diferenciação, conhecido como maturação, que se caracteriza pela ativação de vias de sinalização intracelular e 
fatores de transcrição gênica, resultando na redução da captura de antígenos, aumento da expressão de moléculas do complexo de histocompatibilidade I e II (MHC I e II), moléculas co-estimulatórias (CD80, CD83, CD86, CD40) e pela secreção de múltiplas quimiocinas e citocinas (IL-12, IL-18 e IL-10) (Fanger et al, 1996; Albert et al., 1998; Banchereau et al., 2000; Liu, 2001; MacDonald et al., 2002).

Estas modificações permitem que as DCs interajam com moléculas de adesão (CD54/ICAM-1, CD58/LFA-3, ALCAM) e migrem via linfáticos aferentes até áreas ricas em células $\mathrm{T}$ nos linfonodos periféricos, onde irão apresentar os antígenos, via CD1a ou MHC I/II aos linfócitos TCD4 ${ }^{+}$(Th1 ou Th2) e TCD8 ${ }^{+}$específicos (CTL), além de estimular a expansão clonal dos linfócitos $\mathrm{T}$ virgens e influenciar diferentes classes de linfócitos (NKT, Treg, NK e B) (Liu et al., 2001; Steinman, 2001; Gluckman, et al., 2002 McKenna et al., 2005).

Alterações nas atividades funcionais das DCs estão fortemente associadas a diferentes aspectos da imunopatogênese do HIV/AIDS desempenhando um papel complexo e controverso durante a infecção (Weissman e Fauci, 1997; Knight, 2001; Lore e Larsson, 2003).

Neste contexto, as DCs no estado imaturo expressam um maior número de receptores CD4 e de co-receptores (CCR5, CXCR4, CCR2, CCR3, Bonzo/STRL33, CCR8 e CCR9) requeridos no processo de infecção do HIV-1 na célula alvo (Rubbert et al., 1998; Douek et al., 2002; Teleshova et al., 2003; Collman et al., 2003). Por outro lado, ainda no estado imaturo as DCs são ávidas em capturar o HIV1 via receptores de lectina tipo-C (DC-SIGN, DC-LAMP, Receptor de Manose, DEC-205) sofrem maturação e migram até os linfonodos, onde irão secretar 
múltiplas citocinas e apresentar epítopos do HIV às células $\mathrm{TCD}^{+}$e $\mathrm{TCD} 4^{+}$virgens, tornando-as células efetoras (Donaghy et al., 2004; Larsson, 2005).

O estabelecimento da resposta efetora $\mathrm{T} \mathrm{CD}^{+}(\mathrm{CTL})$ e da polarização de $\mathrm{T}$ $\mathrm{CD}^{+}$(Th1 ou Th2) dependerá primariamente do perfil de citocinas secretadas e do repertório de peptídeos processados e apresentados pelo MHC I ou II das DCs, ambas com produção e expressão aumentada durante o processo de maturação das DCs (Donaghy et al., 2004).

Classicamente, as células $\mathrm{TCD}^{+}$reconhecem peptídeos (8-11 aminoácidos) derivados de proteínas citosólicas endógenas apresentados pelo MHC classe I, presente na maioria das células do organismo. Especificamente, a resposta citotóxica $\mathrm{TCD}^{+}$(CTL) desencadeada pela DCs via MHC I provoca citólise direta de células infectadas e a secreção de fatores de supressão viral importantes no controle da infecção do HIV (Hogan e Hammer, 2001).

Esse papel foi recentemente demonstrado in vitro, utilizando Mo-DC imatura, proveniente de pacientes em uso de HAART, submetidas à exposição com HIV-1 inteiro inativado por AT-2 (pulso passivo). Ao sofrerem maturação, as DCs pulsadas foram capazes de induzir a expansão de células $\mathrm{TCD}^{+}$de memória que erradicaram células infectadas e o vírus da cultura celular, independente do estágio da doença e do status da resposta do paciente ao HAART (Lu e Andrieu, 2001a; Lu e Andrieu, 2001b).

Tipicamente, as células $\mathrm{T} \mathrm{CD}^{+}$reconhecem peptídeos (10-15 aminoácidos) provenientes de proteínas exógenas processadas pelo sistema endossomal/lisossomal apresentado via MHC classe II presente nas APCs. A resposta auxiliadora T CD4 ${ }^{+}$ tem se mostrado ser essencial na manutenção da resposta CTL e humoral anti-HIV, 
pois ao serem ativadas pela DCs, as células $\mathrm{T} \mathrm{CD}^{+}$passam a secretar IL-2, 12, 15, IFN-alfa e outras citocinas capazes de aumentar a diferenciação e a expansão clonal de linfócitos B e T CD8 ${ }^{+}$(Donaghy et al., 2004).

Dessa maneira, a magnitude e a natureza da resposta de células T (CTL ou Th1/Th2) que se deseja induzir com a vacina terapêutica Mo-DC dependerá, entre outros fatores, das alterações no processo de maturação das DCs exercidas pelos tipos de antígenos do HIV e métodos de manipulação das células empregados na confecção da vacina (Donaghy et al., 2004).

O processo de maturação das DCs constitui um extenso programa de diferenciação que envolve a regulação coordenada de centenas de genes. Idealmente, a avaliação da maturação das DCs deve levar em conta a expressão de todos esses genes. Entretanto, a maturação é rotineiramente mensurada utilizando de 5 a 10 marcadores de superfície como CD80, CD86, CD83, proteínas de membrana associada a lisossomo de DC (DC-LAMP), CD40, receptor de quimiocina 7 (CCR7), e duas ou três moléculas secretadas como IL-12 p70 e IL-10. Conseqüentemente, mais de $95 \%$ do programa de maturação das DCs é efetivamente ignorado (McIlroy et al., 2005).

Atualmente, a biologia molecular dispõe de tecnologia capaz de auxiliar na avaliação de extensos programas genéticos, possibilitando analisar a expressão de milhares de genes em paralelo e estudar sistematicamente os padrões de expressão úteis na identificação de eventos moleculares e vias que envolvem funções celulares induzidas por estímulo específico (Castagnoli e Granucci, 2002; Ahn et al., 2002; Ju et al., 2003; Ju e Zenke, 2004). 


\subsection{Genômica funcional / Transcripômica}

Alterações morfológicas, fenotípicas e funcionais de populações celulares num determinado estágio de desenvolvimento ou interagindo com o meio a qual se encontra, é resultado da ação integrada dos produtos gênicos expressos e transformados em proteínas. Diante deste fato, novos recursos tecnológicos foram desenvolvidos para correlacionar os genomas à suas funções biológicas através estudo das moléculas, transcritos ou proteínas que são expressos, resultando na criação da área da pós-genômica (Marques e Silva, 2004).

A área da pós-genômica apesar de dividirem-se em ramos específicos, muitos apresentam sobreposição de propósitos, entre os ramos temos: genômica funcional ou transcriptômica, proteômica, peptidômica, metabolômica, fisiômica, regulômica, epigenômica, farmacogenômica, toxicogenômica, imunômica, entre outras (Marques e Silva, 2004; Binneck, 2004).

A formulação da hipótese na pós-genômica envolve geralmente a seguinte pergunta: quais genes estão expressos em uma dada situação? A resposta é obtida através da avaliação da genômica funcional/transcriptoma e/ou proteoma do sistema biológico estudado. Sua interpretação consiste na tentativa da reconstituição do fenômeno biológico em si, o que pode ser um grande desafio. Investigar porque ou como um determinado gene está expresso, em uma determinada situação, requer conhecer não apenas a estrutura de seus produtos, transcritos e proteínas, como também a sua interação com os produtos de outros genes (Mir, 2000; Vidal, 2001).

O primeiro passo neste sentido é dado pela transcriptômica, que dispõe de tecnologias que permitem a análise em grande escala de transcritos como o Diferential display (DD), Serial Analysis of Gene Expression (SAGE) e 
microarranjos de DNA (microarrays). Dentre estas, a tecnologia microarray é atualmente a mais robusta e amplamente aplicada no estudo de expressão ou perfilação transcricional de genomas completos de diferentes populações de células, em especial do sistema imune (imunoma), submetidas a condições e estímulos variados (Granucci et al., 2001; Huang et al., 2001; Messmer et al., 2003).

Por exemplo, análises trascricionais de células alvos (TCD4, macrófagos) e não-alvos (NK, LB, DCs) pelo HIV-1 revelaram a intensa modulação de genes envolvidos na desregulação imune, susceptibilidade à apoptose, replicação viral e persistência viral quando submetidas in vitro ou in vivo à exposição pelo HIV-1 ou por suas proteínas acessórias, colaborando no entendimento da correlação funcional da modulação genética na patogênese do HIV-1 in vivo (Giri et al., 2006).

Diversos trabalhos de análise de perfil transcricional foram realizados, entre 1998 e 2004, para identificar genes envolvidos na maturação de células dendríticas derivadas de monócitos (Mo-DCs) submetidas a diferentes estímulos próinflamatórios (LPS, manana, alfa-galctosilceramida, $\left.\mathrm{PGE}_{2}, \mathrm{CD} 40 \mathrm{~L}\right)$; citocinas (IFNgama, TNF-alfa IL-6, IL-1), drogas (Captopril), hormônios (Angiotensina II) e a exposição à microrganismos como E. coli, Influenza, Toxoplasma gondii, Leishmania donovani e Cândida albicans (Tang e Saltzman, 2004).

Especificamente, Izmailova e colaboradores (2003) identificaram 33 genes que codificam fatores de transcrição, fatores relacionados à apoptose, proteínas induzidas por stress e proteínas antivirais durante a exposição à três subtipos do HIV1 (BAL, ADA e JR-FL) e pela transfecção do vetor adeno-Tat em Mo-DC imaturas de doadores saudáveis, revelando um novo papel da proteína Tat na reprogramação 
da expressão genética que favorece a expansão da infecção viral (Izmailova et al. 2003).

Harman e colaboradores (2006) demonstraram que genes codificantes do grupo de moléculas marcadoras de maturação de células dendríticas, como CD40, CD83, CD80 (moléculas co-estimulatórias) e CXCR4 (molécula de adesão), foram diferencialmente mais expressos em Mo-DC tratadas com altos títulos do HIV-1 $\mathbf{B a L}$

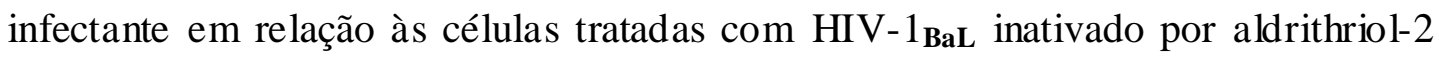

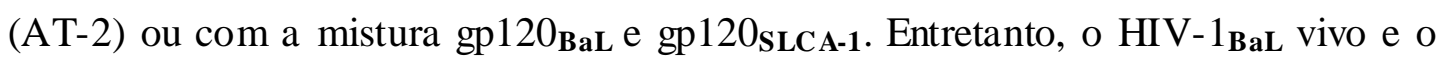

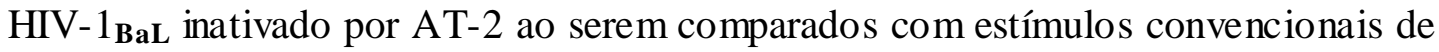
maturação de DCs ( $\mathrm{PGE}_{2}$, TNF-alfa, IL-beta, IL-6) foram igualmente capazes de provocar importantes mudanças na expressão dos marcadores de maturação das MoDC (Harman et al., 2006).

As mudanças provocadas pelo $\mathrm{HIV}-1_{\text {BaL }}$ inativado por AT-2 tais como a baixa-regulação dos receptores de lectina tipo-C (DC-SIGN e Receptor de Manose) e a alta-regulação de CCR7 e CD86, apesar menos extensas foram significantes após 24hs e acentuadas após $48 \mathrm{hs}$. Esses achados foram confirmados por citometria de fluxo demonstrando forte correlação entre as mudanças transcricionais e póstranscricionais (Harman et al., 2006).

A aplicação da tecnologia de microarray no desenvolvimento de vacinas foi discutida pela Dra. Karin J. Regnström no livro Pharmacogenomics in the Preclinical Development of Vaccines. Segundo a autora, ao introduzir a análise de expressão gênica e bioinformática no desenho de vacinas e seus sistemas de entrega, o desenvolvimento de uma vacina pode ser melhorado e acelerado consideravelmente. Cada combinação de antígenos vacinais e sistemas de entrega são 
caracterizados por um perfil genômico único, uma "impressão digital" que poderá fornecer informações não apenas das respostas imunológicas e toxicológicas, mas também outras respostas celulares relacionados ao ciclo celular, apoptose, efeitos cancerígenos, entre outros. Os resultados destas "impressões digitais" genômica únicas, facilitam o estabelecimento da relação entre as estruturas moleculares e a atividade farmacológica das vacinas, otimizando seu desenvolvimento (Regnström, 2008).

O exemplo prático desta afirmação foi à criação de um chip ou lâmina de DNA exclusivo para a análise de DCs (DC-chip), financiado pela associação francesa de pesquisa do câncer (Association pour la Recherche sur lê Câncer ARC), o qual contém uma seleção de pouco mais de 300 genes relevantes à imunobiologia das DCs e se destina ao monitoramento do status de maturação ou imunofenotipagem de DCs utilizadas na confecção de vacinas anti-tumores para ensaios clínicos (McIlroy et al., 2005).

No estudo de vacinas anti-HIV, Aricò e colaboradores (2005) associaram a metodologia de microarray e ensaios funcionais para determinar a resposta imune ao modelo vacinal baseado no uso da partícula vírus símile do HIV-1 Pr55gag (HIVVLPs), produzida pelo sistema de expressão de baculovirus. Do ponto de vista funcional, a transfecção desse vetor foi capaz de induzir a maturação das DCs resultando na expressão de marcadores de maturação na superfície celular e também foi capaz de aumentar a produção de citocinas polarizantes Th1 e estimular a resposta primária e secundária de células $\mathrm{T} \mathrm{CD}^{+}$autólogas no ensaio de imunização in vitro. Do ponto de vista genético, entre as vias e os genes especificamente ativados nas Mo-DCs, foram observados aqueles que estão envolvidos diretamente na 
maturação e na ativação funcional, em particular na ativação de genes relacionados ao controle celular (proliferação, diferenciação, migração e homeostase) e à atividade funcional de apresentação de antígenos (APC), ativação de células T e polarização da resposta Th (Aricò et al.,2005)

O perfil transcricional das Mo-DCs também revelou uma diferença na suscetibilidade ao tratamento com o Pr55gag entre os doadores, sugerindo a possibilidade de seleção de padrões de expressão de genes específicos úte is na identificação dos respondedores a este tratamento (Aricó et al., 2005).

\subsection{Microarrays}

A idéia de usar arranjos de ácidos nucléicos com o propósito de analisar simultaneamente o maior número possível de genes começou a ser aplicada no final da década de 70, com o advento da técnica conhecida como Dot-Blot (Kafatos et al., 1979). Contudo, foi somente na metade da década de 90 que esta tecnologia adquiriu as características atuais (Schena et al.,1995).

A tecnologia de microarray é o resultado da convergência de variadas técnicas e metodologias provenientes da biologia molecular, genética, química combinatória, robótica, bioinformática, etc. Sua construção e desenvolvimento exigem o trabalho conjunto de profissionais de diferentes áreas do conhecimento científico, o que limitava sua existência a poucos laboratórios de pesquisa altamente especializados (Schena et al.,1995).

Os arranjos de DNA, também conhecidos como chips de DNA em alusão ao componente eletrônico miniaturizado que carrega milhões de transistores, são coleções de segmentos de material genético (sondas) representativos dos genes de 
uma determinada espécie que se encontram depositados sobre um substrato sólido em um padrão o regular (Chaudhuri, 2005). Estas sondas tendem a ligar-se pelo processo de hibridização apenas a sua seqüência complementar de nucleotídeos (alvos) extraída de amostras biológicas previamente marcadas com substâncias fluorescentes (Jaluria et al., 2007).

Após o processo de hibridização, todos os chips de DNA são lavados para remoção dos "alvos" excedentes (que não se ligaram às sondas) e, em seguida, exposta à ação de raios laser que excitam os fluoróforos que foram incorporados aos "alvos", fazendo com estes emitam luz (fluorescência). Em princípio, quanto maior for a expressão de um determinado gene, maior será a quantidade de "alvos" marcados com o fluoróforo e, conseqüentemente, maior será a intensidade da fluorescência do complexo alvo sonda após a hibridização. Assim, a tecnologia de microarrays fornece uma medida indireta do nível de expressão gênica, mediante quantificação da abundância dos RNAs transcritos (Hiendleder et al., 2005).

Entretanto, a tecnologia básica de microarrays descrita acima apresenta diversas variações, dependendo do substrato, tipo de sonda, do método de deposição, além de uma variedade de técnicas de extração e marcação do RNA, bem como de protocolos de hibridização (Rogojina et al., 2003).

O substrato sólido utilizado pode ser de diferentes materiais (lâmina de vidro, sílica, plástico, membranas de nylon, nitrocelulose etc.). As sondas pode ser compostas de oligonucleotideos de cadeia longa (45 a 70 mer), cDNAs produzidos em projetos de seqüenciamento, produtos de amplificação por PCR (reação em cadeia da polimerase) ou oligonucleotideos de cadeia curta (25 mer) (Venkatasubbarao, 2004). 
Da mesma maneira, as forma de deposição das sondas também variam, mas duas são as mais comuns: deposição mecânica e síntese in situ. A primeira, mais simples, é feita por robôs de alta precisão que utilizam agulhas especiais para depositar as sondas na superfície a lâmina na forma de spots (elemento circular criado pela sonda) (Venkatasubbarao, 2004).

A segunda baseada na sintese in situ, mais complexa, utiliza processos especiais como a fotolitografia, impressão a jato ou sintese eletroquímica para realizar a síntese química de oligonucleotídeos sintéticos de cadeia curta (25 mer) diretamente sobre a superfície do substrato (Walsh e Henderson, 2004).

A distinção mais importante entre as diferentes tecnologias existentes referese ao número de amostras hibridizadas em cada lâmina. Neste sentido, os diversos tipos de tecnologias de microarrays podem ser divididos em dois grupos básicos: sistema de uma cor ou canal único (single-color ou single-channel microarray) e sistema de duas cores, dois canais (two-color ou two-channel microarray) ou sppoted array, também são referidas por lâminas de hibridizações independentes e lâminas de hibridizações competitivas, respectivamente (Venkatasubbarao, 2004). 


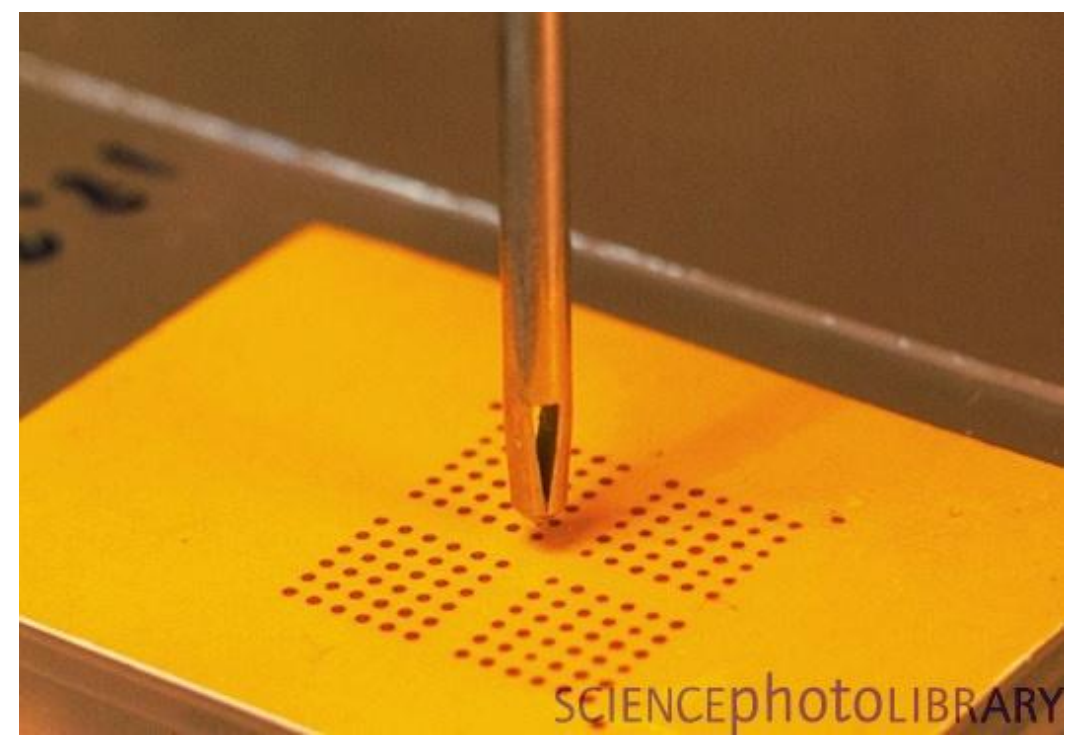

Figura 5: Foto da agulha robótica utilizada nas técnicas de deposição mecânica para fabricação de microarray. Fonte: Science Photo Library
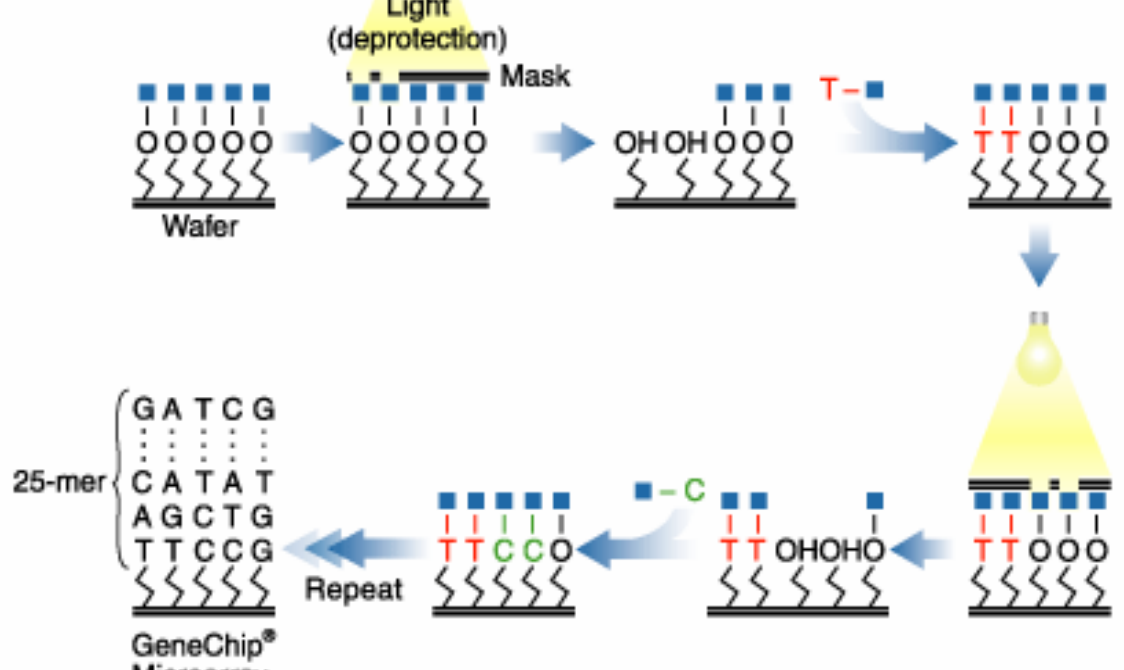

Microarray

Figura 6: Diagrama da técnica de fotolitografia para fabricação de microarray. Fonte: Affy metrix Inc.

No sistema de hibridizações competitivas (spotted arrays), as amostras de RNA são individualmente transcritas reversamente e marcadas com diferentes fluorocromos (geralmente Cyanine-3 e Cyanine-5, também referidos como Cy3 e 
Cy5), e então pares de amostras diferentemente marcadas são hibridizadas conjuntamente em uma lâmina, permitindo uma comparação direta entre amostras (por exemplo, controle versus tratamento). A comparação entre amostras numa mesma lâmina é dada pela razão entre as intensidades de fluorescência relativas ao Cy3 e Cy5 (relativas a diferentes comprimentos de ondas, representadas pelas cores verdes e vermelhas) em cada spot, a qual é uma medida da expressão relativa do gene correspondente nas duas amostras. Uma descrição mais detalhada deste processo pode ser encontrada, por exemplo, em Brown e Botstein (1999).

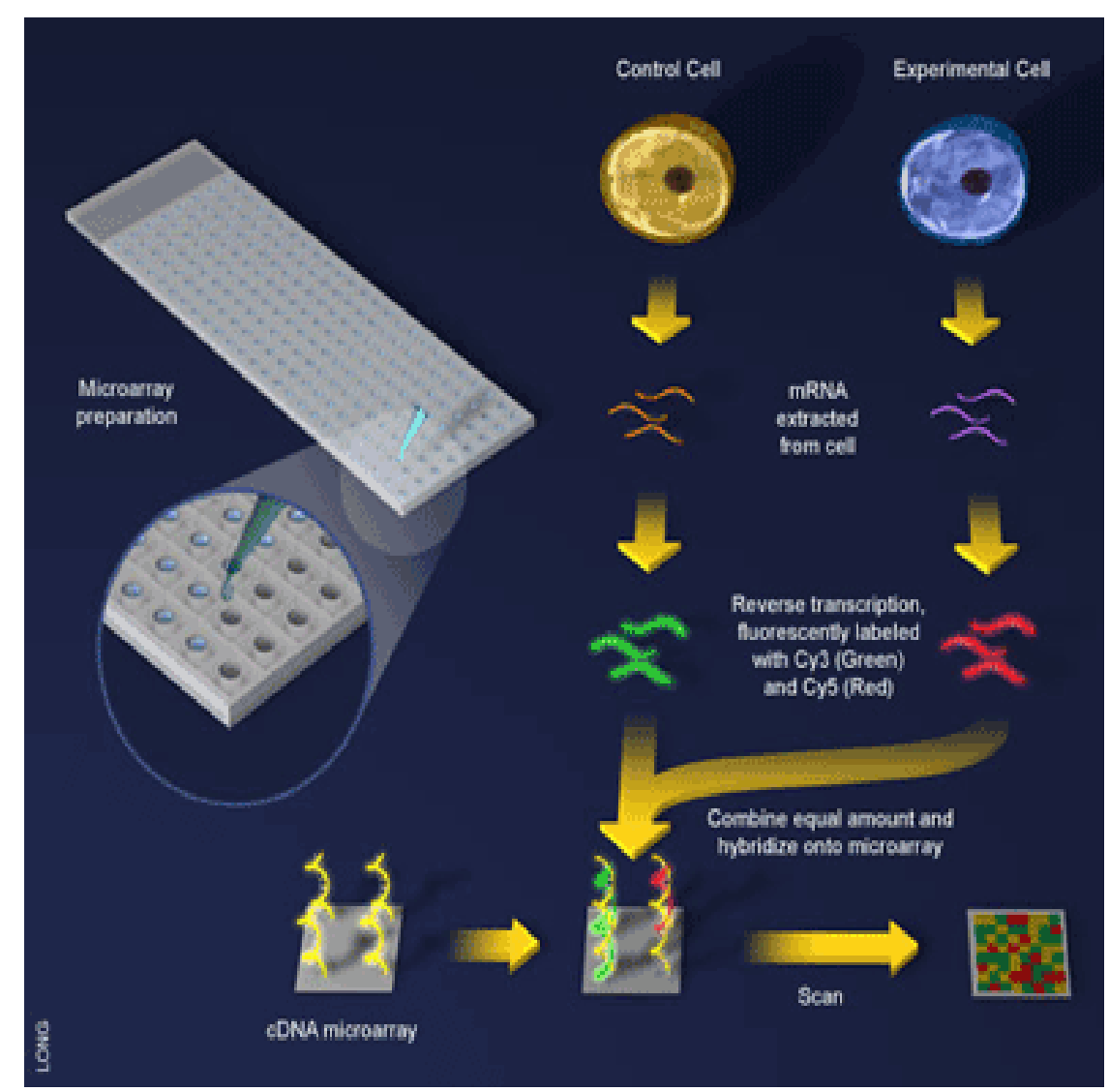

Figura 7: Diagrama ilustrativo spotted arrays. Fonte: Long

No sistema com hibridizações independentes (canal único), cada amostra de RNA é marcada e hibridizada individualmente numa lâmina. A vantagem deste tipo de tecnologia esta no fato dos estudos serem conduzidos de maneira mais 
simplificada e flexível, tanto de um ponto de vista experimental como estatístico. Outra vantagem, esta na superior qualidade dos chips de DNA comerciais em relação aos sistema de hibridizações competitivas produzidos in house, o que permite aos cientistas gastarem menos tempo na otimização de aspectos técnicos e dedicarem maior atenção no planejamento e aplicação da tecnologia de microarray para responder as questões biológicas (Venkatasubbarao, 2004).

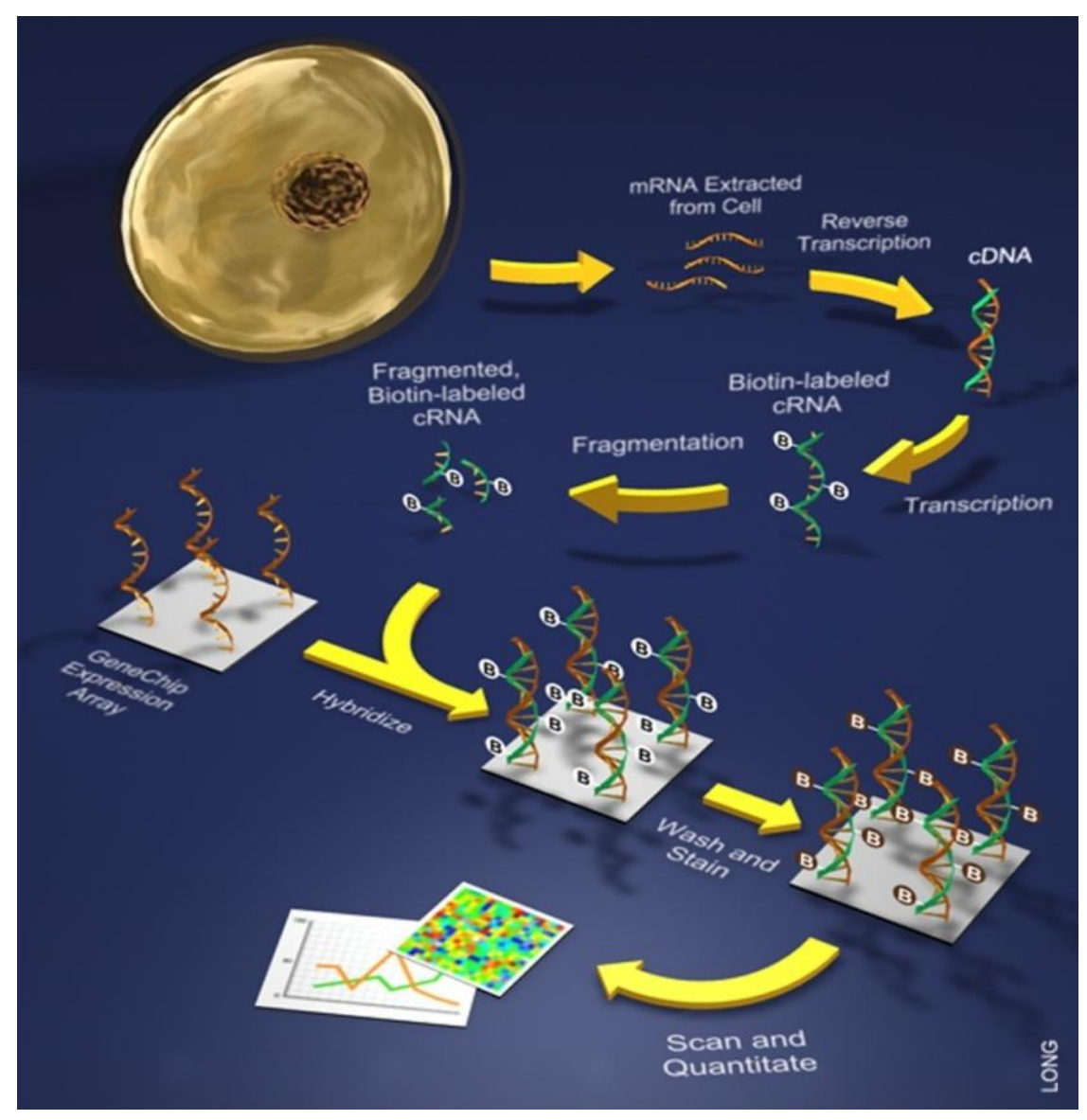

Figura 8: Diagrama ilustrativo GeneChip. Fonte: Long.

A plataforma Affymetrix é um exemplo da tecnologia de microarray com hibridizações independentes de canal único, mais amplamente adotado em laboratórios acadêmicos, bem como em clínicas e entidades comerciais. Diante das 
vantagens e seguindo o exemplo de outros laboratórios em nossa instituição adotamos tal plataforma para este estudo.

\subsection{Análise de dados de microarrays}

Organizações como a Microarray Gene Expression Data Society - MGED e o European Bioinformatics Institute - EBI, têm estabelecido guias de orientação que auxiliam os pesquisadores a planejar e programar seus experimentos com microarrays, cujo objetivo é padronizar as variantes dessa tecnologia, para que os resultados obtidos em experimentos diferentes possam ser comparados e utilizados como base para o planejamento de novas pesquisas sobre o mesmo tema. Um desse guias é o Minimum Information About a Microarray Experiment (MIAME), que contém diversas recomendações e padrões para coleta e análise de dados provenientes de experimentos com microarrays, para que estes possam ser corretamente interpretados e reproduzidos (Jaluria et al., 2007).

Outra tentativa interessante é o compartilhamento dos dados brutos obtidos em experimentos com microarrays, uma vez que não é possível incluir esse tipo de informação nas publicações. Dois bancos de dados criados com essa finalidade são o Gene Expression Omnibus (GEO), iniciativa do National Center for Biotechnology Information (NCBI) e o ArrayExpress, mantido pelo EBI.

Apesar destas iniciativas não há um padrão estabelecido para as análises, existindo vários métodos e programas a disposição. A escolha do método para análise é um processo que cabe ao pesquisador considerar o desenho experimental, tipo celular estudado, pergunta biológica e levantar as vantagens e devantagens dos 
métodos que podem garantir um melhor dessenpenho diante de sua aplicação. Para plataformas comerciais estabelecidas e bem difundidas como a plataforma Affymetrix, artigos e livros especializados mostram que as análises dos dados geralmente envolvem duas etapas: Pré-processamento e Análise de dados (Stekel, 2003; Korenberg, 2007; Göhlmann e Talloen, 2009).

\subsubsection{Pré-processamento}

O pré-processamento ou análise primária visa eliminar fontes indesejáveis de variação de modo que as estimativas de expressão obtida reflitam mudanças verdadeiras nos transcritos de forma tão precisa e acurada possível. As fontes de variação originam-se nas diferentes fases do processo de fabricação dos microarrays (variação entre lotes de GeneChips), do experimento biológico (isolamento do RNA, heterogeneidade de tecidos, variação inter-individual) e do ensaio de microarray (transcrição reversa do mRNA em cDNA, eficiência na marcação das sondas) ((Stekel, 2003; Korenberg, 2007; Göhlmann e Talloen, 2009).

Podemos considerar o pré-processamento como uma sequência de passos no cálculo da intensidade do sinal para cada sonda, transformação logarítmica dos valores de intensidade, correção do sinal de fundo (Background), normalização e sumarização dos valores encontrados (Stekel, 2003; Korenberg, 2007; Göhlmann e Talloen, 2009).

3.7.1.1 Cálculo da intensidade dos sinais: A imagem é capturada pelo sistema GeneChip® Scanner 3000 Affymetrix, que possui um laser sólido de diodo verde $(532 \mathrm{~nm})$ e um conjunto de lentes objetivas flutuantes (Flying 
Objective $^{\mathrm{TM}}$ Lens - FOL). O laser incide sobre sondas de oligonucleotídeos sintéticos de cadeias curtas (25 mer) contidas em seções de $11 \mu \mathrm{m}^{2}$ (probe cell) na superficie de silicio $\left(1,28 \mathrm{~cm}^{2}\right)$ dos GeneChips®. Cada gene é representado por um grupo de sondas (Probe set) compostas 11 a 20 pares de probe cell (Figura 9).

Cada par de probe cell é constituido de sondas complementares e nãocomplementares a porção do gene alvo, isto é, as sondas ditas perfect match (PM) possuem uma sequencia complementar baseada em uma parte da sequencia de referencia do gene alvo, enquanto seu par correspondente conhecido como mismatch (MM) possui uma sequencia idêntica exceto pela troca de um oligonucleotideo na $13^{\circ}$ posição (Figura10) (Lipshutz et al., 1999).

A Affymetrix adota esta metodologia na construção de seus GeneChips para minimizar os efeitos do fenômeno da hibridização cruzada que ocorre entre as sondas e trânscritos de diferentes genes que possuam sequencias parecidas. Esta estratégia fornece dados que podem ser utilizados para a determinação do nível de expressão dos genes representados nos grupos de sondas (Figura 10). 


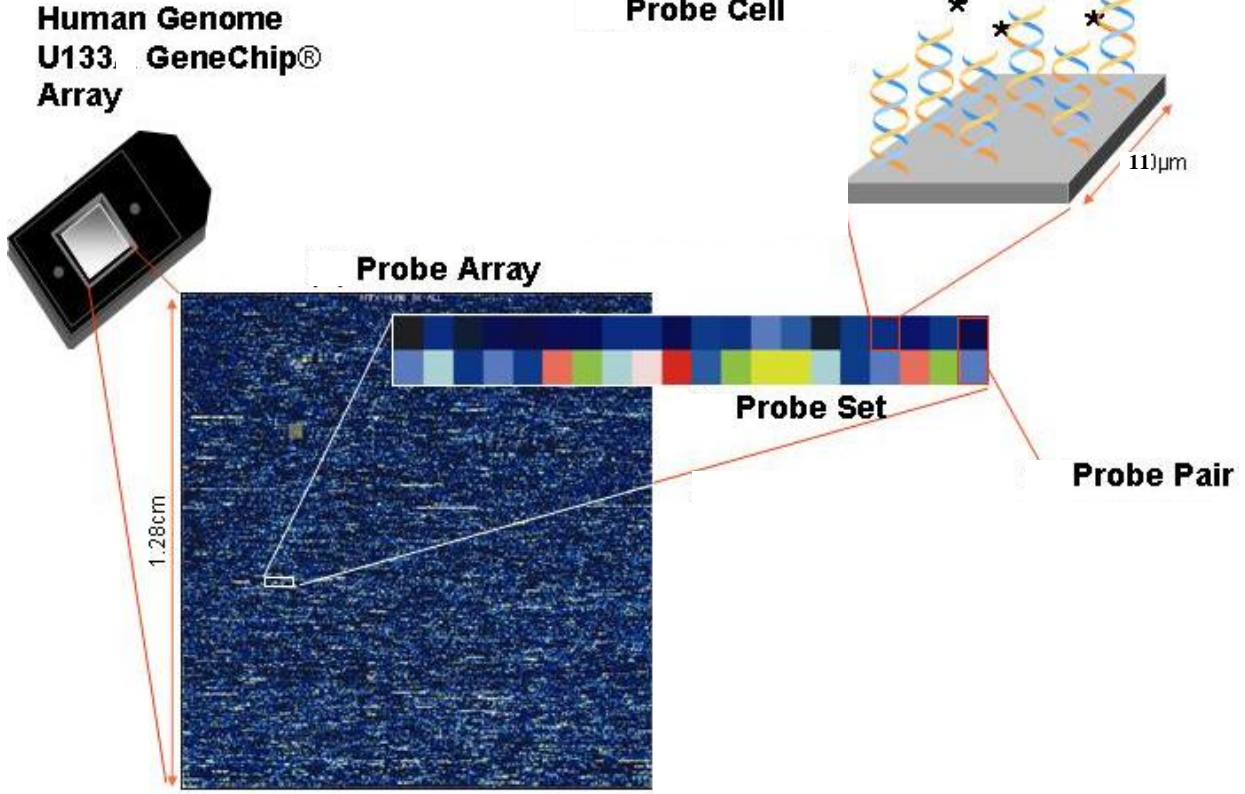

Figura 9: Diagrama ilustrativo do GeneChip® HGU133 plus 2. Divisões e dimensões do GeneChip Fonte: Lipshutz et al., 1999.

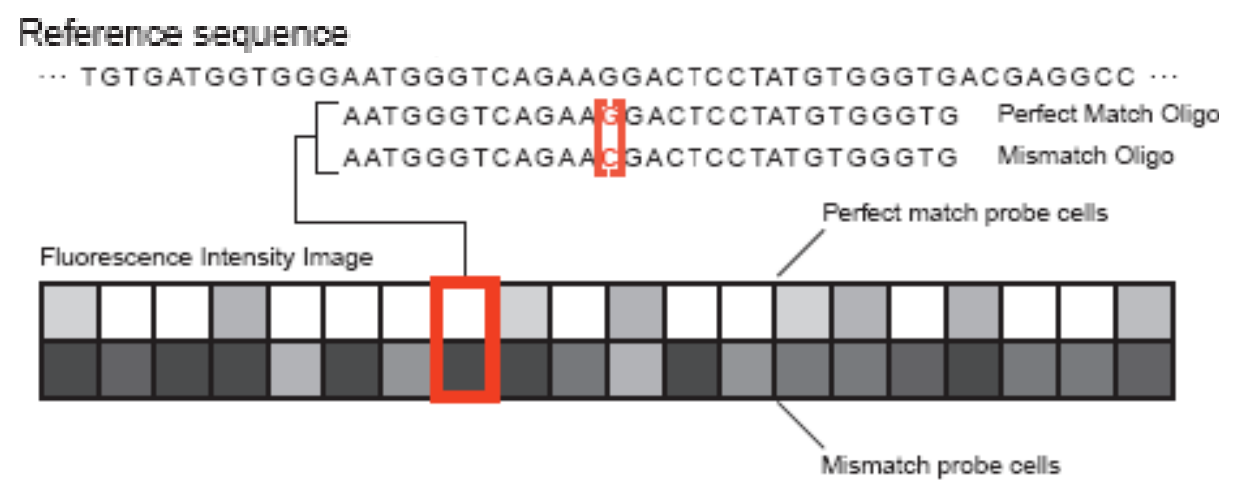

Figura 10: Desenho da construção de sequências nucleotídeas perfect match (PM) e mismatch (MM) Fonte: Lipshutz et al., 1999.

O leitor detecta a intensidade da fluorescência de cada probe cell gerando arquivos contendo a imagem de todas as probes cell (dat file) e os valores das intensidades correspondentes (cel file) através do método de gradeamento global e feature extration. Os arquivos contendo estes dados 
(imagem e intensidade) podem ser analisados por qualquer programa específico que possua algoritmos para análise de grupos sondas (Probe Set Algorithms) (Seo e Hoffman, 2006).

3.7.1.2 Correção do sinal de fundo (Background): A correção do background é o principal passo para remoção de contribuições não biológicas ao sinal medido. Típicos exemplos de sinais não especificos são o sinais de fundo das lavagens incompletas, ligações inepecíficas de transcritos, entre outros. (Seo e Hoffman, 2006).

3.7.1.3 Normalização: Após a obtenção dos dados e eliminação de valores espúrios em decorrência de possíveis problemas na fixação das sondas, marcação das amostras, hibridização etc., um ajuste geral dos dados é necessário antes de uma análise estatística mais formal. Este processo de correção dos dados é denominado normalização, e considera ajustes para diferenças entre chips (em termos de média ou mediana e variância), efeito de marcação e outros possíveis erros sistemáticos. Alguns procedimentos de normalização baseiam-se em somente alguns genes presentes nos chips (como genes controles ou housekeeping e genes com expressão supostamente constante nos diversos grupos experimentais), outros baseiam-se em todos os genes e utilizam procedimentos estatísticos robustos, com a suposição de que a maioria dos genes é não diferencialmente expressa entre os grupos experimentais (Göhlmann e Talloen, 2009). 
Dentre os diferentes algorítimos disponiveis é frequente o uso do RMA (Robust Multi-array Average; proposto por Irizarry et al., 2003). O algoritmo RMA adota um procedimento denominado normalização quantílica, permitindo que todos os chips apresentem mesma distribuição empírica dos valores de intensidade, de maneira em que são coincidentes nos termos de locação (incluindo medidas de centralidade e percentis) e escala ou variabilidade. Esta abordagem aumenta a sensibilidade a pequenas mudanças entre as amostras controle e as amostras testadas, além de minimizar a variância sem compremeter as diferença absoluta na expressão valores (fold change) (Bolstad et al., 2003).

3.7.1.4 Sumarização: é a etapa onde os valores de intensidade observados para cada conjunto de sondas representativas dos genes (probe set) são combinados numa única medida resumo para determinar o nível de expressão do gene. Existem diferentes técnicas com diferente resultados, algumas técnicas (como MAS 5.0, GC-RMA e PLIER) utilizam a média das diferenças entre a intensidade das sondas perfect match PM e a intensidade das sondas mismatch - MM para produzir o valor de expressão, outras que consideram somente o valor da intensidade das sondas perfect match PM (como MBEI, RMA, sRMA, FARMS). As técnicas citadas são algoritmos contidos em programas específicos para análise de dados de microarray, um rápido resumo pode ser consultado em Seo e Hoffman, 2006. 


\subsubsection{Análises dos Dados}

Os dados gerados de microarray possuem utilidade somente se extrairmos informações significativas sobre o sistema estudado Analisar os dados da expressão global do genoma é uma tarefa crucial e a escolha da técnica estatística tem profundo impacto sobre as inferências elaboradas a partir do estudo. Análises adequadas podem descobrir padrões até agora não detectados, enquanto técnicas mal empregadas podem induzir em erro, deixando de ressaltar interessantes achados ou sugerindo resultados falsamente positivos (Slonim, 2002).

Uma limitação comum nas análises etatísticas de dados de microarray referese ao fato de que número de genes em cada chip (número de observações por amostra) serem extremamente maior do que o número de amostras (ou chips) no experimento. Desta maneira, as análises são conduzidas independentemente para cada gene (Göhlmann e Talloen, 2009).

Dado o pequeno tamanho amostral para cada gene, estimativas de componentes de variância são instáveis e o poder estatístico para se detectar diferenças entre os grupos experimentais é geralmente pequeno. Uma estratégia para se contornar este problema é a utilização de estimadores de "encolhimento" (shrinkage estimators) para os componentes de variância. Programas de determinação de genes diferencialmente espressos possuem estes estimadores. (S myth, 2004; Cui et al., 2005; Feng et al., 2006).

Outra limitação refere-se ao fato de múltiplos testes serem efetuados em cada experimento (um para cada gene), de maneira que um grande número de falsos positivos é esperado mesmo em situações nas quais não há qualquer expressão diferenciada entre os grupos experimentais (Göhlmann e Talloen, 2009). 
Considerando essas particularidades, os processos de análise de dados podem ser resumidos na Detecção de genes diferencialmente expressos (DEG), Filtragem de gene, Exploração não-supervisionada, Predição supervisionada e Análises de Vias (Göhlmann e Talloen, 2009).

3.7.2.1 Detecção de genes diferencialmente expressos (DEG): Um objetivo comum em estudos de microarray é identificar os genes que são diferencialmente expressos sob determinadas condições. Para este fim, algorítmos estimam a diferença de expressão entre as condições, e testam se as diferenças observadas são estatisticamente significantes. Este geralmente é feito gene-a-gene separadamente. Embora tal abordagem ignore a dependência onipresente entre os genes, é muito útil para extrair informações relevantes a partir da alta-dimensionalidade e complexidade dos dados microarray. Posteriormente, todos os testes separados podem ser agregados novamente para ranquear os genes com base na significância estatísticas e/ou diferença absoluta na expressão valores (Fold change).

3.7.2.2 Filtragem de gene: é o procedimento de remoção de genes que não têm chance de ser diferencialmente expresso ou predito, independentemente da hipótese ou problema de predição que seria abordado. É muito frutífero, uma vez que aumenta a sensibilidade das análises, mas ainda não é uma prática comum, pois faltam orientações claras para execução do procedimento sem que se corra o risco de excluir alguns genes potencialmente relevantes (Calza et al., 2007; Talloen et al., 2007). 
3.7.2.3 Exploração não-s upe rvisionada: Análise de dados não supervisionado ou descoberta padrão é usada para explorar a estrutura interna ou as relações em um conjunto de dados. Métodos não supervisionados são ferramentas exploratórias, e não uma técnica de inferência. Não são apropriados como uma ferramenta de inspeção visual para identificar genes diferencialmente expressos. Estas técnicas de aprendizado não-supervisionado são tipicamente multivariada, e pode ser subdivididas em duas classes principais (Butte, 2002): métodos de projeção multivariada (Principal component analysis - PCA, Corresondence factor analysis - CFA e Spectral map SPM) e os métodos de agrupamento. Os métodos de agrupamento podem ainda ser divididos em métodos de agrupamento hierárquico (encontram sucessivos grupos utilizando grupos previamente etabelecidos) e métodos de compartimentação (procuram minimizar a heterogeneidade dos grupos e/ou para maximizar a sua separação) (Rahnenführer, 2005). Os algoritmos de compartimentaçao mais comuns são k-médias, compartimentação em torno medoídes (PAM; a.k.a. k-medoids) (Kaufman e Rousseeuw, 1990) e mapas auto-organizáveis (Kohonen, 1990; Tamayo et al., 1999)

3.7.2.4 Predição supervisionada: Microarrays são úteis na descoberta de "assinaturas de genes" que podem predizer determinadas características indivíduais. Podem por exemplo, fornecer valiosos biomarcadores clínicos de doenças ou de sensibilidade a tratamentos. Para extrair tais assinaturas moleculares dos dados, o principal objetivo é selecionar um número pequeno de características (genes) com alta acurâcia de predição (Díaz- 
Uriarte, 2006). Métodos de classificação combinados com métodos de seleção são utilizados para esse fim. Existe uma grande variedade de algoritmos de classificação que foram desenvolvidas em diferentes campos de pesquisa, como estatística, mineração de dados e aprendizado de máquina. Alguns dos métodos mais populares para os dados de microarrays são: Análise discriminante, Classificador vizinho mais próximo $(\mathrm{k}-\mathrm{NN})$, Regressão logística, Redes neurais, Arvores de classificação, Análise de predição para microarrays (PAM), Máquinas de Vetores Suporte (SVM)

3.7.2.5 Análises de Vias: A comparação dos padrões de expressão gênica entre grupos experimentais não se limita à geração de uma lista de genes diferencialmente expressos, obtidos a partir de testes de significância. Procedimentos complementares de análise permitem uma vizualização geral sobre os padrões nos dados. Por exemplo, os genes podem ser classificados em termos de processos metabólicos ou grupos ontológicos (gene ontology) mostrando as relações entre os genes super-regulados ou suprimidos em diferentes vias funcionais das células estudadas (Göhlmann e Talloen, 2009). 
MÉTODOS 


\section{MÉTODOS}

\subsection{Casuística}

Foram selecionados 16 pacientes em acompanhamento no Ambulatório de Imunodeficiências (ADEE 3002) do Departamento de Dermatologia do HC/FMUSP com as seguintes características: ser maior de 18 anos, estarem cronicamente infectados pelo HIV-1 e sem uso de terapia antiretroviral, apresentando contagem de células $\mathrm{TCD}^{+}$acima de 350 células $/ \mathrm{mm}^{3}$ e carga viral plasmática (CV) sem variações significativas* nos últimos 6 meses (* 25\% do número absoluto de células $\mathrm{TCD}^{+}$e $\left.\mathrm{CV} \geq 0,5 \log \right)$.

Foram excluídos também os pacientes com neoplasias ou infecções oportunistas até seis meses antes; doenças autoimunes; imunodeficiências primárias e deficiência na capacidade intelectual, que dificultavam o entendimento do termo de consentimento livre e esclarecido, previsto na resolução no. 196/96 do Ministério da Saúde, sobre pesquisa envolvendo seres humanos.

\subsection{Isolamento e Expansão Viral}

$\mathrm{O}$ isolamento e expansão do HIV foi realizado com amostras de pacientes infectados segundo o protocolo modificado da ACTG Laboratory Technologist Committe (http://www.niaid.nih.gov/Daids/vir_manual/full_vir_manual.pdf). 


\subsubsection{Separação de células mononucleares infectadas para isolamento viral.}

Foram coletados assepticamente em tubos heparinizados aproximadamente 10 $\mathrm{mL}$ de sangue periférico dos pacientes selecionados. Após a coleta o sangue foi diluído em salina estéril na proporção de 1:1 e fracionado pelo diferenciador de gradiente Ficoll-Hypaque, densidade 1077, através de centrifugação a 850 x g por 20 minutos em centrífuga Beckman Coulter. As células mononucleares do sangue periférico (PBMCs), localizadas na interface entre o Ficoll e o sobrenadante foram recolhidas, centrifugadas por 2 vezes em meio de cultura Roswell Park Memorial Institute (RPMI) a 420 x g por 10 minutos e quantificadas em contador automático Cell-Dyn 1300 Abbott .

\subsubsection{Depleção de linfócitos $\mathrm{TCD8}^{+}$}

As PBMCs de pacientes que apresentaram carga viral abaixo de $\leq 40.000$ cópias tiveram sua população de linfócitos $\mathrm{TCD}^{+}$depletadas para evitar o efeito citolítico destas células na cultura. Para tanto, após a separação por gradiente de Ficoll as PBMCs foram incubadas a $4^{\circ} \mathrm{C}$ por 15 minutos com microesferas conjugadas com anticorpos monoclonais anti-CD8 ${ }^{+}$(Miltenyi Biotech), e filtradas em colunas MS sob a ação do campo magnético do sistema de separação VARIOMACS (Miltenyi Biotech), para retenção de células $\mathrm{CD}^{+}$. As células eluídas, depletadas da fração $\mathrm{CD}^{+}$, foram então lavadas, ressuspendidas em meio de cultura RPMI e utilizadas no protocolo de expansão viral. 


\subsubsection{Separação e ativação de células mononucleares sadias para expansão viral}

Bolsas de Sangue recusadas em razão do baixo volume, lipêmicas ou nomeadas como "descarte por auto exclusão" que apresentaram sorologia negativa para HIV, sífilis, hepatite, doença de chagas, malária e HTLV, foram gentilmente doadas pela Associação Beneficente de Coleta de Sangue - Colsan/Unifesp para a separação de células mononucleares de doadores sadios.

Após a coleta, as bolsas foram selecionadas no setor de processamento do banco de Sangue do Hospital Municipal de Santo André "Mário Covas" e centrifugadas a $850 \mathrm{x}$ g por 5 minutos em centrífuga Beckman. Ao término da centrifugação três camadas foram visualizadas; o plasma, a fração leucocitária e a fração eritrocitária.

O sistema fechado de coleta em bolsa tripla com CPDA - 1 (citrato, fosfato, dextrose, adenina) permite que a camada superior com o plasma seja transferida por um extrator apropriado para uma segunda bolsa satélite, em seguida a camada intermediária com a fração leucocitária é transferida para terceira bolsa satélite, restando à fração eritrocitária na bolsa de coleta principal.

A bolsa satélite contendo a camada leucocitária (buffy coat) foi transportada à temperatura ambiente até o Laboratório de Investigação Médica 56 (LIM56) e manipulada em cabine de segurança biológica classe 2B segundo os critérios de biossegurança para material infectante. As PBMCs do buffy coat foram separadas por gradiente de Ficoll-Hypaque a 850g por 20 minutos e após duas lavagens com meio RPMI foram divididas em alíquotas de $1.10^{7}$ células e congeladas com uma solução de Soro Fetal Bovino (SFB) e 10\% Dimetilsulfóxido (DMSO) a $-80{ }^{\circ} \mathrm{C}$. Entre 24 a 
48 horas antes do uso, as alíquotas foram descongeladas e cultivadas em $5 \mathrm{~mL}$ de meio de cultura contendo $10 \%$ de SFB, $5 \mu \mathrm{g} / \mathrm{mL}$ de fitohemaglutinina (PHA) e 20 $\mathrm{UI} / \mathrm{mL}$ de IL-2 para promover a ativação.

\subsubsection{Expansão viral}

Cerca de $1.10^{7}$ PBMCs de paciente infectado e $1.10^{7}$ de PBMCs de doador sadio, previamente ativadas e lavadas para retirada da PHA, foram co-cultivadas em cerca de $5 \mathrm{~mL}$ de meio de cultura RPMI contendo $10 \%$ de SFB e IL-2 (20 UI/mL) a $37^{\circ} \mathrm{C}$ em estufa de $\mathrm{CO}_{2}(5 \%)$. O meio de cultura foi trocado a cada 3 dias e semanalmente as culturas foram realimentadas com $1.10^{7}$ PBMCs previamente ativadas de doadores sadios, durante aproximadamente 8 semanas.

\subsubsection{Inativação viral}

Para a inativação de vírus obtidos por expansão em PBMCs de doador sadio, foi utilizado protocolo descrito por Rossio e colaboradores (1998) com algumas modificações. O volume total de sobrenadantes obtidos das culturas de expansão viral foi incubado com $250 \mu \mathrm{M}$ de Aldrithriol-2 (AT-2 Sigma) com agitação constante, por 1 hora a $37^{\circ} \mathrm{C}$.

Após a inativação, o material foi centrifugado a 3.000 x g for 20 minutos para remoção de debris celulares e, a seguir, concentrado em dispositivo de ultrafiltração Amicon (Millipore) com membrana de $100 \mathrm{kDa}$, através de centrifugação a 1600 x g por 20 minutos. Após a concentração de todo o volume o material foi recolhido e lavado 2 vezes em PBS estéril para remoção do Aldrithriol-2.

A purificação dos vírus foi realizada por ultracentrifugação em centrífuga 
L80 Beckman, utilizando rotor de ângulo móvel (SW41 Ti). Para tanto, o material foi acondicionado sobre solução de sacarose $20 \%$ em TNE (20 mM de Tris/HCl, 20 mM de $\mathrm{NaCl}$ e 2,5 mM de EDTA), na proporção de 1/3 de sacarose: 2/3 sobrenadante concentrado; e foi realizada centrifugação a $4^{\circ} \mathrm{C}$ por 1 hora a 100.000 x g. Após este período, todo o material acima da sacarose foi removido e o pellet ressuspendido. Procedeu-se à nova centrifugação por mais 1 hora a 100.000 x g e em seguida o pellet foi ressuspendido em meio de cultura RPMI e quantificado com relação ao número de partículas virais através da reação de cadeia de polimerase (PCR).

Vale salientar que as etapas de isolamento, expansão e inativação estão sendo realizadas segundo as normas de biossegurança e em laboratório nível 3, cujo acesso tem sido gentilmente cedido pelo Laboratório de Virologia do Instituto de Medicina Tropical (IMT-USP) através do Prof. Dr. Cláudio Panutti.

\subsection{Detecção por ELISA do antígeno p24}

Este ensaio foi realizado com o kit Vironostika ${ }^{\circledR}$ HIV-1 Antigen da BioMérieux em dois momentos distintos; inicialmente com o objetivo de confirmar a expansão do vírus em culturas celulares, monitoradas semanalmente para detecção do antígeno p24 no sobrenadante, e posteriormente como marcador para avaliação da inativação viral com AT-2.

Em resumo, $100 \mu \mathrm{L}$ das amostras do sobrenadante da culturas virais foram incubadas em poços de placas de ELIS A previamente sensibilizadas com anticorpo anti-p24 do HIV, e em seguida tratadas com tampão de lise para exposição do core viral. Para o controle da reação foi utilizado poço contendo somente sobrenadante de cultura (controle negativo) ou controle positivo contendo $160 \mathrm{pg} / \mathrm{mL}$ de $\mathrm{p} 24$. Quando 
necessário a curva-padrão foi determinada através da diluição seriada de concentrações conhecidas da proteína p24, que variou entre 80 e 5 pg/mL. Após incubação por 2 horas as placas foram lavadas 4 vezes e incubadas por 1 hora a $37^{\circ} \mathrm{C}$ com $100 \mu \mathrm{L}$ de anticorpo humano anti-HIV-1 conjugado à peroxidase. Após novo ciclo de lavagem a placa foi incubada por mais 30 minutos com substrato cromogênico 3,3ф,5,5ф-Tetramethylbenzidine (TMB) e a reação bloqueada com ácido sulfúrico.

A leitura da absorbância foi realizada a $450 \mathrm{~nm}$ e a determinação da concentração protéica foi realizada utilizando-se o programa SoftMaxPro 5.1 (Bucher Biotec $A G)$.

\subsection{Geração de células dendríticas de rivadas de monó citos (Mo-DCs)}

Para a diferenciação de células dendríticas a partir de monócitos de sangue periférico foram coletados aproximadamente $40 \mathrm{~mL}$ de sangue em tubos heparinizados. Após a coleta o sangue foi diluído em salina isotônica na proporção de 1:1, separado em gradiente de Ficoll-hypaque (Sigma) por centrifugação a 850 x g por 20 minutos. Em seguida, as PBMCs foram incubadas a $4^{\circ} \mathrm{C}$ por 15 minutos com microesferas conjugadas com anticorpos monoclonais anti-CD14 (Miltenyi Biotech), para isolamento de monócitos pela passagem através do sistema de separação magnética de células (VARIOMACS, Miltenyi Biotech). Após lavagem os monócitos obtidos foram cultivados em placas de culturas de 24 poços $\left(2.10^{6}\right.$ células por poço) a $37^{0} \mathrm{C}$ em $5 \%$ de $\mathrm{CO}_{2}$ por 6 dias em meio de cultura Adoptive Immunotherapy Media - AIM-V (Gibco) contendo $50 \mathrm{ng} / \mathrm{mL}$ de GM-CSF (R\&D Systems) e $50 \mathrm{ng} / \mathrm{mL}$ de IL4 (R\&D Systems) para obtenção de Mo-DCs imaturas. 


\subsection{Pulso e Ativação das Mo-DCs}

Após 6 dias em cultura as Mo-DCs foram pulsadas, isto é, expostas ao HIV inativado por $2 \mathrm{hs}$ e posteriormente ativadas com citocinas pró-inflamatórias (IL-6, IL- $1 \beta$, IFN- $\alpha$ ) por $48 \mathrm{hs}$ em meio de cultura Adoptive Immunotherapy Media - AIMV (Gibco) contendo $50 \mathrm{ng} / \mathrm{mL}$ de GM-CSF (R\&D Systems) e $50 \mathrm{ng} / \mathrm{mL}$ de IL-4 ( $R \& D$ Systems) para obtenção de Mo-DCs maduras.

\subsection{Ca racterização fenotípica das células dendríticas.}

As Mo-DCs diferenciadas foram analisadas com relação à expressão de moléculas de superfície por citometria de fluxo. As células foram ressuspendidas em tampão fosfato salino (PBS) contendo $5 \%$ de SFB e distribuídas em tubos de citometria à concentração de $1.10^{5}$ células/tubo em $100 \mu \mathrm{L}$ de tampão. Em seguida os anticorpos conjugados a fluorocromos Isotiocianato de Fluoresceína (FITC), Ficoeritrina (PE) ou Ficoeritrina Cianina 5 (PECy5) (Pharmingen), específicos para $\mathrm{CD}_{11} \mathrm{c}^{+}$(marcadores de células dendríticas mielóides), CD14 ${ }^{-}$(marcador de linhagem monocítica, ausente em células dendríticas), HLA-DR (molécula apresentadora de antígenos em células humanas), foram adicionados aos tubos e incubados por 30 minutos a $4^{\circ} \mathrm{C}$ no escuro. Após este período as células foram lavadas 2 vezes e ressuspendidas em $200 \mu \mathrm{L}$ de PBS. As amostras foram então analisadas em citômetro de fluxo FACSCalibur, adquirindo-se no mínimo 10.000 eventos de uma população celular determinada segundo suas características de tamanho e granulosidade, excluindo-se a região de linfócitos e células mortas. 


\subsection{Avaliação quali-quantitativa do RNA extraído}

O RNA total foi extraído de células dendríticas derivadas de monócitos (MoDCs), em três momentos consecutivos utilizando RNeasy Micro Kit (Quiagen). A primeira extração ocorreu no momento antecedente ao estímulo viral ou pré-pulso (T0), seguidos pela segunda extração após duas horas com estímulo viral ou póspulso (T1) e a terceira extração após 48 horas em presença de citocinas próinflamatórias ou pós-pulso ativado (T2).

T0

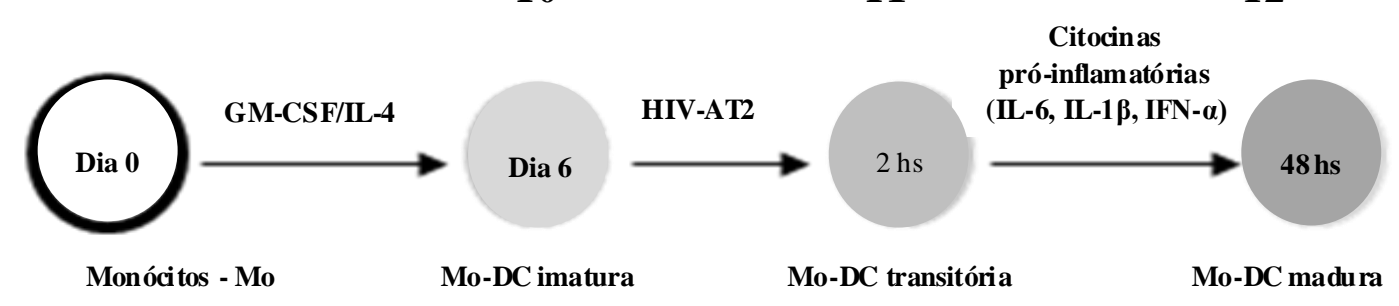

Figura 11. Esquema de extração de RNA nos três momentos da cultura celular.

As células foram centrifugadas $300 \times \mathrm{x}$ por 5 minutos para retirada do meio de cultura e lisadas com tampão denaturante de isotiocianato de guanidina. Após a passagem por uma coluna de homogeneização (QIAshredder) e o acréscimo de etanol 70\% a amostra, aplicada na coluna de extração de sílica RNeasy microspin e submetida a centrifugações sucessivas. Opcionalmente durante o processo de extração o kit fornece uma solução digestora de Dnase para proteção do material extraído contra degradação enzimática. O RNA foi eluído em $15 \mu \mathrm{L}$ de água ultra pura livre d Rnases. 


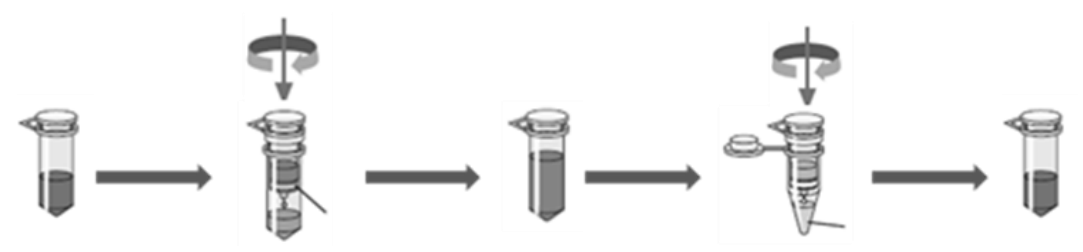

Lise celular Col. Homogenização Etanol 70\% Col. de Extração RNA eluído

Figura 12. Esquema de extração de RNA da cultura celular.

A determinação da concentração e da pureza do RNA extraído foi estabelecida pela análise espectrofotométrica de $2 \mu \mathrm{L}$ de amostra em espectrofotômetro Nanodrop ND-1000 e por corrida eletroforética em gel nativo de agarose $2 \%$ com tampão Tris-Borato (TBE) 1x.

\subsection{Ensaio de Microarranjo (Microarrays)}

O RNA armazenado a $-70 \mathrm{C}$ foi descongelado e o processo de síntese de cDNA, marcação e hibridização em lâminas de microarrays ou simplesmente arrays do tipo GeneChip ${ }^{\circledR}$ HU133 Plus 2.0, foi realizado segundo o protocolo padrão da Affymetrix para dois ciclos de amplificação (Two Cycle Protocol) o qual, resumidamente, consiste em:

Amplificação e Marcação do RNA: As amostras de RNA total foram submetidas à reação de transcrição reversa para síntese de cDNA, adicionando-se oligonucleotídeos dT e T7-primers, seguida por uma reação de transcrição in vitro (IVT) para marcação com Biotina intercalante (biotinilação) e fragmentação do cRNA marcado.

Hibridização, lavagem e leitura: O cRNA marcado juntamente com coquetel de hibridização, contendo sondas controle e o marcador fluorescente ficoeritrina 
(complexo SAPE), foram introduzidos nos chips de DNA, e após as etapas de incubação e lavagem, foram lidos por um escâner apropriado, fornecendo os primeiros dados experimentais definidos pela intensidade dos sinais detectados.
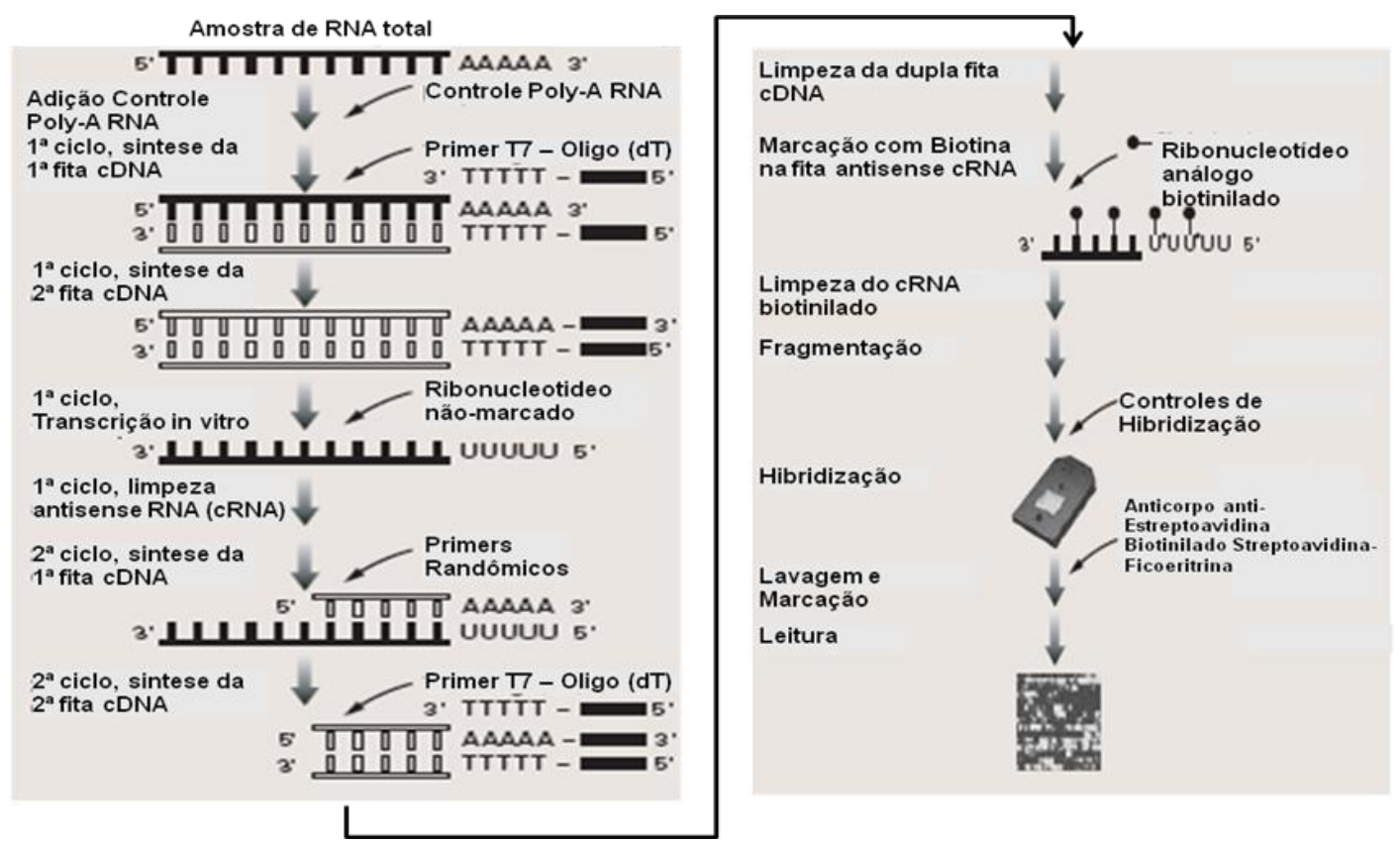

Figura 13. Esquema do protocolo de amplificação em dois ciclos. Fonte: Modificado do Affymetrix Expression Analysis Technical Manual 2006 Affymetrix

\subsection{Análises dos dados de microrrays:}

Considerando a etapa de pré-processamento, utilizamos o algoritmo RMA (Robust Multi-array Average), para a correção do sinal de fundo (background), normalização dos dados e sumarização das intensidades. O algoritmo encontra-se disponível no programa Expression Console ${ }^{\circledR}$ versão 1.1 da plataforma Affymetrix ou no pacote Affy do projeto Bioconductor (http://www.bioconductor.org).

$\mathrm{Na}$ etapa da análise de dados empregamos ferramentas relativas aos testes de significância, análise discriminante e análise de vias e funções. Utilizamos os pacotes 
LIMMA (Linear Models for Microarray Analysis), que emprega uma combinação de modelo linear com o método de Bayes empírico (Smyth, 2005) e RankProd (Rank Product Non-Parametric Method) teste não-parametrico, para identificação dos gene diferencialmente expressos (Breitling et al., 2004; Hong et al., 2006).

A motivação para utilizar dois métodos de análise que processam de forma distintas os dados é justificada pelo aumento da confiabilidade na seleção dos genes estatisticamente significativos. O significado biológico e vias funcionais dos genes diferencialmene expressos foram determinadas pelo programa Ingenuity Pathways Analysis (Ingenuity ${ }^{\circledR}$ Systems, www.ingenuity.com). 
RESULTADOS 


\section{RESULTADOS}

\subsection{Isolamento, expansão e inativação do HIV}

Realizamos o processo de isolamento viral em 16 pacientes cronicamente infectados pelo HIV-1 e somente 9 pacientes (tabela 1) completaram todas as etapas do processo. Foram excluídos 3 pacientes por ter iniciado a terapia ARV logo após o início do ensaio de isolamento, outros 3 pacientes não retornaram ao ambulatório e 1 paciente não apresentou positividade para antígeno p24 após 4 semanas consecutivas de cultivo.

Tabela 2. Resumo dos dados dos pacientes selecionados para o estudo

\begin{tabular}{|c|c|c|c|c|c|c|c|}
\hline $\begin{array}{c}\text { Paciente } \\
\mathrm{N}^{\mathbf{0}}\end{array}$ & Coleta & Gênero & CD4 & $\mathrm{CV}$ & $\begin{array}{c}\text { Resultado da } \\
\text { Cultura }\end{array}$ & $\begin{array}{l}\text { Uso de } \\
\text { ARV }\end{array}$ & $\begin{array}{c}\text { Situação do paciente no } \\
\text { estudo }\end{array}$ \\
\hline 01 & $14 / 03 / 2008$ & $\mathrm{~F}$ & 560 & $<400$ & neg & não & Excluído \\
\hline 02 & $29 / 01 / 2008$ & $\mathrm{~F}$ & 1032 & 10.000 & pos & - & Excluído \\
\hline 03 & $27 / 07 / 2009$ & $\mathrm{~F}$ & 600 & 30.000 & pos & não & Ensaio concluido \\
\hline 06 & $06 / 12 / 2007$ & $\mathrm{~F}$ & 679 & 118.000 & pos & $\operatorname{sim}$ & Excluído \\
\hline 08 & $15 / 05 / 2008$ & M & 534 & 21.189 & pos & não & Ensaio concluido \\
\hline 09 & $16 / 08 / 2007$ & M & 524 & 161.000 & pos & $\operatorname{sim}$ & Excluído \\
\hline 10 & $27 / 07 / 2009$ & $\mathrm{~F}$ & 600 & 40.000 & pos & não & Ensaio concluido \\
\hline 11 & $06 / 03 / 2008$ & $\mathrm{~F}$ & 665 & 24.800 & pos & não & Ensaio concluido \\
\hline 12 & $06 / 03 / 2008$ & $\mathrm{~F}$ & 855 & 95.400 & pos & não & Ensaio concluido \\
\hline 14 & $28 / 08 / 2007$ & M & 921 & 145.000 & pos & não & Ensaio concluido \\
\hline 15 & $23 / 04 / 2007$ & M & 414 & 113.000 & pos & - & Excluído \\
\hline 16 & $08 / 05 / 2007$ & $\mathrm{~F}$ & 928 & 43.300 & pos & $\operatorname{sim}$ & Excluído \\
\hline 17 & $08 / 05 / 2007$ & M & 413 & 53.300 & pos & - & Excluído \\
\hline 18 & $29 / 01 / 2008$ & M & 494 & 36.851 & pos & não & Ensaio concluido \\
\hline 19 & $16 / 04 / 2008$ & $\mathrm{~F}$ & 561 & 33.700 & pos & não & Ensaio concluido \\
\hline 38 & $24 / 11 / 2009$ & M & 600 & 40.000 & pos & não & Ensaio concluido \\
\hline
\end{tabular}

CV: Carga Viral ; ARV: Anti-retroviral 


\subsection{Diferenciação de Monócitos em Células Dendríticas}

Executamos com as células dendríticas dos indivíduos controles (C1 e C2) e dos pacientes (P08, P11, P12, P14, P18 e P19) a caracterização fenotípica da diferenciação celular, avaliando a expressão de marcadores de superfície CD11c, CD14 e HLA-DR em citometria de fluxo após 6 dias de cultura. Encontramos, tanto nos indivíduos controles quanto nos pacientes, a supressão de CD14 (marcador de células monocíticas) e a expressão de CD11c e HLA-DR em 95\% das células, indicando sucesso na diferenciação com a predominância de células dendríticas.

a.

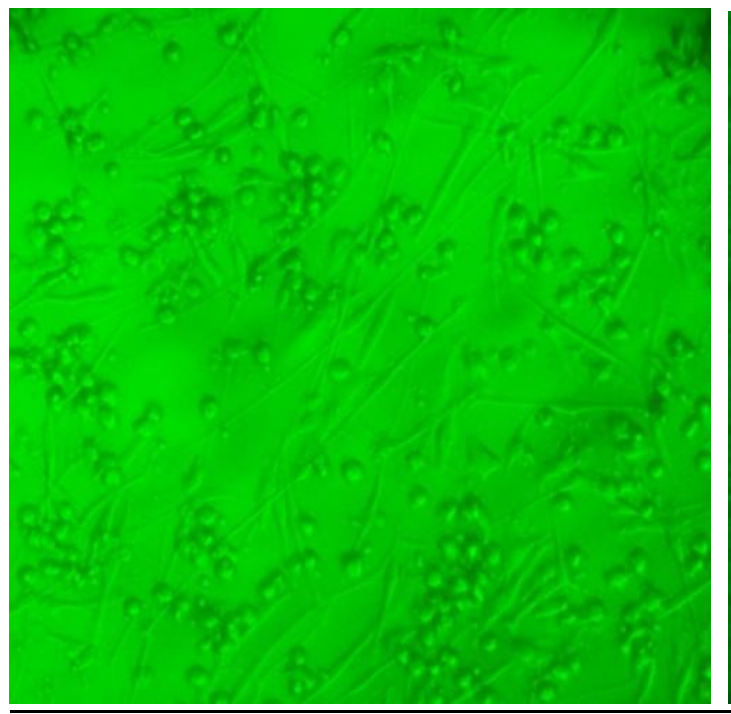

b.

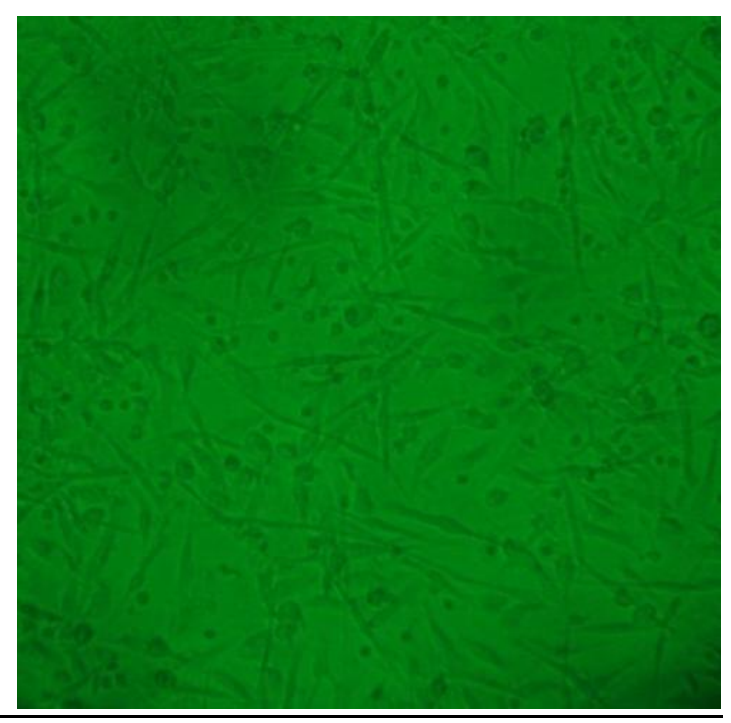

Figura 14. Microscopia óptica de células dendríticas derivadas de monócitos a. Nota-se as células arredondadas com poucos dendritos característico do estado imaturo. b. Observa-se nas células a presença dos dendritos característicos. 


\subsection{Citometria de Fluxo}

\section{Controle 1}

A.

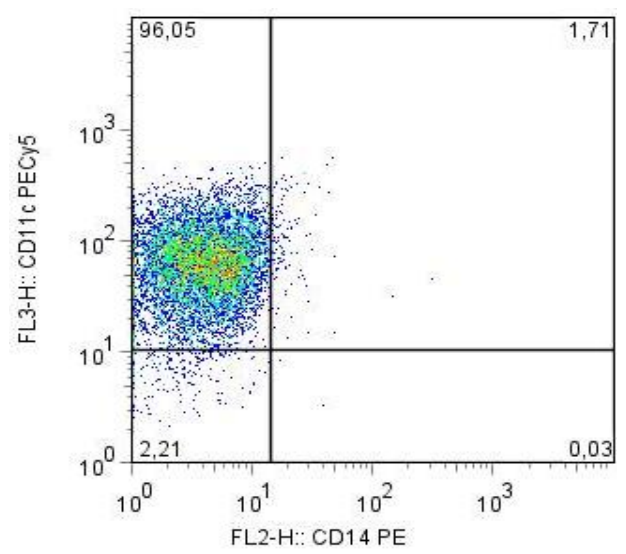

B.

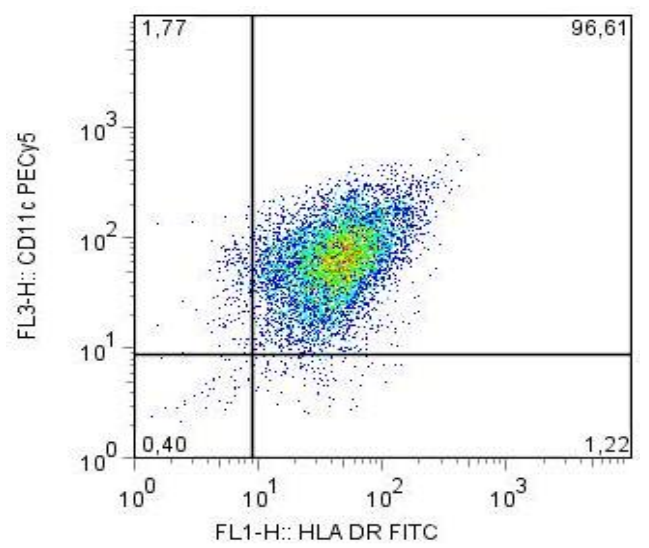

Figura 15. Perfil fenotípico de Mo-DC de indivíduos sadios - controle 1. A) Nota-se a predominância da população celular com expressão de CD11c 96,05\% e ausência da expressão de CD14 0,03\%; B) Presença da expressão de HLA-DR e CD11c 96,61 \% confirmando a predominância de células dendríticas;

\section{Controle 2}

A.

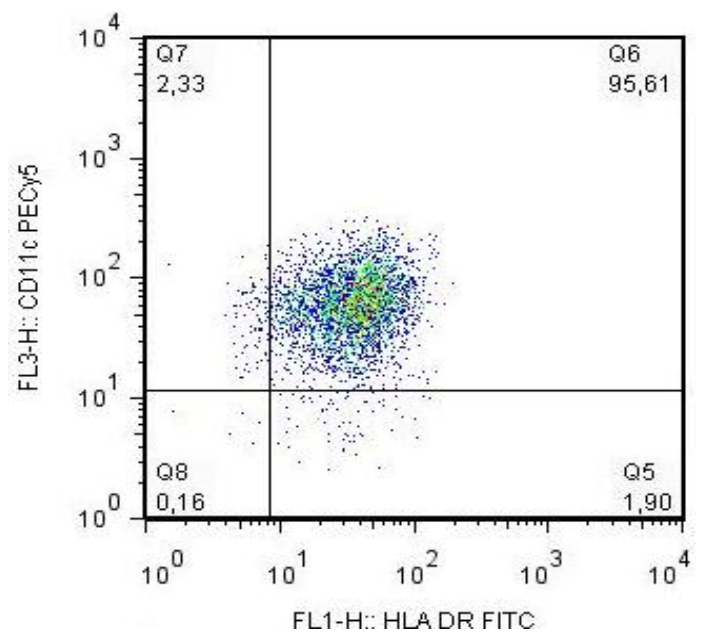

B.

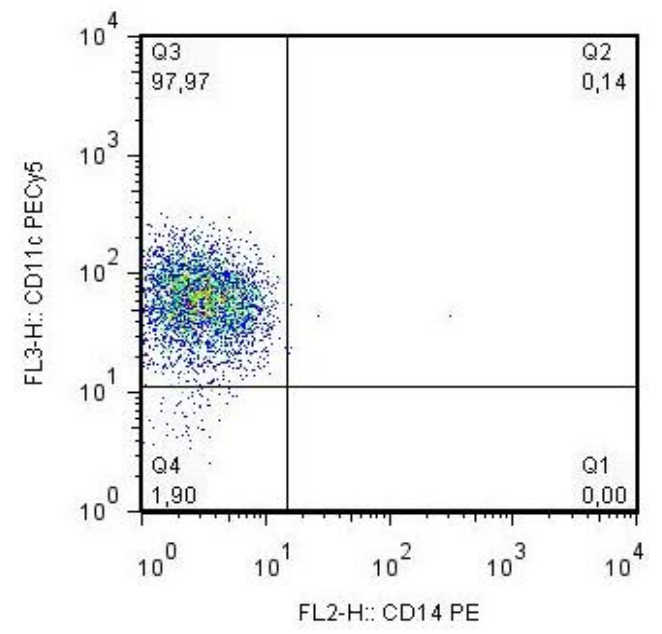

Figura 16. Perfil fenotípico de Mo-DC de indivíduos sadios - controle 2. A) Nota-se a predominância da população celular com expressão de CD11c 97,97\% e ausência da expressão de CD14; B) Presença da expressão de HLA-DR e CD11c 96,61 \% confirmando a predominância de células dendríticas; 
A.

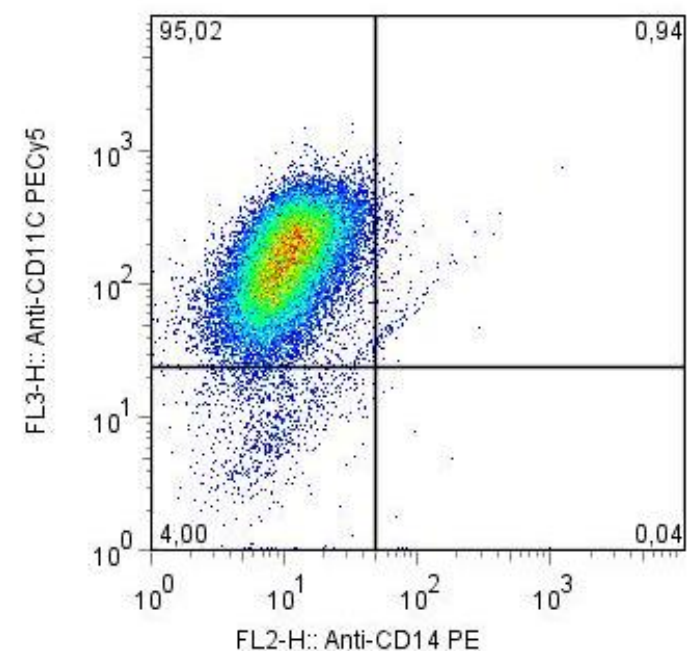

B.

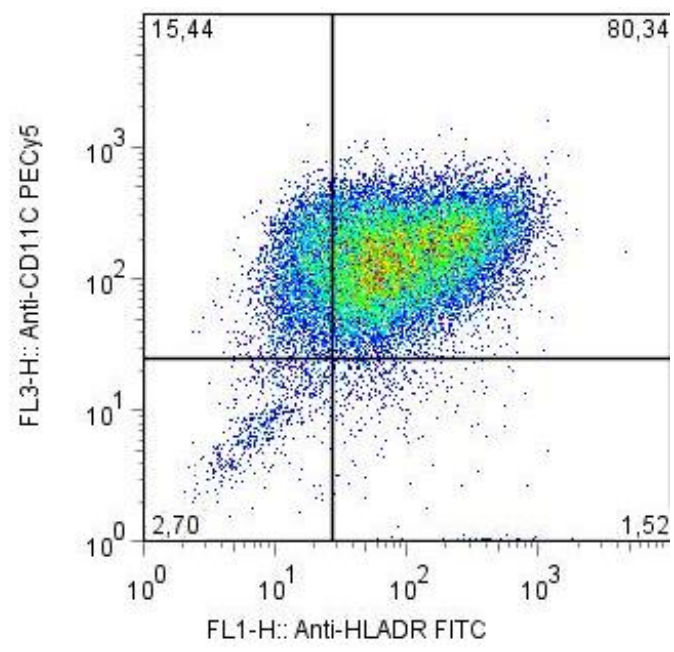

Figura 17. Perfil fenotípico Mo-DC do paciente n.8. A) Nota-se a predominância da população celular com expressão de CD11c 99,91\% e ausência da expressão de CD14; B) Presença da expressão de HLA-DR e CD11c 81,74 \% confirmando a predominância de células dendríticas;

A.

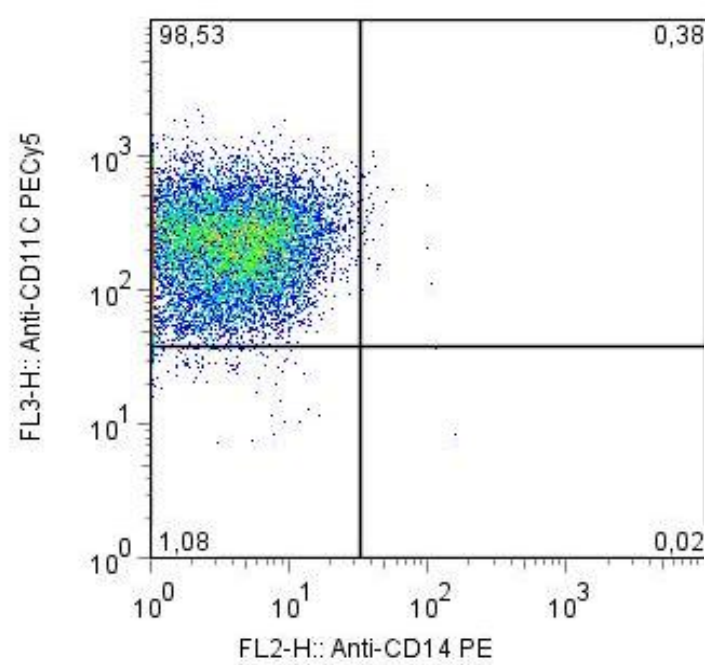

B.

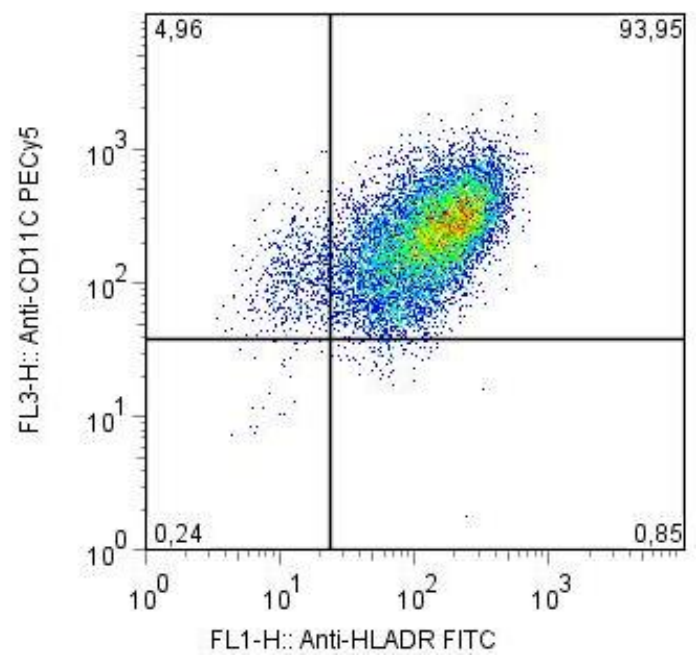

Figura 18. Perfil fenotípico Mo-DC do paciente n.11 A) Nota-se a predominância da população celular com expressão de CD11c 98,53\% e ausência da expressão de CD14; B) Presença da expressão de HLA-DR e CD11c 93,95 \% confirmando a predominância de células dendríticas; 
A.

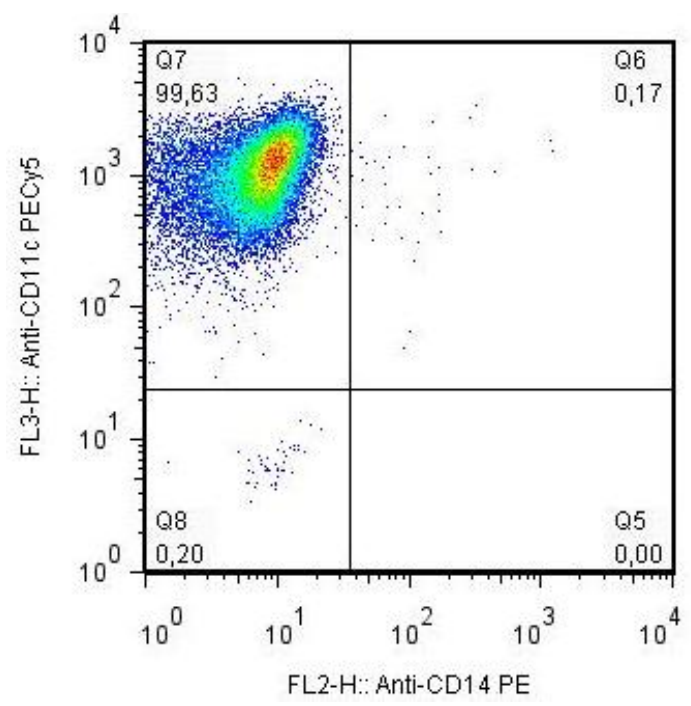

B.

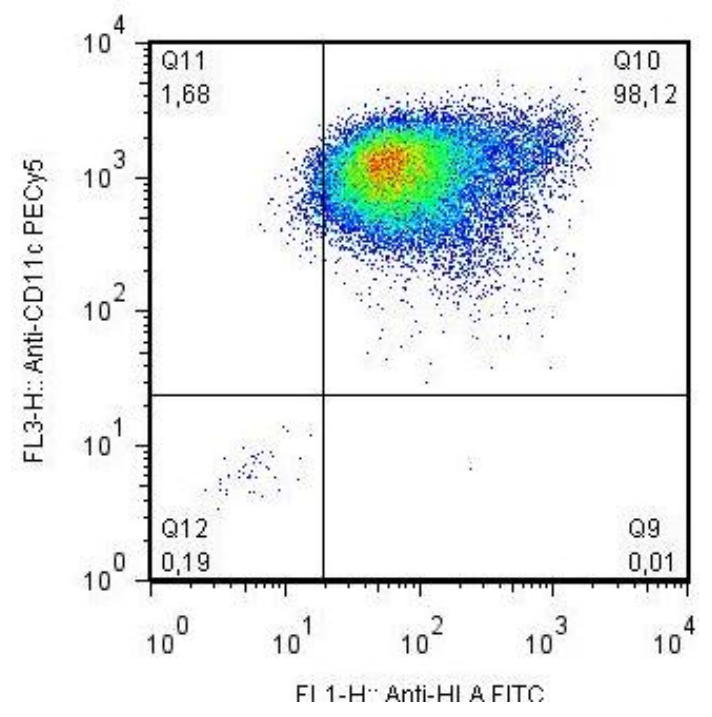

Figura 19. Perfil fenotípico Mo-DC do paciente n.12 A) Nota-se a predominância da população celular com expressão de CD11c 98,63\% e ausência da expressão de CD14; B) Presença da expressão de HLA-DR e CD11c 98,125 \% confirmando a predominância de células dendríticas;

A.

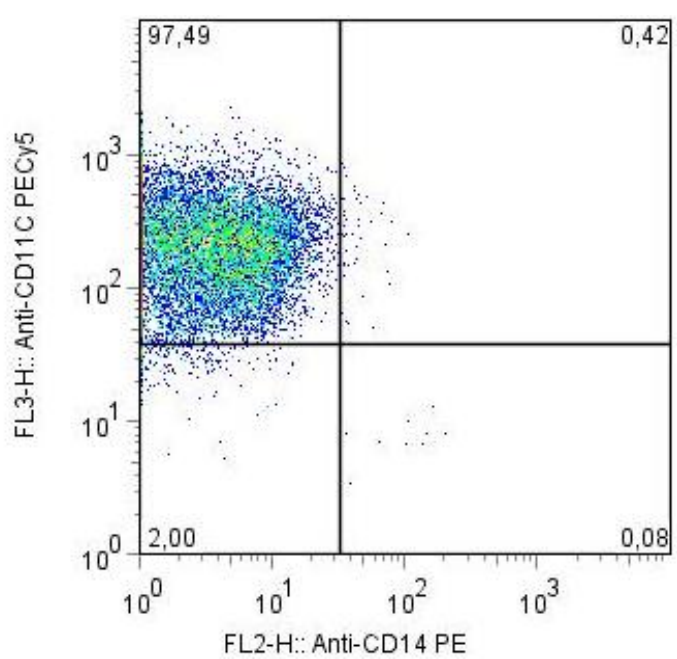

B.

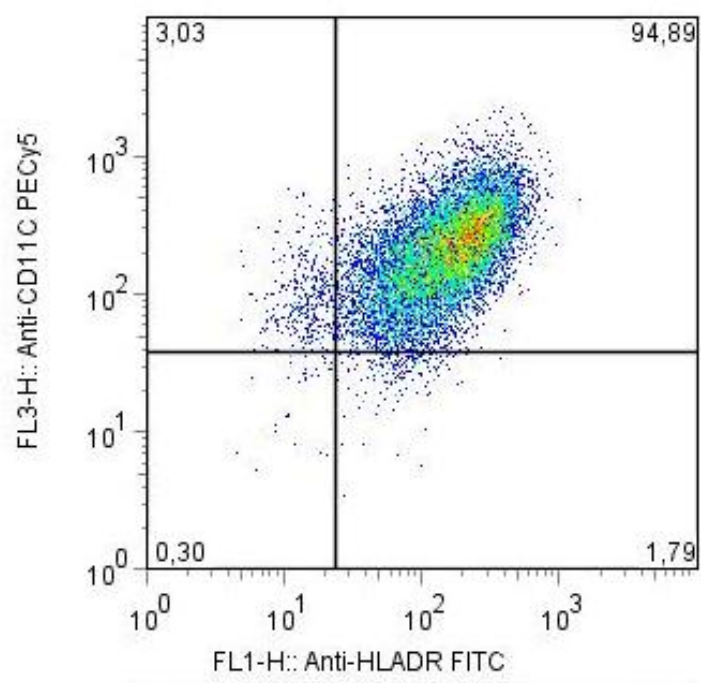

Figura 20. Perfil fenotípico Mo-DC do paciente n.14. A) Nota-se a predominância da população celular com expressão de CD11c 97,49\% e ausência da expressão de CD14; B) Presença da expressão de HLA-DR e CD11c 94,89 \% confirmando a predominância de células dendríticas; 


\subsection{Avaliação quali-quantitativa do RNA extraído}

Utilizamdo um kit específico para extrações de RNA em pequenas amostras $\left(0,5 \cdot 10^{6}\right.$ células), obtivemos o RNA das células células dendríticas dos doadores saudáveis e dos individuos infectados. A quantidade de RNA variou de acordo como número de células dendríticas disponíveis (entre $0,2.10^{6}$ a $0,8.10^{6}$ ) nos três momentos da extração.

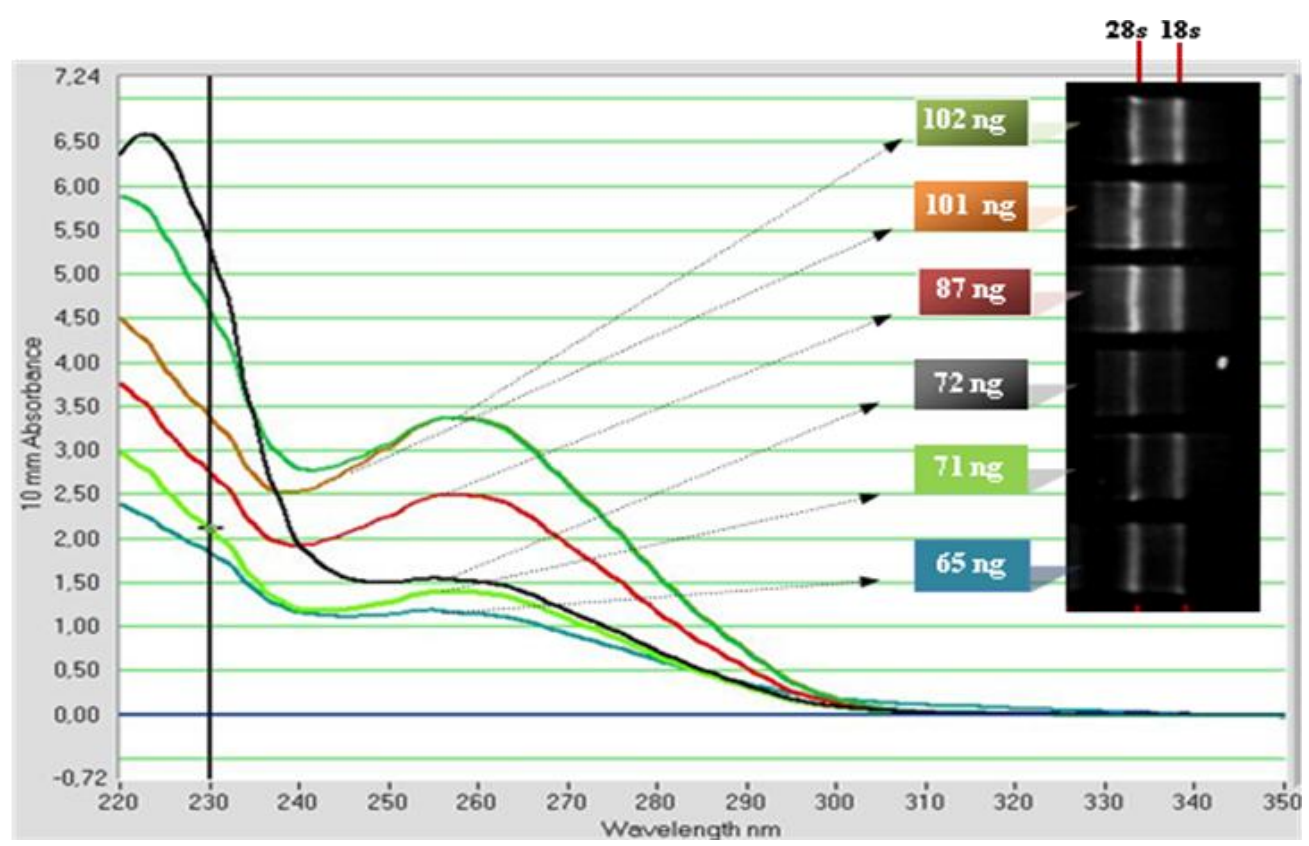

Figura 21. Perfil de avaliação do RNA das amostras dos indivíduos controle utilizando NanoDrop 1000 e eletroforese. Observa-se os espectros de onda do RNA possuem formato de "sino" com picos em $260 \mathrm{~nm}$, seguidos dos valores das concentrações e do sinal das bandas $28 \mathrm{~s}$ e $18 \mathrm{~s}$ da corrida eletroforética em gel nativo. Para concentração de C1 temos T0 $=71 \mathrm{ng} / \mu \mathrm{L}, \mathrm{T} 1=65 \mathrm{ng} / \mu \mathrm{L}$ e T2 $=102 \mathrm{ng} / \mu \mathrm{L}$, para C2 temos $\mathrm{T} 0=72 \mathrm{ng} / \mu \mathrm{L}, \mathrm{T} 1=101 \mathrm{ng} / \mu \mathrm{L}$ e T2 $=87 \mathrm{ng} / \mu \mathrm{L}$.

Semelhantemente, realizamos a quantificação do RNA de células dendríticas dos individuos infectados nos três momentos da extração. 


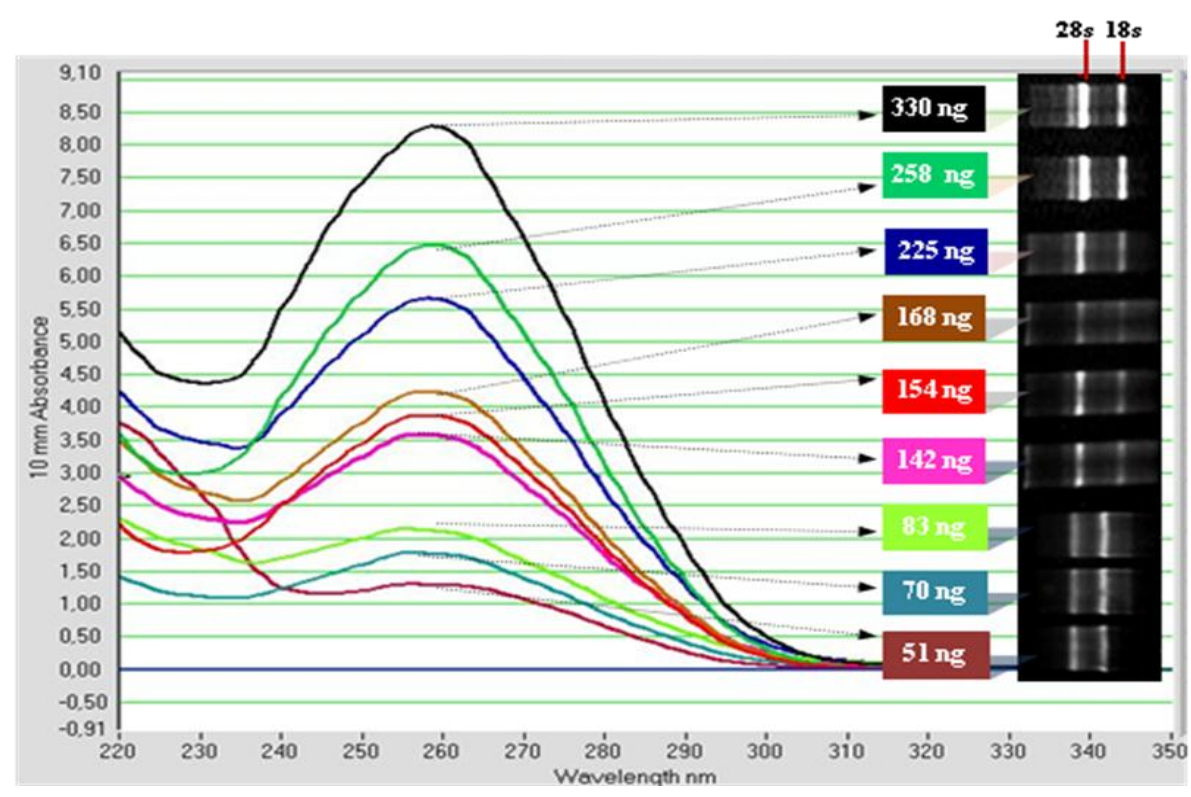

Figura 22. Perfil de avaliação do RNA das amostras dos pacientes. Observam-se os espectros de onda do RNA possuem formato de "sino" com picos em $260 \mathrm{~nm}$, seguidos dos valores das concentrações e do sinal das bandas $28 \mathrm{~s}$ e $18 \mathrm{~s}$ da corrida eletroforética em gel nativo. Para concentração de P08 temos T0 $=330 \mathrm{ng} / \mu \mathrm{L}, \mathrm{T} 1=258 \mathrm{ng} / \mu \mathrm{L}$ e T2 $=142 \mathrm{ng} / \mu \mathrm{L}$, para $\mathrm{P} 14$ temos $\mathrm{T} 0=168 \mathrm{ng} / \mu \mathrm{L}, \mathrm{T} 1=83 \mathrm{ng} / \mu \mathrm{L}$ e T2 $=51 \mathrm{ng} / \mu \mathrm{L}$ e para $\mathrm{P} 19$ temo $\mathrm{T} 0=225$ $\mathrm{ng} / \mu \mathrm{L}, \mathrm{T} 1=154 \mathrm{ng} / \mu \mathrm{L}$ e $\mathrm{T} 2=70 \mathrm{ng} / \mu \mathrm{L}$.

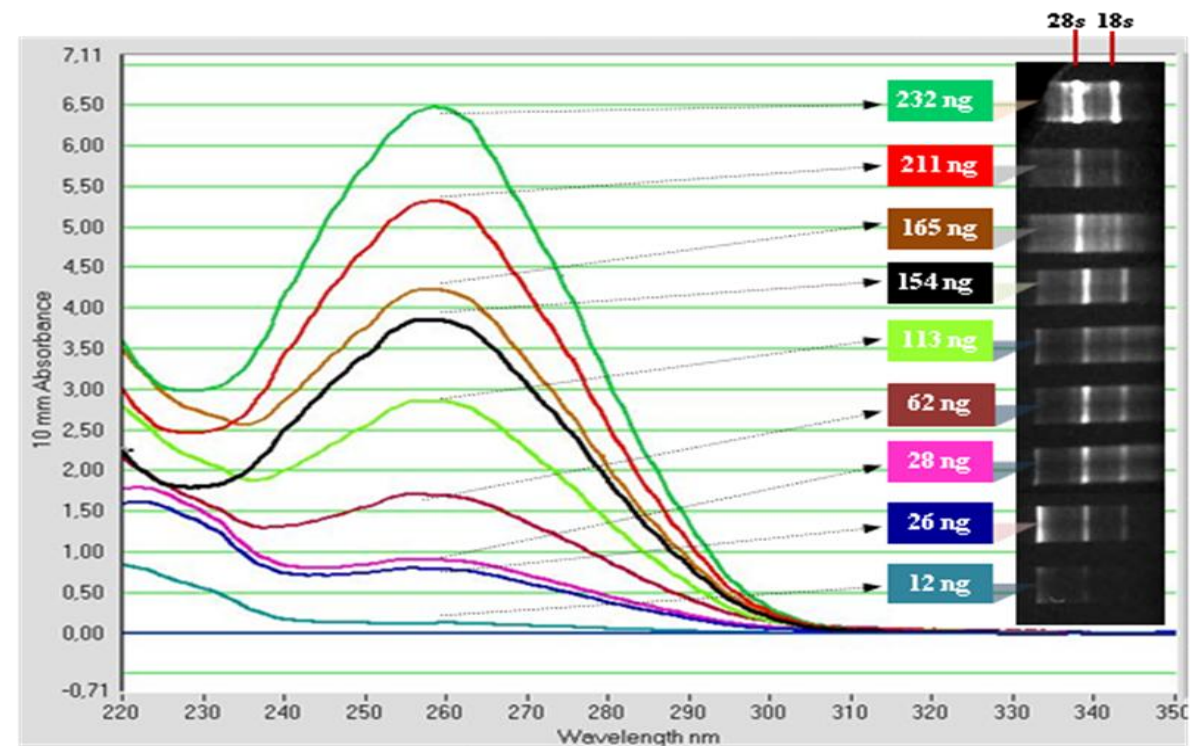

Figura 23. Composição do perfil de avaliação do RNA das amostras dos pacientes. Observam-se os espectros de onda do RNA possuem formato de "sino" com picos em 260 $\mathrm{nm}$, seguidos dos valores das concentrações e do sinal das bandas $28 \mathrm{~s}$ e $18 \mathrm{~s}$ da corrida eletroforética em gel nativo. Para concentração de $\mathrm{P} 11$ temos $\mathrm{T} 0=232 \mathrm{ng} / \mu \mathrm{L}, \mathrm{T} 1=154$ $\mathrm{ng} / \mu \mathrm{L}$ e T2 $=113 \mathrm{ng} / \mu \mathrm{L}$, para $\mathrm{P} 12$ temos T0 $=211 \mathrm{ng} / \mu \mathrm{L}, \mathrm{T} 1=165 \mathrm{ng} / \mu \mathrm{L}$ e $\mathrm{T} 2=62 \mathrm{ng} / \mu \mathrm{L}$ e para P18 temo T0 $=28 \mathrm{ng} / \mu \mathrm{L}, \mathrm{T} 1=26 \mathrm{ng} / \mu \mathrm{L}$ e T2 $=12 \mathrm{ng} / \mu \mathrm{L}$. 


\subsection{Ensaios de microarray}

Realizamos os ensaios com amostra de 2 indivíduos controles (C1 e C2) e 6 indivíduos infectados (P08, P11, P12, P14, P18 e P19) nos três momentos da cultura (T0, T1 e T2) totalizando 24 arrays. Executamos as etapas de amplificação, monitoramento do material amplificado e marcação no Laboratório de Investigação Médica 56 (LIM56), enquanto que as etapas de hibridização e leitura foram realizadas na plataforma Affymetrix da Associação Fundo de Incentivo à Psicofarmacologia (AFIP), entidade ligada a Universidade Federal de São Paulo (UNIFESP). Realizamos as análises de bioinformática em computadores configurados específicamente para análise de microarrays com os programas Expression Console ${ }^{\circledR}$ versão 1.1 (Affymetrix inc.), R com os pacotes Affy, LIMMA e RankProd (http://www.bioconductor.org) e programa Ingenuity Pathways Analys is (Ingenuity ${ }^{\circledR}$ Systems, www.ingenuity.com). 


\subsubsection{Métricas de Controle de Qualidade:}

\subsubsection{Inspeção visual}

Os arrays devem apresentar uma imagem padrão com parâmetros de referência definidos pelo fabricante. Parâmetros como oligos de borda - B2, nome do chip e controles de centro, são utilizados para direcionar o laser do escâner e alinhar a grade de visualização ( rid) do programa de captura de imagem (Figura 24)

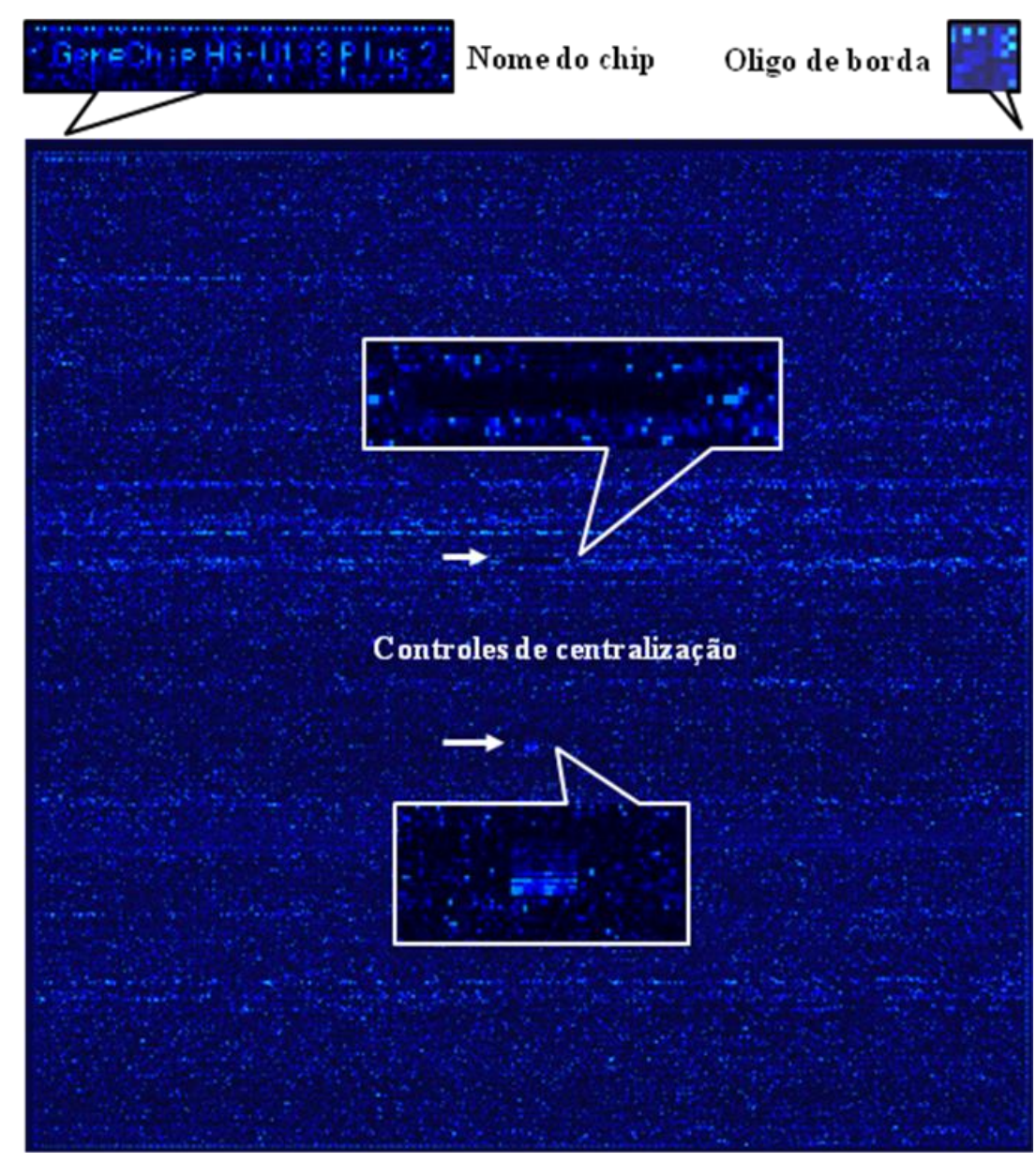

Figura 24. Amplificação da imagem do array. Amplificando as imagens geradas pelo escâner verifica-se a presença dos controles de centralização, nome do chip e oligos de borda. Estes parâmetros de referência necessários para alinhamento e leitura do programa de captura do sinal de cada transcrito. 


\subsubsection{Controles de Marcação}

Genes de Bacillus subitilis (lys, phe, thr e dap) acrescidos de caudas poli-A, participam como controle na etapa de amplificação e marcação com biotina, monitorando a integridade das amostras. Todos os genes devem ser detectados e a taxa de expressão dos spike devem obedecer à crescente lys, phe, thr e dap. (Figura 28)

\subsubsection{Controles de hibridização}

Os controles de hibridização bioB, $\boldsymbol{b i o} \boldsymbol{C}$, bioD são genes envolvidos na síntese de biotina de E.coli e o cre é o gene recombinase do bacteriófago P1. O bioB deve estar presente em pelo menos $50 \%$ dos casos devido sua alta sensibilidade de reação e os demais devem apresentar médias crescentes de concentração no sinal na ordem bioB, bioC, bioD e cre. (Figura 29)

\subsubsection{Controles Internos (Housekeeping Genes)}

Para determinar a ocorrência de degradação das amostras ou ineficiência na transcrição, a razão do sinal das sondas HSAC07 (Beta actina) e GAPDH (Gliceraldeido-3-fosfato dehidrogenase) é calculada esperando não ultrapassar o limite de 5, entretanto para os protocolos em dois ciclo de amplificação é comum que os valores fiquem sempre acima de 5. Particularmente o gene de Beta actina não é a melhor referência para uma célula que possui uma alta modificação do citoesqueleto. Dessa forma os não devemos considerar os gene housekeeping isoladamente, mas no contexto com as outras métricas de qualidade do ensaio (Figura 30) 


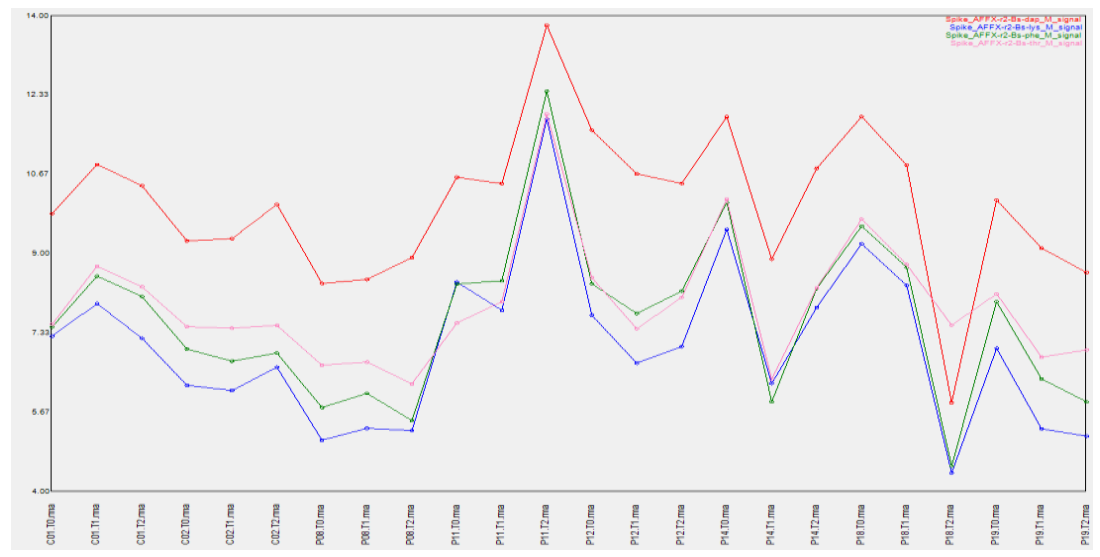

Figura 25. O gráfico de controle de marcação. $\mathrm{O}$ gráfico mostra que a maioria dos arrays (eixo x) manteve a ordem crescentes dos genes lys (azul), phe (verde), thr (rosa) e dap (vermelho), ocorendo uma inversão entre nos valores de phe (verde) e thr (rosa) nas amostras P11.T0, P11.T1 e P12.T1 indicando possível degradação das amostras.

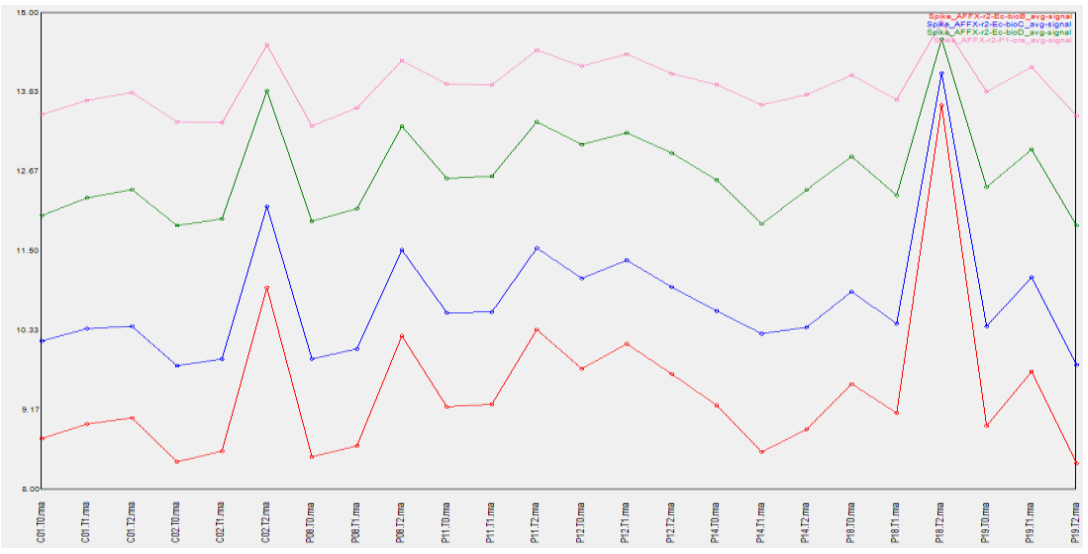

Figura 26. $\mathrm{O}$ gráfico de controle de hibridização $\mathrm{O}$ gráfico mostra no eixo $\mathrm{x}$ os arrays e no eixo y os valores dos controles em ordem crescente bioB (vermelho), bioC (azul), bioD (verde) $\boldsymbol{e}$ cre (rosa) indicando que a hibridação foi bem sucedida.

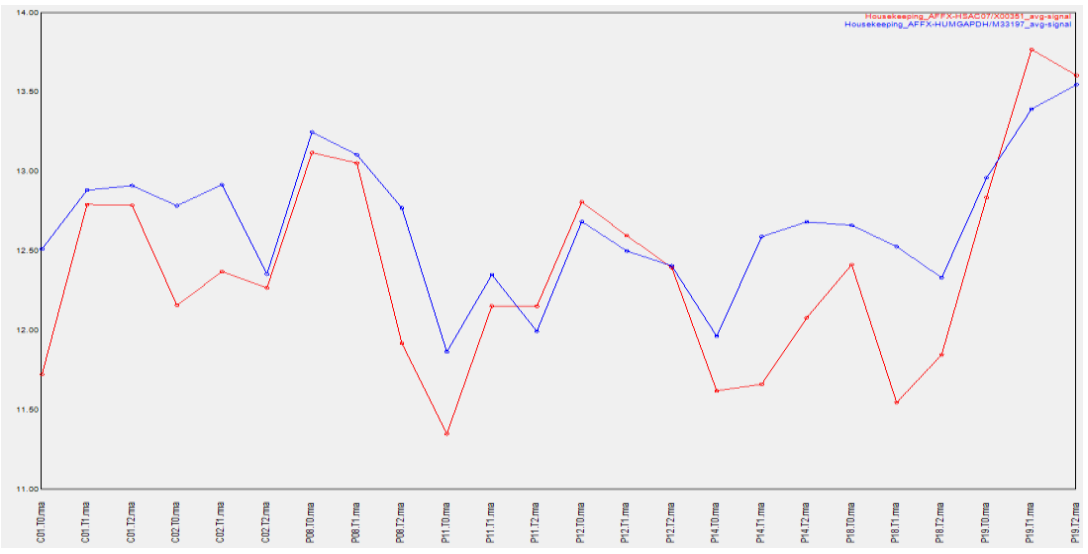

Figura 27. O gráfico de controle de controle interno. O gráfico mostra que os valores foram superiores a 5 tanto para HSAC07 (azul) como para GAPDH (vermelho), indicando uma provável degradação da amostra durante sua manipulação ou no processo de extração do RNA. 


\subsubsection{Métricas de Análise de Expressão:}

\subsubsection{Histograma da intensidade de sinais das sondas}

O histograma abaixo demonstra a distribuição da intensidade do sinal das sondas de todos os arrays. Idealmente espera-se que as curvas mantenham similaridade entre si com pequenos des locamentos relacionados a variações biológicas pertinentes as amostras. As distribuições dos picos dos sinais apresentaram similaridade com uma boa distribuição entre os arrays indicando que os processos foram estáveis, exceto pelo acentuado desvio na curva do array P18 T2. .

\subsubsection{Intensidade de sinais das sondas}

O gráfico em escala logarítmica apresenta os valores de intensidade das sondas detectados nos arrays. O gráfico permite visualizar diferenças de intensidade entre os arrays, causadas pela variação da expressão dos transcritos e por possíveis erros sistemáticos a longo do ensaio. Em geral, poucas diferenças na distribuição são esperadas em razão dos valores não estarem normalizados.

\subsubsection{Normalização e Suma rização}

Os valores de intensidade dos sinais foram tratados pelo algoritmo RMA (Robust Multichip Analysis) para correção do sinal de fundo (background), normalização quantílica e sumarização, no intuito de minimizar a variância sem comprometer a diferença absoluta na expressão dos genes. O gráfico em escala logarítmica apresenta a distribuição dos valores de expressão dos sinais ou índices de expressão. 


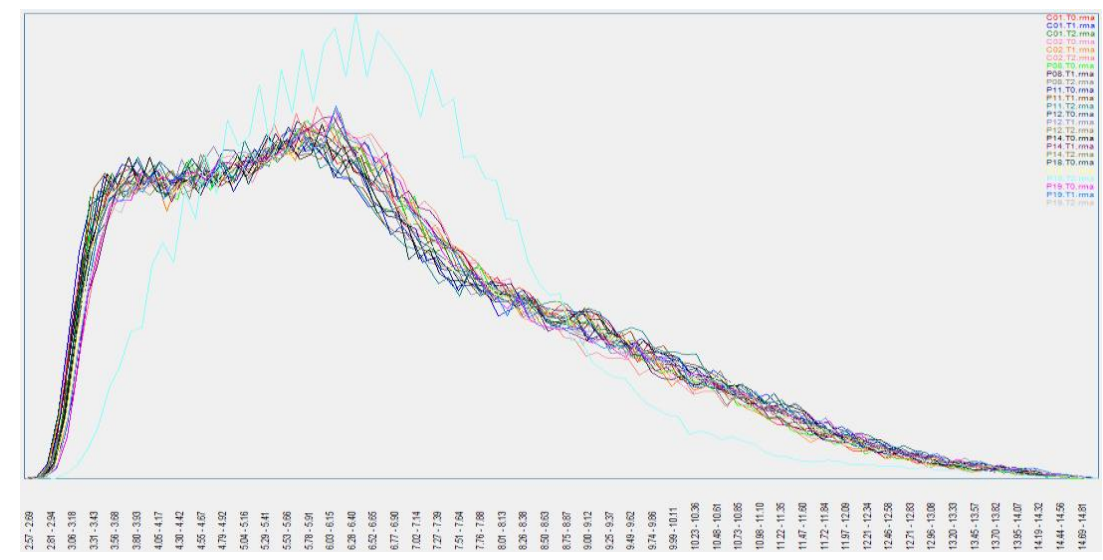

Figura 28. Histograma de distribuição de sinal. O histograma apresentou uma distribuição similar de sinais entre a maioria dos arrays, indicando estabilidade, apesar do desvio no array $\mathrm{P} 18 \mathrm{~T} 2$ em relação aos outros arrays.

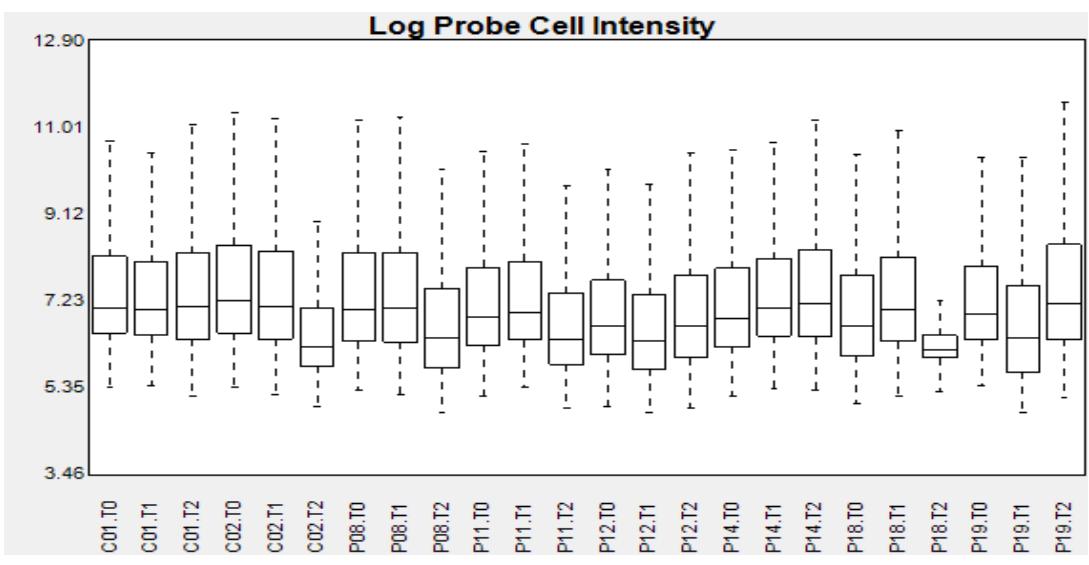

Figura 29. Gráfico de intensidade de sinais. Gráfico mostra as diferenças das intensidades encontradas em cada array. Nota-se que o array P18 T2 apresentou menor intensidade e maior diferença em relação ao outros arrays.

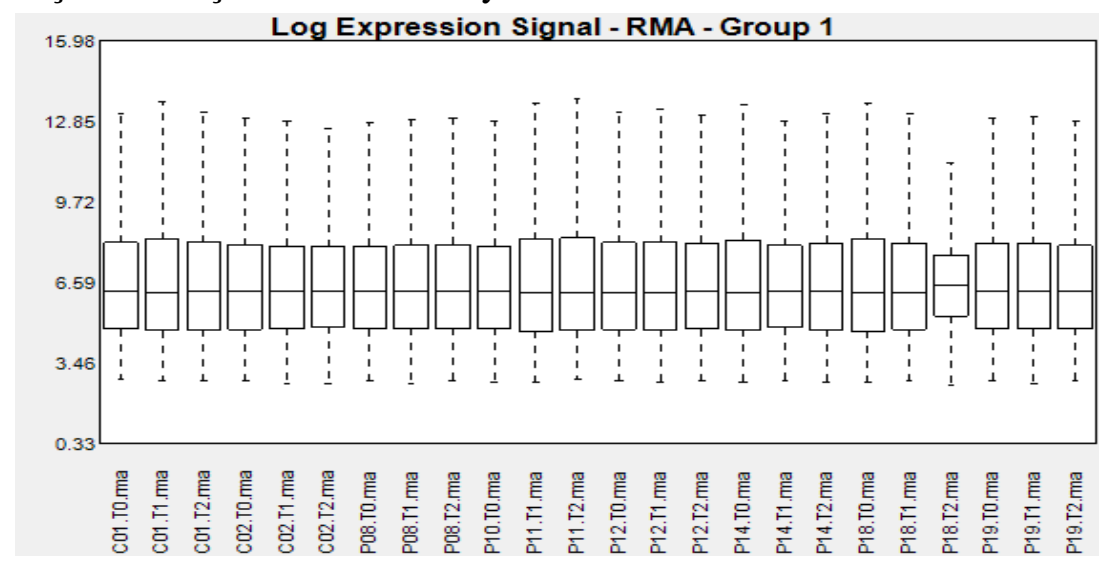

Figura 30. Gráfico de Sinal de Expressão. Os valores do sinal de expressão foram escalonados para diminuir a diferenças entre os arrays e relacionar os transcritos expressos com intensidade semelhante. 


\subsubsection{Genes diferencialmente expressos - DEGs}

Após a normalização e sumarização, os valores de expressão foram submetidos à análise estatística para a determinação de significância, eliminação dos falsos positivos pela determinação da taxa de descobertas falsas (FDR - false discovery rate) e estabelecimento dos genes diferencialmente expressos (DEG). Para maximizar a confiabilidade dos resultados optamos pela aplicação em conjunto dos programas LIMMA (Linear Models for Microarray Analysis) e RankProd (Rank Product Non-Parametric Method).

Optamos por esta estratégia de análise no intuito de selecionar genes com maior probabilidade de modulação ou expressão diferencial entre os controles e os pacientes nos três momentos da cultura (T0, T1 e T2). O algoritmo LIMMA (teste-t moderado) selecionou, dentre o número médio $\equiv 16.900$ de genes inicialmente detectados nos arrays 1.414 em T0, 1.957 em T1 e 2.138 em T2. Já o teste RankProd selecionou 61 em T0, 276 em T1 e 116 em T2. Ao combinarmos os dois métodos encontramos genes comuns entre eles, sendo 28 em T0, 143 em T1 e 57 em T2 (Tabela x). Em razão da baixa qualidade do array P18.T2, optamos por excluí-lo para não afetar os resultados das análises.

Tabela 3. Genes diferencialmente expressos (DEG).

\begin{tabular}{|l|c|c|c|c|}
\hline \multicolumn{1}{|c|}{ Estado } & Análise & $\begin{array}{c}\text { Limma } \\
(\mathbf{p}<\mathbf{0 . 0 5})\end{array}$ & $\begin{array}{c}\mathbf{R P} \\
(\mathbf{p}<\mathbf{0 . 0 5})\end{array}$ & $\begin{array}{c}\text { Limma } \\
\text { vs } \mathbf{R P}\end{array}$ \\
\hline T0 - Imaturo & $\mathbf{2}$ arrays contr. $\mathbf{x} 6$ arrays pac. & 1.414 & 61 & $\mathbf{2 8}$ \\
\hline T1 - Transitório & $\mathbf{2}$ arrays contr. $\mathbf{6}$ arrays pac.s & 1.957 & 276 & $\mathbf{1 4 3}$ \\
\hline T2 - Maduro & $\mathbf{2}$ arrays contr. $\mathbf{5}$ arrays pac. & 2.138 & 116 & $\mathbf{5 7}$ \\
\hline
\end{tabular}


Os números de DEGs encontrados indicam a quantidade de genes comumente expressos no grupo controle (C1 e C2) e grupo de infectados (P8, P11, P12, P14, P18, P19) nas mesmas condições (T0, T1 e T2) com valores de razão de mudança expressão (fold change - FC) diferentes. Os valores de razão de mudança expressão (FC) ou taxa de log, é a diferença por gene entre as médias de dois grupos em escala logarítmica na base 2. Por exemplo, se a média dos níveis de expressão do grupo de infectados for subtraída do grupo controle, os genes com FC de -1 e 3 serão respectivamente regulados 2 vezes para baixo (2-fold) e 8 vezes para cima ( 8 -fold) para os infectados. 


\subsubsection{Genes reprimidos e super-regulados}

\subsubsection{Genes reprimidos e super-regulados em $\mathrm{TO}$}

Dentre os 28 DEG representativos do momento T0, 3 genes foram reprimidos (down regulated) e 21 foram super-regulados (up-regulated). (Figura 34)

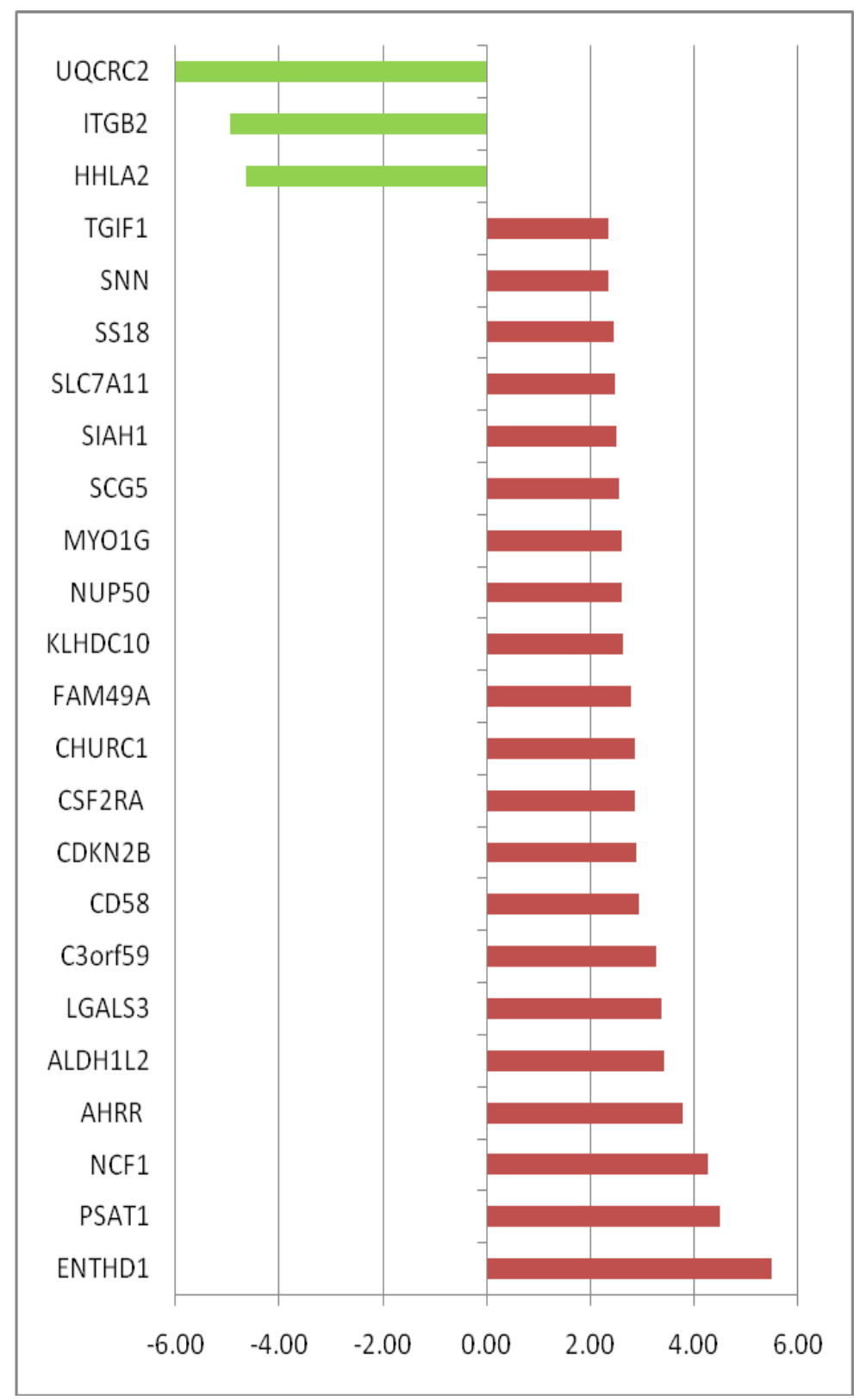

Figura 31. Gráfico de razão de mudança expressão (FC) em T0. O FC dos 3 genes reprimidos (down regulated) em verde variou de -4.64 a -6.32 e o FC dos 21 genes super-regulados (up-regulated) em vermelho variou de 2.77 a 5.49. 


\subsubsection{Genes reprimidos em $\mathrm{T} 1$}

Dentre os 143 DEG representativos do momento T1, 46 genes foram reprimidos (down regulated) (Figura 35)

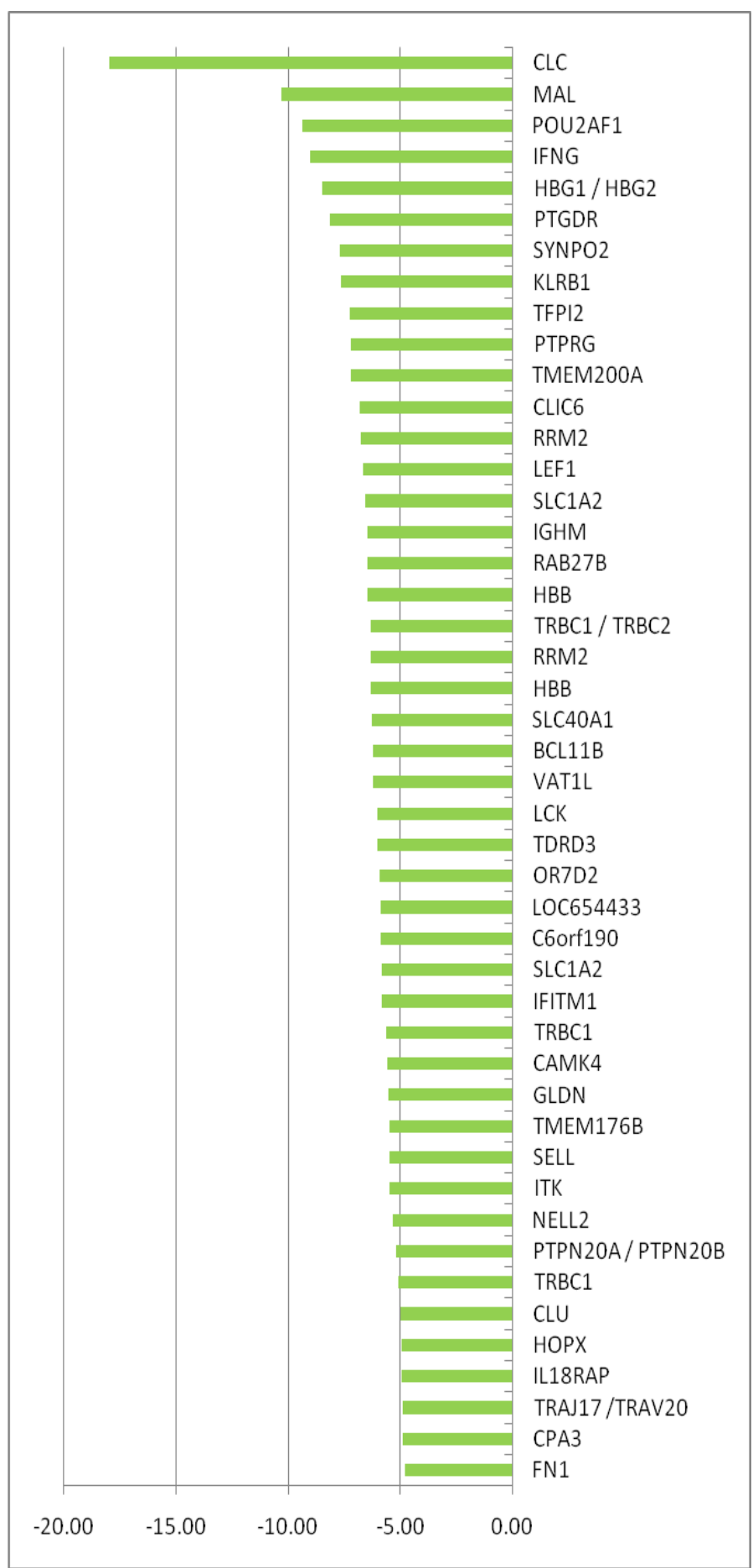

Figura 32. Gráfico de razão de mudança expressão (FC) em T1. O FC dos 45 genes reprimidos (down regulated) em verde variou de -18.00 a -6.32 . 


\subsubsection{Genes super-regulados em $\mathrm{T} 1$}

Dentre os 143 DEG representativos do momento T1, 78 genes superregulados (up-regulated) (Figura 36)

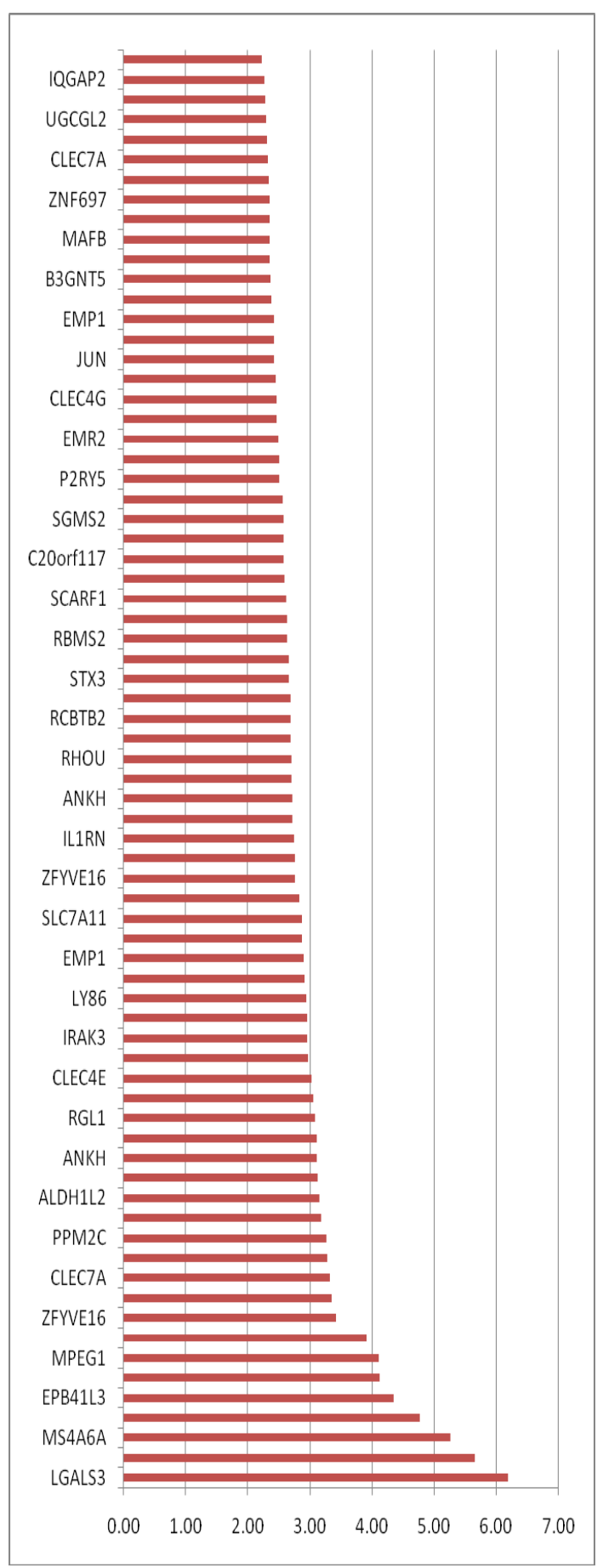

Figura 33. Gráfico de razão de mudança expressão (FC) em T1. FC dos 78 genes super-regulados (up-regulated) em vermelho variou de 2.22 a 6.19. 


\subsubsection{Genes super-regulados e reprimidos em $\mathrm{T} 2$}

Dentre os 57 DEG representativos do momento T2, 23 genes foram reprimidos (down regulated) e 27 foram super-regulados (up-regulated).

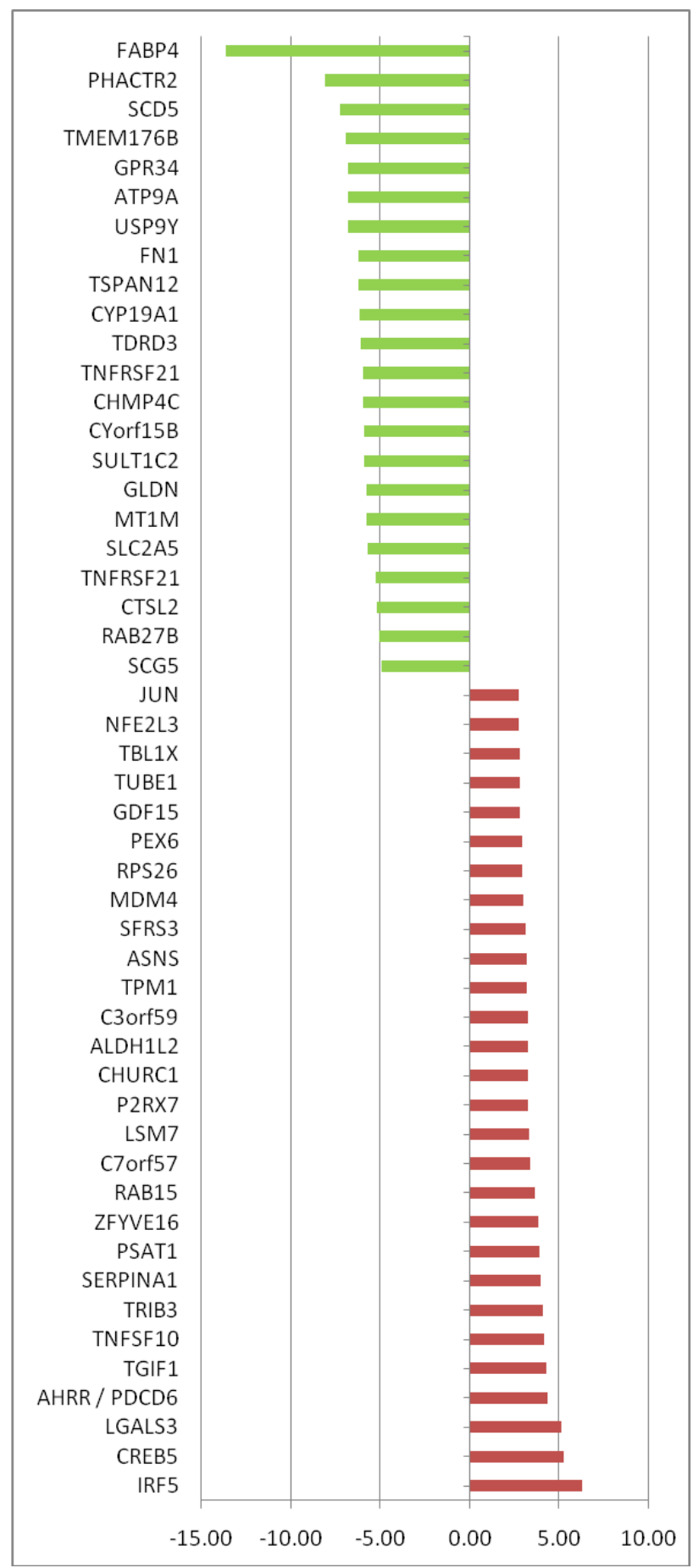

Figura 34. Gráfico de razão de mudança expressão (FC) em T2. O FC dos 23 genes reprimidos (verde) variou de -13.64 a -4.79 e o FC dos 27 genes superregulados (up-regulated) em vermelho variou de 2.74 a 6.30 . 


\subsubsection{Análise de vias funcionais}

Gerar listas de genes regulados não é suficiente para compreender as funções dos genes regulados e seu papel nos processos biológicos e fisiológicos. Utilizamos o programa Ingenuity Pathways Analysis (Ingenuity ${ }^{\circledR}$ Systems, www.ingenuity.com), para a obtenção da descrição dos genes, seu significado biológico e sua participação em vias e redes funcionais.

Para obtenção das informações baseada no potencial dos genes regulados e para identificar os eventos e mecanismos moleculares que caracterizam cada momento da cultura de células dendríticas utilizadas no modelo de vacina terapêutica anti-HIV-1, o programa utiliza sua base de conhecimento (Ingenuity Pathways Knowledge Base). Esta base representa um dos maiores banco de dados da atualidade, de redes biológicas criadas a partir de milhões de relações, modeladas individualmente, de proteínas, genes, complexos, células, tecidos, drogas e doenças.

Todos os identificadores da função "core analysis" foram utilizados e as redes foram ordenadas de acordo com escore de significância. A significância da biofunção e das vias canônicas foram testadas pelo valor de $\mathrm{p}$ do teste Exato de Fisher. As biofunções foram agrupadas em: Doenças e Disfunções; Funções Moleculares e Celulares, e Função e desenvolvimento do sistema fisiológico. De um modo semelhante vias canônicas foram agrupadas em Vias Metabólicas e vias de sinalização. Vias canônicas também foram ordenadas pelo valor de relação (número de moléculas em uma via, uma vez que satisfazendo os critérios de corte, dividido pelo número total de moléculas que compõem essa via). 


\subsubsection{Seleção dos 10 DEG em T0}

O programa IPA selecionou os 10 genes que apresentaram o maior e o menor FC nos momentos T0, T1 e T2. O descritivo dos genes esta nos anexos $\mathrm{A}, \mathrm{B}$ e C

Tabela 4. Os 10 genes mais superregulados e reprimidos em T0.

\section{Fold Change up-regulated}

\begin{tabular}{lll} 
Molecules & Exp. Value & \\
\hline ENTHD1 & $\uparrow 5.492 \longrightarrow$ ENTH domain containing 1 \\
PSAT1 & $\uparrow 4.495 \longrightarrow$ Posphoserine aminotransferase 1 \\
SNN & $\uparrow 3.428 \longrightarrow$ Stannin \\
LGALS3 & $\uparrow 3.368 \longrightarrow$ Lectin, galactoside-binding, soluble, 3 \\
KLHDC10 & $\uparrow 3.281 \longrightarrow$ kelch domain containing 10 \\
ALDH1L2 & $\uparrow 2.946 \longrightarrow$ Full length insert cDNA clone ZA02A01 \\
PDCD6 & $\uparrow 2.882 \longrightarrow$ Unknown \\
CSF2RA (includes EG:1438) & $\uparrow 2.873 \longrightarrow$ Colony stimulating factor 2 recp., alpha, (granulocyte-macrophage) \\
MYO1G & $\uparrow 2.859 \longrightarrow$ Myosin IG \\
CD58 & $\uparrow 2.777 \longrightarrow$ Lymphocyte function-associated antigen 3
\end{tabular}

\section{Fold Change down-regulated}

\begin{tabular}{lcl} 
Molecules & Exp. Value & \\
\hline SCG5 & $\downarrow-6.322 \longrightarrow$ & HERV-HLTR-associating 2 \\
ITGB2 & $\downarrow-4.958 \longrightarrow$ & Integrin, beta 2 (complement component 3 recp. 3 and 4 subunit) \\
HHLA2 & $\downarrow-4.642 \longrightarrow$ & Secretogranin V (7B2 protein) \\
\hline
\end{tabular}


Tabela 5. Os 10 genes mais superregulados e reprimidos em T1.

\section{Fold Change up-regulated}

\begin{tabular}{lcl} 
Molecules & Exp. Value & \\
\hline LGALS3 & $\uparrow 6.191 \longrightarrow$ Lectin, galactoside-binding, soluble, 3 \\
CLEC7A* & $\uparrow 5.664 \longrightarrow$ C-type lectin domain family 7, member A \\
ZFWE16* & $\uparrow 4.773 \longrightarrow$ Zinc finger, FYVE domain containing 16 \\
EPB41L3* & $\uparrow 4.345 \longrightarrow$ Erythrocyte membrane protein band 4.1-like 3 \\
GPNMB & $\uparrow 4.127 \longrightarrow$ Glycoprotein (transmembrane) nmb \\
MPEG1* & $\uparrow 4.106 \longrightarrow$ Macrophage expressed 1 \\
KCNJ15 & $\uparrow 3.276 \longrightarrow$ Potassium inwardly-rectifying channel, subfamily J, member 15 \\
PPM2C & $\uparrow 3.262 \longrightarrow$ Protein phosphatase 2C, magnesium-dependent, catalytic subunit \\
PTPRE & $\uparrow 3.176 \longrightarrow$ Protein tyrosine phosphatase, receptor type, E \\
ALDH1L2 & $\uparrow 3.160 \longrightarrow$ Full length insert cDNA clone ZA02A01
\end{tabular}

\section{Fold Change down-regulated}

\begin{tabular}{|c|c|c|}
\hline Molecules & Exp. Value & \\
\hline CLC & $\downarrow-17.978$ & Charcot-Leyden crystal protein \\
\hline MAL & $\downarrow-10.314 \longrightarrow$ & mal, T-cell differentiation protein \\
\hline POU2AF1 & $\downarrow-9.346$ & POU class 2 associating factor 1 \\
\hline IFNG & $\downarrow-9.012$ & Interferon, gamma \\
\hline HBG2 & $\downarrow-8.500$ & Hemoglobin, gamma A/ll hemoglobin, gamma G \\
\hline PTGDR & $\downarrow-8.151$ & Prostaglandin D2 receptor (DP) \\
\hline SYNPO2 & $\downarrow-7.671$ & Synaptopodin 2 \\
\hline KLRB1 & $\downarrow-7.663 \longrightarrow$ & Killer cell lectin-like receptor subfamily B, member 1 \\
\hline TFPI2 & $\downarrow-7.243 \longrightarrow$ & Tissue factor pathway inhibitor 2 \\
\hline PTPRG & $\downarrow-7.217 \longrightarrow$ & Protein tyrosine phosphatase, receptor type, $G$ \\
\hline
\end{tabular}


Tabela 6. Os 10 genes mais superregulados e reprimidos em T2.

\section{Fold Change up-regulated}

\begin{tabular}{lcl} 
Molecules & Exp. Value & \\
\hline IRF5 & $\uparrow 6.305 \longrightarrow$ & Interferon regulatory factor 5 \\
CREB5 & $\uparrow 5.264 \longrightarrow$ cAMP responsive element binding protein 5 \\
LGALS3 & $\uparrow 5.173 \longrightarrow$ Lectin, galactoside-binding, soluble, 3 \\
PDCD6 & $\uparrow 4.381 \longrightarrow$ Unknown \\
TGIF1 & $\uparrow 4.292 \longrightarrow$ TGFB-induced factor homeobox 1 (TGIF1), transcript variant 1, mRNA \\
TNFSF10 & $\uparrow 4.187 \longrightarrow$ Tumor necrosis factor (ligand) superfamily, member 10 \\
TRIB3 & $\uparrow 4.135 \longrightarrow$ Tribbles homolog 3 (Drosophila) \\
SERPINA1 & $\uparrow 3.998 \longrightarrow$ Serpin peptidase inhibitor, clade A (alpha-1 antiproteinase, antitrypsin) \\
PSAT1 & $\uparrow 3.927 \longrightarrow$ Phosphoserine aminotransferase 1 \\
ZFWE16 & $\uparrow 3.830 \longrightarrow$ Zinc finger, FYVE domain containing 16
\end{tabular}

Fold Change down-regulated

\begin{tabular}{|c|c|c|c|}
\hline Molecules & Exp. Value & & \\
\hline FABP4 & $\downarrow-13.641$ & $\rightarrow$ & Fatty acid binding protein 4 , adipocyte \\
\hline PHACTR2 & $\downarrow-8.094$ & 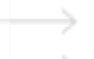 & Phosphatase and actin regulator 2 \\
\hline SCD5 & $\downarrow-7.236$ & 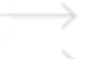 & Stearoyl-CoA desaturase 5 \\
\hline TMEM176B & $\downarrow-6.948$ & 3 & Transmembrane protein 176B \\
\hline GPR34 & $\downarrow-6.826$ & & G protein-coupled receptor 34 \\
\hline ATP9A & $\downarrow-6.796$ & $\vec{\longrightarrow}$ & ATPase, class Il, type 9A \\
\hline USP9Y & $\downarrow-6.766$ & $\vec{\longrightarrow}$ & Unknown \\
\hline FN1 & $\downarrow-6.217$ & $\Rightarrow$ & Fibronectin 1 \\
\hline TSPAN12 & $\downarrow-6.199$ & $\vec{b}$ & Tetraspanin 12 \\
\hline CYP19A1 & $\downarrow-6.174$ & 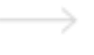 & Cytochrome P450, family 19 , subfamily A, polypeptide 1 \\
\hline
\end{tabular}




\subsubsection{Biofunções}

O programa IPA relaciona as biofunções aos genes diferencialmente expressos. Cada biofunção é ordenada segundo o valor de p e agrupada em temas relacionados as funções moleculares e celulares, função e desenvolvimento do sistema fisiológico e doenças/disfunções.

Reunimos em uma única lista as informações de T0, T1 e T2 relacionadas aos mesmos temas para compararmos os achados.

Tabela 7. Funções celulares e moleculares dos genes diferencialmente expressos em T0, T1 e T2.

\begin{tabular}{|c|c|c|c|c|c|c|c|c|}
\hline \multicolumn{3}{|c|}{ T0 - DCs imaturas } & \multicolumn{3}{|c|}{ T1 - DCs transitórias } & \multicolumn{3}{|c|}{ T2 - DCs Maturadas } \\
\hline Nome & Valor de $p$ & $\begin{array}{c}\text { N. } \\
\text { Gene }\end{array}$ & Nome & Valor de $p$ & $\begin{array}{c}\text { N. } \\
\text { Gene }\end{array}$ & Nome & Valor de $p$ & $\begin{array}{c}\text { N. } \\
\text { Gene }\end{array}$ \\
\hline $\begin{array}{l}\text { Interação e Sinalização } \\
\text { célula a célula }\end{array}$ & $\begin{array}{l}3.20 \mathrm{E}-04- \\
3.85 \mathrm{E}-02\end{array}$ & 7 & Desenvolvimento Celular & $\begin{array}{l}1.33 \mathrm{E}-06- \\
5.23 \mathrm{E}-03\end{array}$ & 24 & Morte Celular & $\begin{array}{l}1.04 \mathrm{E}-06- \\
1.29 \mathrm{E}-02\end{array}$ & 17 \\
\hline Organização Celular & $\begin{array}{c}3.20 \mathrm{E}-04- \\
2.75 \mathrm{E}-02\end{array}$ & 5 & Apresentação antigenica & $\begin{array}{c}1.25 \mathrm{E}-05- \\
5.23 \mathrm{E}-03\end{array}$ & 19 & Movimento Celular & $\begin{array}{c}1.57 \mathrm{E}-04- \\
1.29 \mathrm{E}-02\end{array}$ & 11 \\
\hline Morfologia Celular & $\begin{array}{l}3.23 \mathrm{E}-05- \\
4.95 \mathrm{E}-02\end{array}$ & 3 & $\begin{array}{l}\text { Interação e Sina lização célula } \\
\text { a célula }\end{array}$ & $\begin{array}{l}1.40 \mathrm{E}-06- \\
5.23 \mathrm{E}-03\end{array}$ & 24 & Organização Celular & $\begin{array}{l}1.82 \mathrm{E}-04- \\
1.29 \mathrm{E}-02\end{array}$ & 10 \\
\hline Morte Celular & $\begin{array}{c}6.14 \mathrm{E}-04- \\
4.96 \mathrm{E}-02\end{array}$ & 8 & Morte Celular & $\begin{array}{c}2.49 \mathrm{E}-06- \\
5.23 \mathrm{E}-03\end{array}$ & 36 & Ciclo Celular & $\begin{array}{c}3.76 \mathrm{E}-04- \\
1.29 \mathrm{E}-02\end{array}$ & 10 \\
\hline Movimento Celular & $\begin{array}{l}\text { 8.43E-05 - } \\
4.47 \mathrm{E}-02\end{array}$ & 3 & Sinalização Celular & $\begin{array}{c}5.81 \mathrm{E}-06- \\
5.10 \mathrm{E}-03\end{array}$ & 20 & $\begin{array}{l}\text { Crescimento e } \\
\text { proliferação celular }\end{array}$ & $\begin{array}{c}4.28 \mathrm{E}-05- \\
1.29 \mathrm{E}-02\end{array}$ & 15 \\
\hline
\end{tabular}


Tabela 8. Funções e desenvolvimento fisiológico relacionados ao genes diferencialmente expressos em T0, T1 e T2.

\begin{tabular}{|c|c|c|c|c|c|c|c|c|}
\hline \multicolumn{3}{|c|}{ T0 - DCs imaturas } & \multicolumn{3}{|c|}{ T1 - DCs transitórias } & \multicolumn{3}{|c|}{ T2 - DCs Maturadas } \\
\hline Tráfico de células imune & $\begin{array}{c}3.23 \mathrm{E}-05- \\
4.95 \mathrm{E}-02\end{array}$ & 4 & $\begin{array}{l}\text { Função e desenvolvimento do } \\
\text { sistema hematológico }\end{array}$ & $\begin{array}{l}1.33 \mathrm{E}-06- \\
5.23 \mathrm{E}-03\end{array}$ & 24 & Tráfico de células imune & $\begin{array}{l}1.60 \mathrm{E}-04- \\
1.03 \mathrm{E}-02\end{array}$ & 7 \\
\hline Hematopoiese & $\begin{array}{r}3.23 \mathrm{E}-05- \\
4.44 \mathrm{E}-02\end{array}$ & 4 & Tráfico de células imune & $\begin{array}{c}3.61 \mathrm{E}-06- \\
5.23 \mathrm{E}-03\end{array}$ & 15 & $\begin{array}{l}\text { Função e desenvolvimento do } \\
\text { sistema hematológico }\end{array}$ & $\begin{array}{l}1.60 \mathrm{E}-04- \\
1.09 \mathrm{E}-02\end{array}$ & 12 \\
\hline $\begin{array}{l}\text { Função e desenvolvimento do } \\
\text { sistema hematológico }\end{array}$ & $\begin{array}{c}3.23 \mathrm{E}-05- \\
4.95 \mathrm{E}-02\end{array}$ & 5 & $\begin{array}{l}\text { Desenvolvimento e estrutura } \\
\text { de tecidos linfóides }\end{array}$ & $\begin{array}{l}\text { 8.22E-06 - } \\
5.23 \mathrm{E}-03\end{array}$ & 13 & Desenvolvimento do organismo & $\begin{array}{l}3.09 \mathrm{E}-05- \\
9.04 \mathrm{E}-03\end{array}$ & 9 \\
\hline
\end{tabular}

Nota: O programa IPA permite visualizar os genes envolvidos nas categorias clicando sobre o nome de cada uma delas, neste formato a tabela limita-se a mostrar somente o número de genes sem descriminá-los. 
Tabela 9 Doenças e desordens relacionados ao genes diferencialmente expressos em T0, T1 e T2.

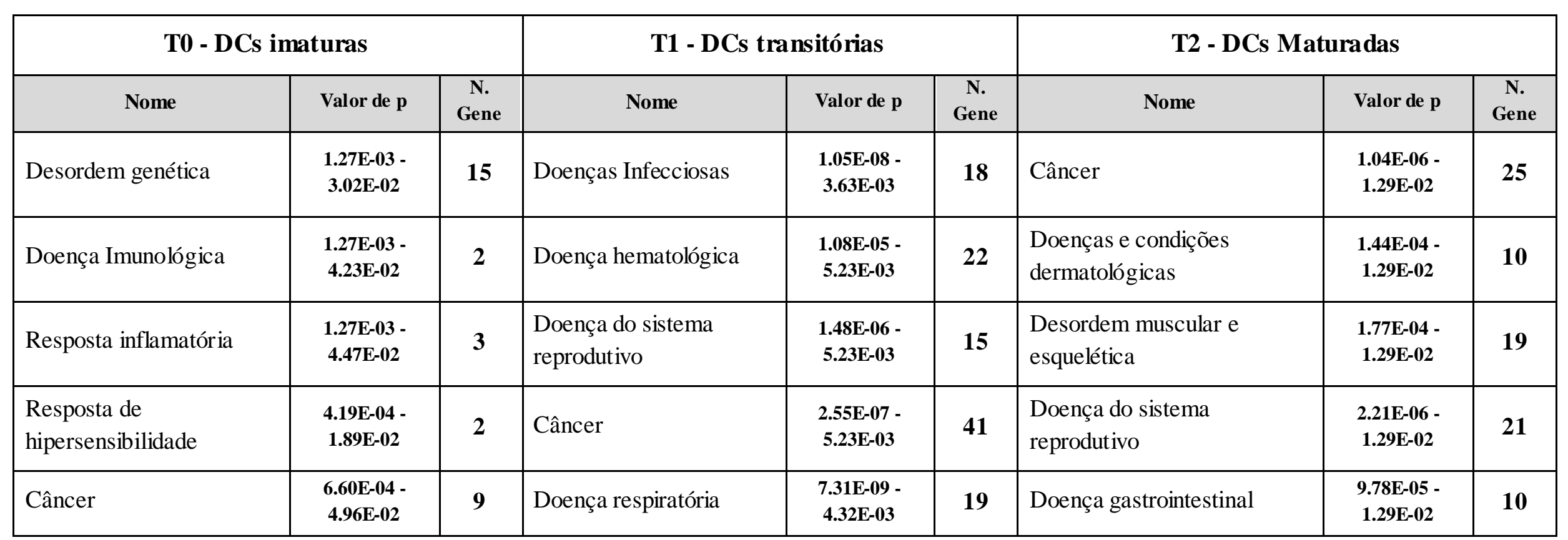

Nota: O programa IPA permite visualizar os genes envolvidos nas categorias clicando sobre o nome de cada uma delas, neste formato a tabela limita-se a mostrar somente o número de genes sem descriminá-los. 


\subsubsection{Representação gráfica das funções biológicas:}

Os histogramas ordenam as funções biológicas (eixo x), independente do tema e de acordo valor de p significante (eixo y) dos genes relacionados. A linha do limiar (vermelho) denota o valor de corte (cutoff) para a significância. Este tipo de representação auxilia na visualização das funções mais evidentes no sistema estudado. Selecionamos as 20 funções mais significantes para os histogramas de T0, T1 e T2.

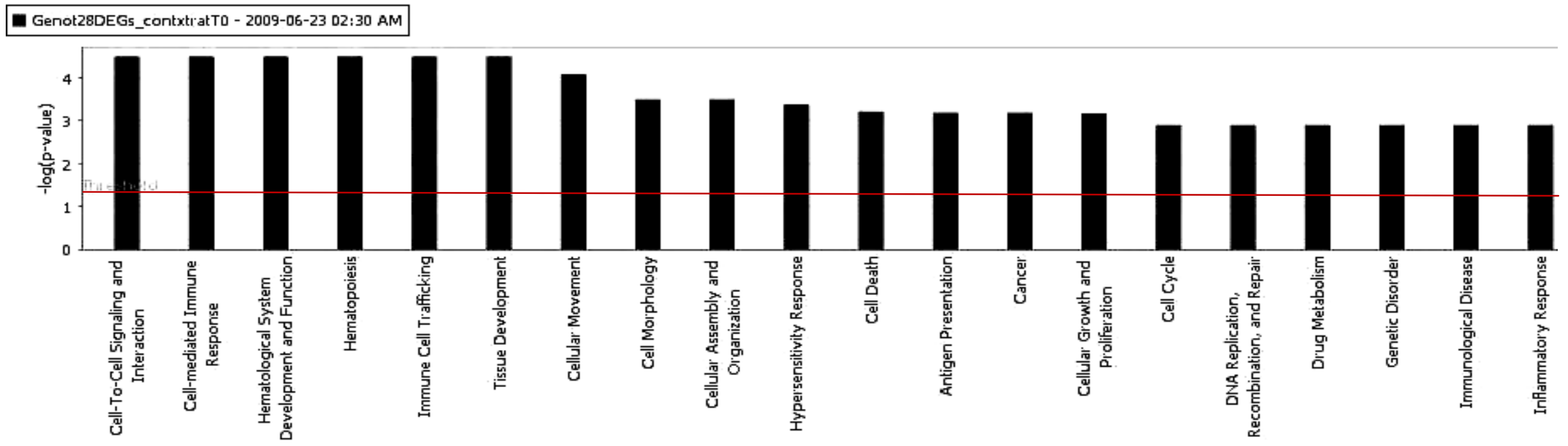

Figura 35. Histograma de funções biológicas de T0. Em T0 os genes relacionados as funções de interação célula a célula, resposta mediada por células, movimento e morfologia celular correspondem com as características mais evidentes das DC no estado imaturo. 
Genot143DEG__contxtratT1 - 2009-06-23 02:36 AM

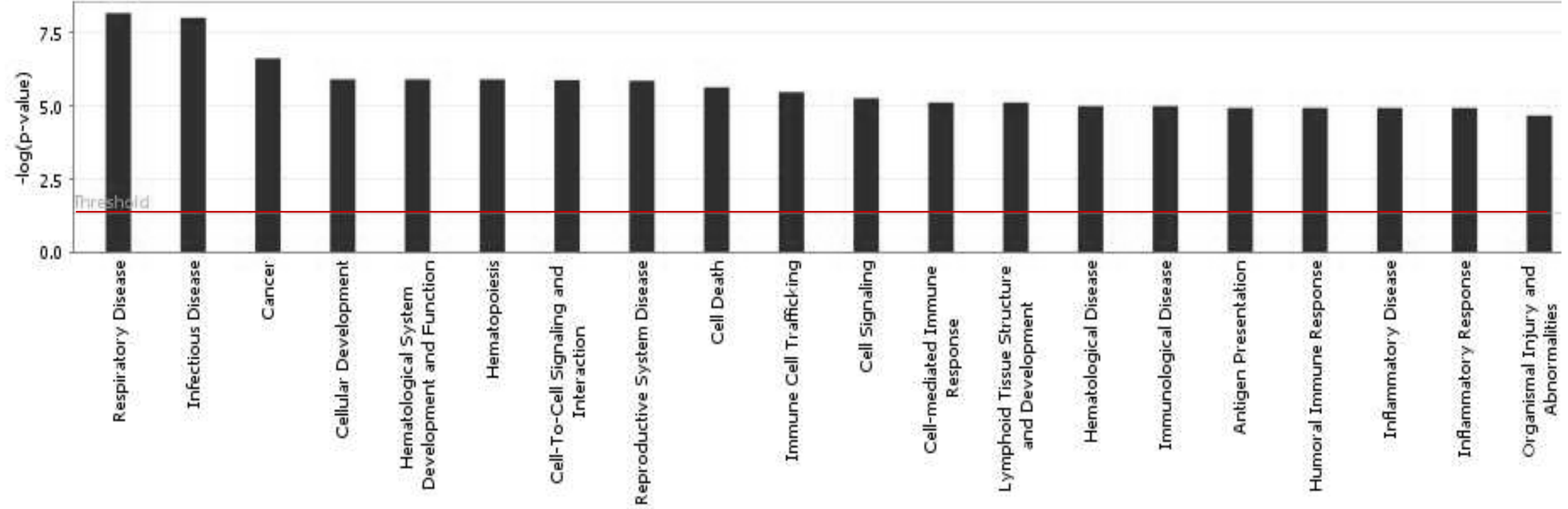

Figura 36. Histograma de funções biológicas de T1. Em T1 a presença dos genes relacionados as funções de doenças infecciosas, interação e sinalização celular, resposta imune mediada por célula, resposta imune humoral,apresentação antigenica, morte celular entre outras, caracterizam o momento correspondente ao contato com o HIV inativado. 


\section{Genot57DEGs_contxtratT2 - 2009-06-23 02:37 AM}

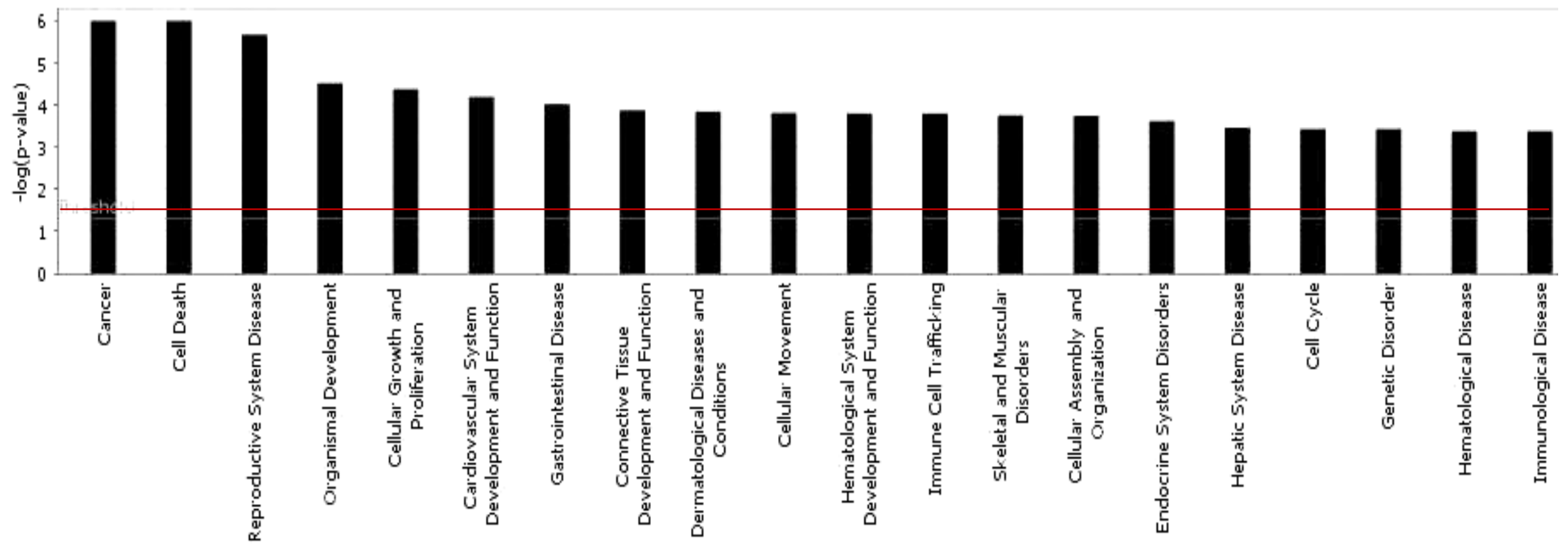

Figura 37. Histograma de funções biológicas de T2. Em T2 o destaca-se a função de morte celular com o maior valor de significância dentre as outras funções, podendo indicar os efeitos do prolongado tempo de cultura somado ao contato com o HIV e ao processo de maturação com citocinas pró-inflamatória. 


\subsubsection{Vias canônicas}

As vias canônicas foram agrupadas em vias metabólicas e vias de sinalização. Vias canônicas foram ordenadas pelo valor da razão, isto é, o número de moléculas em uma via, uma vez que satisfaça os critérios de corte, dividido pelo número total de moléculas que compõem essa via.

Tabela 10. Vias canônicas de T0, T1 e T2.

\begin{tabular}{|c|c|c|c|c|c|c|c|c|}
\hline \multicolumn{3}{|c|}{ T0 - DCs imaturas } & \multicolumn{3}{|c|}{ T1 - DCs transitórias } & \multicolumn{3}{|c|}{ T2 - DCs Maturadas } \\
\hline Nome & $\begin{array}{c}\text { Valor de } \\
\text { p }\end{array}$ & Razão & Nome & $\begin{array}{c}\text { Valor de } \\
\text { p }\end{array}$ & Razão & Nome & $\begin{array}{c}\text { Valor de } \\
\text { p } \\
\end{array}$ & Razão \\
\hline $\begin{array}{l}\text { Ciclo Celular: } \\
\text { regulação Checkpoint G1/S }\end{array}$ & $6.63 \mathrm{E}-02$ & $\begin{array}{c}1 / 59 \\
(0.017)\end{array}$ & $\begin{array}{l}\text { Sinalização de receptor de } \\
\text { célula } \mathrm{T}\end{array}$ & $1.28 \mathrm{E}-04$ & $\begin{array}{c}5 / 110 \\
(0.045)\end{array}$ & Sinalização ATM & $3.11 \mathrm{E}-04$ & $\begin{array}{c}3 / 52 \\
(0.058)\end{array}$ \\
\hline Sinalização GM-CSF & $7.46 \mathrm{E}-02$ & $\begin{array}{c}1 / 67 \\
(0.015)\end{array}$ & $\begin{array}{l}\text { Papel do NFAT na regulação da } \\
\text { reposta imune }\end{array}$ & $1.76 \mathrm{E}-04$ & $\begin{array}{c}6 / 192 \\
(0.031)\end{array}$ & $\begin{array}{l}\text { LPS/IL-1 mediados da } \\
\text { inibição da função RXR }\end{array}$ & $1.18 \mathrm{E}-03$ & $\begin{array}{l}4 / 205 \\
(0.02)\end{array}$ \\
\hline Macropinocitose & $7.81 \mathrm{E}-02$ & $\begin{array}{c}1 / 72 \\
(0.014)\end{array}$ & $\begin{array}{l}\text { Sinalização CD28 em células T } \\
\text { auxiliadoras }\end{array}$ & $1.79 \mathrm{E}-04$ & $\begin{array}{l}5 / 125 \\
(0.04)\end{array}$ & $\begin{array}{l}\text { Sinalização de resposta de } \\
\text { fase aguda }\end{array}$ & $9.09 \mathrm{E}-03$ & $\begin{array}{c}3 / 178 \\
(0.017)\end{array}$ \\
\hline $\begin{array}{l}\text { Agrina Interação com Junção } \\
\text { Neuromuscular }\end{array}$ & $8.28 \mathrm{E}-02$ & $\begin{array}{c}1 / 72 \\
(0.014)\end{array}$ & $\begin{array}{l}\text { Sinalização para Doença do } \\
\text { Enxerto Contra Hospedeiro }\end{array}$ & 8.03E-04 & $\begin{array}{c}3 / 43 \\
(0.07)\end{array}$ & $\begin{array}{l}\text { Sinalização de receptores de } \\
\text { morte }\end{array}$ & $1.02 \mathrm{E}-02$ & $\begin{array}{c}2 / 65 \\
(0.031)\end{array}$ \\
\hline Sinalização TGF- $\beta$ & $9.1 \mathrm{E}-02$ & $\begin{array}{c}1 / 77 \\
(0.013)\end{array}$ & $\begin{array}{l}\text { Sinalização iCOS-iCOSL em } \\
\text { células T auxiliadoras }\end{array}$ & $1.33 \mathrm{E}-03$ & $\begin{array}{l}4 / 115 \\
(0.035)\end{array}$ & Via de sinalização NFkB & $1.16 \mathrm{E}-02$ & $\begin{array}{c}2 / 71 \\
(0.028)\end{array}$ \\
\hline $\begin{array}{l}\text { Sinalização do receptor Aril } \\
\text { Hidrocarbono }\end{array}$ & $1.57 \mathrm{E}-01$ & $\begin{array}{c}1 / 151 \\
(0.007)\end{array}$ & $\begin{array}{l}\text { LPS/IL-1 mediados da inibição } \\
\text { da função RXR }\end{array}$ & $1.34 \mathrm{E}-02$ & $\begin{array}{c}4 / 187 \\
(0.021)\end{array}$ & Signalização TGF- $\beta$ & $1.61 \mathrm{E}-02$ & $\begin{array}{c}2 / 77 \\
(0.026)\end{array}$ \\
\hline
\end{tabular}




\subsubsection{Grupo de mapas das redes funcionais}

Programa gerou mapas de redes associadas as funções biológicas considerando os DEG e relacionamentos possíveis para os três momentos.

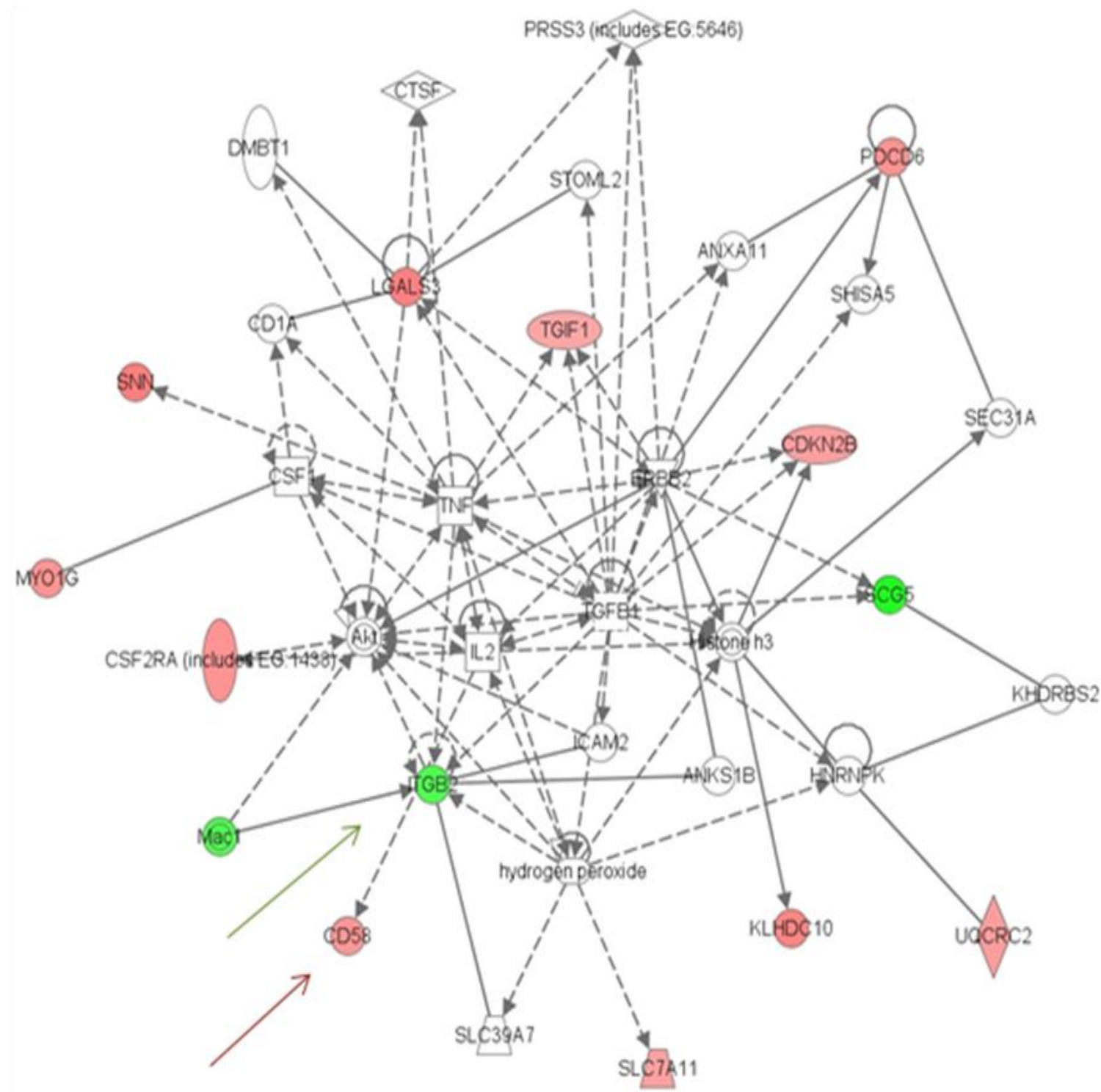

Figura 38. Mapa com via de Sinalização GM-CSF, Macropinocitoses e Signalização TGF- $\beta$ em T0. A figura mostra 14 genes representativos de receptores de membrana ( 0 ), enzimas $(\diamond)$, reguladores de transcrição $(\varnothing)$, transportadores $(\square)$, citocinas $(\square)$ e outros (O) que relacionam-se direta ou (linha fechada) ou indiretamente (linha traçejada) independente de sua regulaçao (super-regulados em vermelho e reprimidos em verde). 


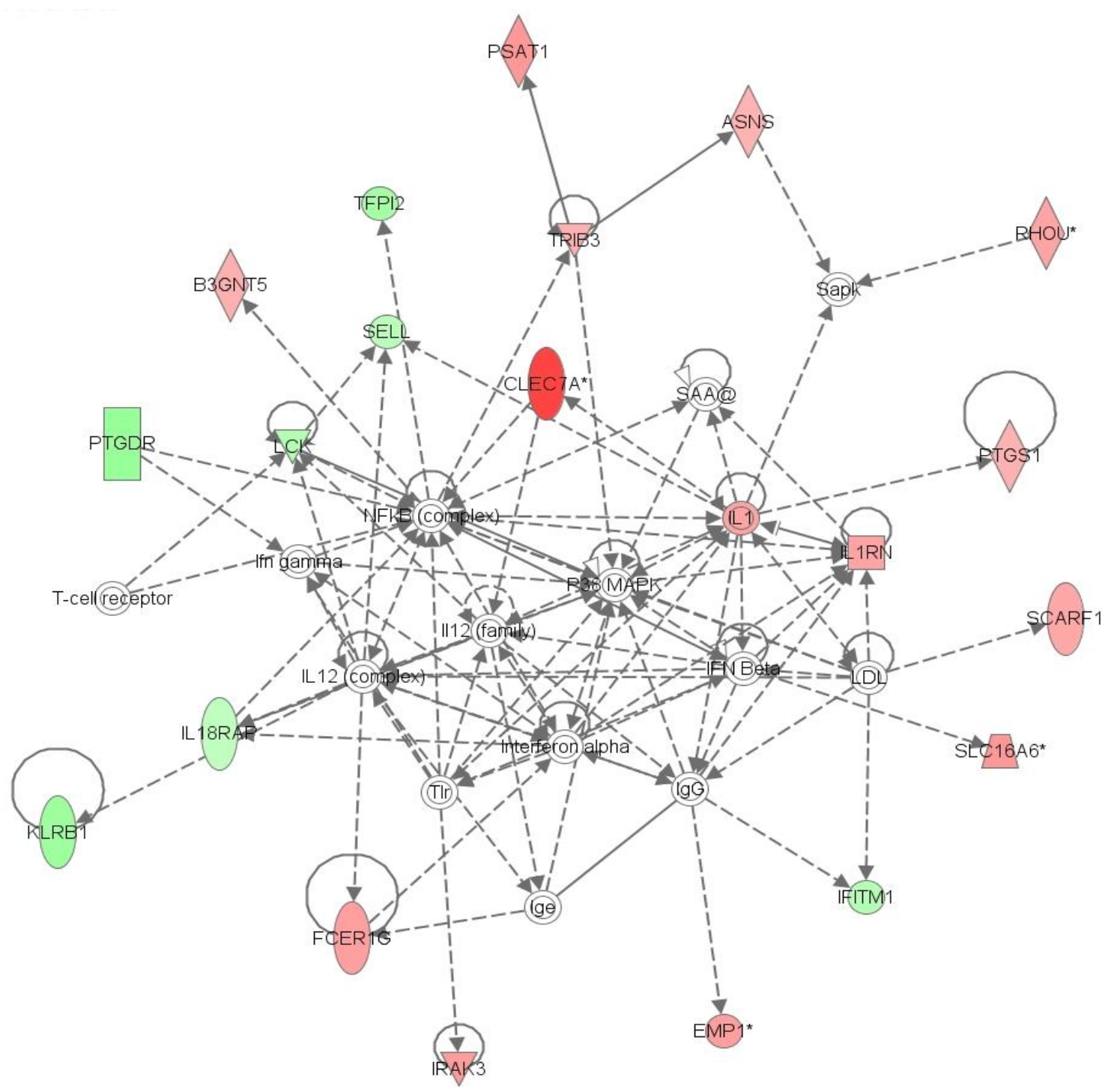

Figura 39. Mapa de via de movimento celular e tráfego de células imunes em T1. A figura mostra 21 genes representativos de receptores de membrana ( 0 , enzimas $(\diamond)$, reguladores de transcrição ( $\circlearrowright$ ), transportadores ( ), citocinas ( $\square$ e outros ( $O$ ) que relacionam-se direta ou (linha fechada) ou indiretamente (linha traçejada) independente de sua regulaçao (super-regulados em vermelho e reprimidos em verde). 


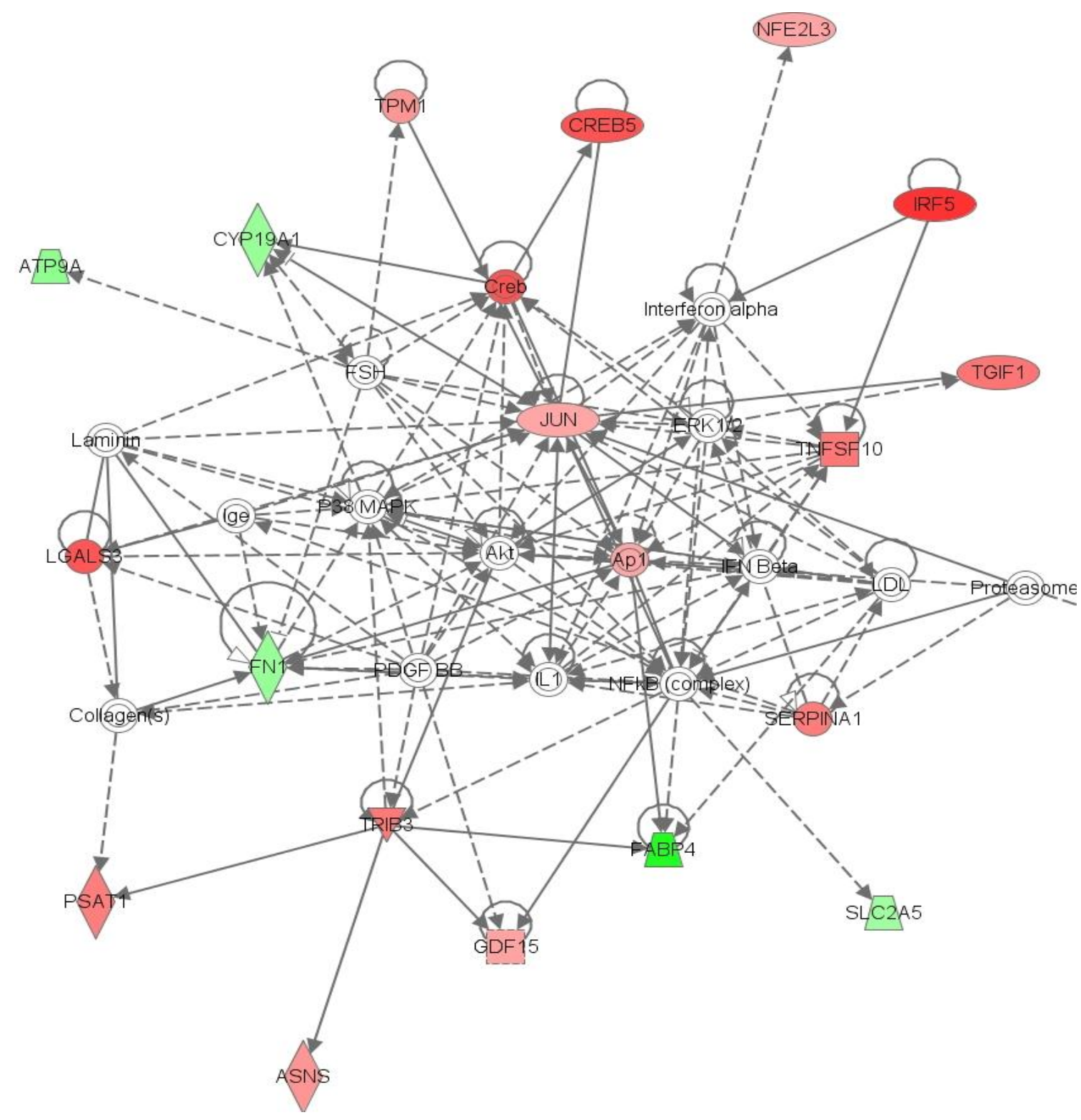

Figura 40. Mapa de via para receptores de célula $\mathbf{T}$ e reposta imune em T1. A figura mostra 20 genes representativos de receptores de membrana ( 0 , enzimas $(\diamond)$, reguladores de transcrição ( $\sigma$ ), transportadores ( $\triangle$ citocinas $(\square)$ e outros $(O)$ que relacionam-se direta ou (linha fechada) ou indiretamente (linha traçejada) independente de sua regulaçao (super-regulados em vermelho e reprimidos em verde). 


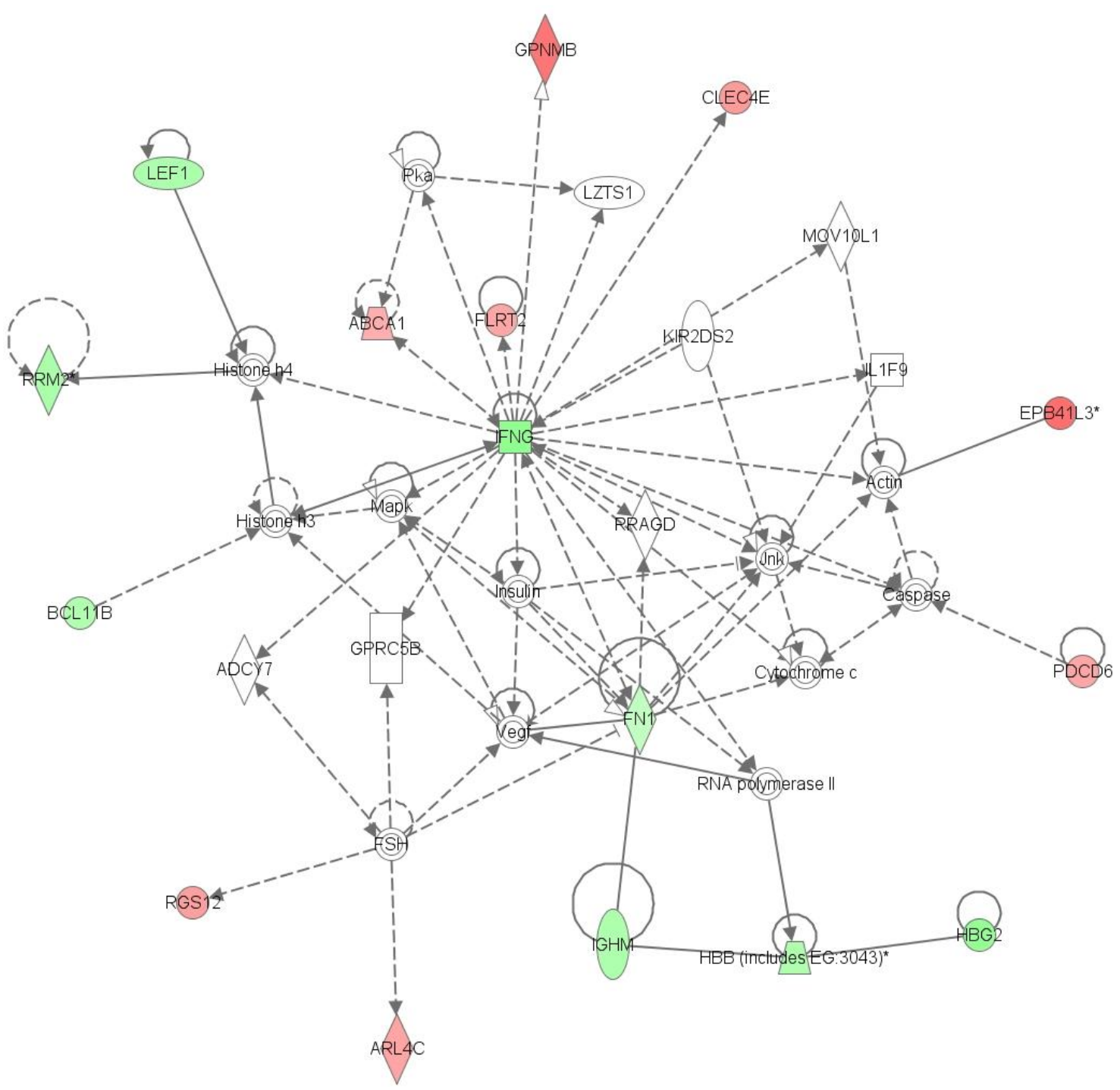

Figura 41. Mapa da via do Interfe ron em T2. A figura mostra 21 genes representativos de receptores de membrana $(0)$, enzimas $\diamond)$, reguladores de transcrição (ठ), transportadores $(\square)$, citocinas $\square$ ) e outros $\bigcirc$ ) que relacionam-se direta ou (linha fechada) ou indiretamente (linha traçejada) independente de sua regulaçao (superregulados em vermelho e reprimidos em verde). 
DISCUSSÃO 


\section{DISCUSSÃO}

Células dendríticas são reconhecidas como potentes adjuvantes naturais capazes de despertar a resposta mediada por células T citotóxicas e T auxiliadoras, devido o seu papel central de célula apresentadora de antígenos (APC) no sistema imune (Steinman e Cohn, 1973; Banchereau e Steinman, 1998; Usharauli, 2005). Neste sentido, sistemas artificiais de obtenção de células dendríticas a partir de monócitos (Mo-DCs) tem possibilitado o amplo emprego deste artifício em protocolos de vacinas contra tumores e, principalmente, contra o HIV-1.

Entende-se que parte do sucesso das vacinas de Mo-DC esta relacionado aos fatores envolvidos no processo de confecção. Fatores como, método de cultura, efeito da exposição ao antígeno vacinal e background genético das células monocíticas, podem influenciar os estados funcionais de diferenciação e maturação das DCs.

Os estados funcionais são caracterizados por intensa atividade celular regulada por centenas de genes expressos ou suprimidos. Atualmente, a genômica funcional ou transcriptômica, dispõe de metodologias capazes de avaliar a expressão dos extensos programas genéticos (perfil genético) modulados no processo de confecção da vacina. (Castagnoli e Granucci, 2002)

Além de auxiliar no avanço do conhecimento da complexidade funcional das DCs, o emprego de metodologias de análise de expressão gênica em larga escala (microarray) no desenho de vacinas pode acelerar e otimizar o sua produção ao fornecer informações que facilitam o estabelecimento da relação entre as estruturas moleculares e a resposta imunológica (Regnström, 2008).

O presente estudo avaliou o transcriptoma de Mo-DC provenientes de pacientes cronicamente infectados, em três momentos distintos da cultura correnspondendo a um 
estado e estímulo específico, de acordo com protocolo de vacina terapêutica anti-HIV proposto por Lu e colaboradores (2004).

Vale ressaltar que diferentes estudos de perfilação de Mo-DC foram realizados para traçar a expressão de seus estados imaturo e maduro, entretanto, cada estudo possui aspectos particulares quanto a obtenção destes perfis como a condição de cultura, tipo de estímulos, tempo mantido em cultura, procedência das células monocíticas, tipo de chip e plataforma de microarray utilizados. Portanto, a discussão dos resultados encontrados neste estudo em comparação aos descritos na literatura considera tais variáveis (Ahn et al., 2002; Ju et al., 2003; Ju e Zenke, 2004). Além disso, há poucos estudos que envolvem a expressão de Mo-DC frente a exposição ao HIV-1 e seus derivados (Giri et al., 2006).

Após uma seleção estringente dos genes expressos foi evidente a participação dos 28 genes mais representativos, estatisticamente, em distintas funções da imunobiologia das DCs no estado imaturo. Por exemplo, o acionamento da via de sinalização de fatores de crescimento de colônia granulócito-macrófago (GM-CSF) e das funções de movimento e morfologia celular confirmam a dinâmica do processo de diferenciação dos monócitos em células dendríticas (Lehtonen A, et al 2007), já as vias de macropinocitose e funções de sinalização e interação célula-a-célula (CD58), resposta imune mediada por células, tráfego de células imunes e resposta inflamatória foram diretamente relacionadas ao papel de APC das DCs conforme também descrito por Tang e Saltzman, 2004. O que mais nos chamou atenção foi à sinalização de TGF- $\beta$, responsável em regular, principalmente, a diferenciação, maturação e apresentação antigênica das DCs (Li MO, et al, 2006).

O estado transitório (T1) considerado neste estudo trata-se do período de $2 \mathrm{~h}$ em que as Mo-DCs foram submetidas a exposição ao HIV autólogo inativado com AT-2, de 
acordo com estudo por microscopia confocal de Turville e colaboradores (2004), no qual $95 \%$ das Mo-DCs expostas a cepa de HIV-1 $1_{\text {bal }}$ apresentaram positividade para antígeno p24 após o mesmo período de contato. As partículas virais tratadas com AT-2 mantem as estruturas e as funções das proteínas do envelope normais, podendo infectar as células, contudo o ciclo viral é bloqueado no estágio da transcrição reversa, impedindo sua relicação (Rossio et al., 1998).

Os 143 genes selecionados em T1 relacionaram-se as funções de desenvolvimento e sinalização celular, sinalização célula-a-célula, tráfego celular, resposta imune celular, apresentação antigênica e resposta a doenças infecciosas. As principais vias e redes ativas foram relacionadas à sinalização de receptores de células T, principalmente para os ligantes da superfamília do CD28 (ICOS:ICOSL, CD28:B7, CD40L:CD40) responsáveis pelo $2^{a}$ sinal de ativação de células T (Janeway, 2004). Por exemplo, o ICOS ligante, é constitutivamente expresso em baixos níveis em células B, macrófagos e células dendríticas, e super-regulado nas APCs e em alguns tecidos nãolinfóides (incluindo o coração, pulmão e rins) pelo TNF- $\alpha$ ou LPS e durante respostas doença do enxerto contra o hospedeiro (GVHD) (Taylor PA, et al 2005)

Outras vias presentes foram à sinalização do NFAT (fator nuclear de ativação de células T), NF-kB (fator nuclear kappa B), vias es tresse oxidativo ou sinalização redox e vias de morte celular (Gilmore \& Brasier, 2006). Os fatores de transcrição ativam a produção de uma série de proteínas sinalizadoras, receptores de superfície celular, citocinas e outras proteínas efetoras envolvidas na resposta imune (Macian F, 2005). Atualmente, estudos mostram que as isoformas c1 e c2 exercem efeitos pró-apoptóticos em DCs após a exposição ao LPS, pois em condições fisiológicas, a morte da DC por apoptose após um contato com microrganismo é importante para prevenir uma ativação celular aberrante e a autoimunidade (Granucci F, et al 2009). 
A via do NF-kB está envolvida na resposta celular aos estímulos como estresse, citocinas, radicais livres, radiação ultravioleta, LDL oxidada, e antígenos virais ou bacterianos, desempenhando um papel fundamental na regulação da resposta imune à infecção e regulando a produção de mensageiros liberados durante a inflamação para o recrutamento e ativação de outras células do sistema imune (Gilmore \& Brasier, 2006). A presença do HIV, mesmo inativado, despertou programação gênica correspondente a resposta imune antiviral, processamento antigênico e também as vias de morte celular.

Dentre os 57 genes que corresponderiam ao estado maduro, 48 horas estimulado com citocinas pró-inflamatórias, nenhum correspondeu a expressão de moléculas classicamente consolidadas pela literatura como marcadores de maturação (Reis e Sousa, 2006). Entretanto, o efeito do HIV na maturação de DC é controvérsio. Alguns estudos indicam que DCs tratadas ou infectadas pelo HIV falham em super-regular os marcadores de superfície celular (Granelli-Piperno et al., 2004; Smed-Sorensen et al., 2004) e este é mediado por Vpr do HIV (Muthumani et al., 2005) ou são refratárias ao estímulo de maturação (Schnorr et al., 1997). Inversamente, outros estudos demonstram uma parcial ou anormal super-regulação dos marcadores de maturação celular, os quais são ocasionados pela interação da gp120 com as DCs, desencadeando eventos de sinalização e migração celular (Fantuzzi et al., 2004; Wilflingseder et al., 2004).

Contudo, notamos que os genes presentes estavam relacionados a funções movimento, organização, ciclo e morte celular, desenvolvimento de sistema hematológico, tráfego de células imunes, enquanto que as vias e as redes se relacionavam com sinalização de resposta de fase aguda, sinalização de receptores de morte e sinalização TGF- $\beta$ semelhante ao momento T0. Apesar de não encontrarmos genes referentes aos marcadores de maturação, a resposta da DC aparentemente não é comprometida, uma vez que possuímos dados da resposta in vitro, proveniente de 
trabalhos realizados paralelamente com as células dos mesmos pacientes em nosso laboratório (Oshiro et al, dados não publicados).

Os perfis de expressão das DCs nos três momentos da cultura revelam como o processo de confecção da vacina terapêutica anti-HIV influencia a programação de maturação das DCs. A expressão dos genes encontrados corrobora com diferentes trabalhos de perfilação de expressão de células dendríticas submetidas aos mais variados estímulos (Ju \& Zenke, 2004; Giri et al, 2006).

Vale salientar, que em estudos de transcriptoma, a quantidade de dados obtidos é muito grande e o número de técnicas de análise passíveis de serem utilizadas são ainda maiores. Outra característica marcante é o uso intenso da bioinformática, que introduz ferramentas analíticas complexas baseadas em linguagem computacional e estatística (Göhlmann e Talloen, 2009).

A opção de aplicar duas técnicas estatísticas permitiu selecionar os genes que possuíam alta probabilidade de expressão diferencial, evitando falsos positivos, no intuito de utilizá-los posteriormente em experimentos comprobatórios de PCR quantitativa. Contudo, a elevada estringência na análise pode ter desconsiderado genes de significado biológico importante, em detrimento do significado estatístico. A vantagem da metodologia de microarray é a possibilidade de re-análise dos dados por outros métodos estatísticos menos estringentes, considerando o desenho original do estudo.

Em relação a sugestão de um perfil de expressão característica dos indivíduos responsivos in vitro ao modelo vacinal, não encontramos diferenças significativas ao reanalizarmos os dados considerando os pacientes com melhor resposta in vitro na produção de IFN-gama e IL-12 quando co-cultivadas com linfócitos autólogos, de acordo com estudo aind a não publicado de Oshiro e colaboradores. 


\section{CONCLUSÃO}

De uma maneira geral foi possível observar as mudanças no perfil de transcrição dos genes nos diferentes momentos de cultura das Mo-DCs. As conclusões desse trabalho são as seguintes:

- $\quad$ O HIV-1 inativado induziu alterações na expressão gênica das DCs em relação ao momento T0, ativando as vias de sinalização CD28 e ICOS, e regulação da resposta imune por NFAT relacionados com apresentação antigênica e resposta específica antiHIV-1; além de ativar a via do NF-kB que aumenta a transcrição de DNA após diferentes estímulo;

- Apesar de não encontrarmos genes referentes aos marcadores clássicos de maturação, os genes presentes estavam relacionados a diversas funções do ciclo celular e resposta imune;

- Alguns genes candidatos foram identificados nas células infectadas como potencialmente envolvidos no processo de interação com o HIV;

- Os três momentos da cultura revelaram diferentes perfis de expressão das DCs que podem futuramente contribuir com o entendimento da maturação das DCs na confecção da vacina terapêutica anti-HIV. 
REFERÊNCIAS 


\section{REFERÊNCIAS BIBLIOGRÁFICAS}

Adams S, O'neill DW, Bhardwaj N. Recent Advances in Dendritic Cell Biology. J Clin Immunol. 2005;25(3):177-88

Ahn, JH, Lee Y, Jeon C, Lee SJ, Lee BH, Choi KD, Bae YS. Identification of the genes differentially expressed in human dendritic cell subsets by cDNA subtraction and microarray analysis. Blood. 2002;100(5):1742-54.

Ahuja SS, Reddick RL, Sato N, Montalbo E, Kostecki V, Zhao W, Dolan MJ, Melby PC, Ahuja SK. Dendritic cell (DC)-based anti-infective strategies: DCs engineered to secrete IL-12 are a potent vaccine in a murine model of an intracellular infection. J Immunol. 1999;163(7):3890-7.

Albert ML, Pearce SFA, Francisco LM, Sauter B, Roy P, Silvertein RL, Bhardwaj N. Immature dendritic cells phagocytose apoptotic cells via $\alpha v \beta 5$ and CD36, and crosspresent antigens to citotoxic T lymphocytes. J Exp Med. 1998;188(7):1359-68.

Ardavín C, Martínez del Hoyo G, Martín P, Anjuère F, Arias CF, Marín AR, Ruiz S, Parrillas V, Hernández H. Origin and differentiation of dendritic cells. Trends Immunol. 2001;22(12):691-700.

Aricò E, Wang E, Tornesello ML, Tagliamonte M, Lewis GK, Marincola FM, Buonaguro FM, Buonaguro L. Immature monocyte derived dendritic cells gene expression profile in response to Virus-Like Particles stimulation. J Transl Med. $2005 ; 3: 45$.

Banchereau J, Briere F, Caux C, Davoust J, Lebecque S, Liu YJ, Pulendran B, Palucka K. Immunobiology of dendritic cells. Annual Review Immunology. 2000;18:767-811.

Banchereau J, Steinman RM. Dendritic cells and the control of immunity. Nature. 1998;392:245-252.

Barré-Sinoussi F, Chermann JC, Rey F, Nugeyre MT, Chamaret S, Gruest J, Dauguet C, Axler-Blin C, Vézinet-Brun F, Rouzioux C, Rozenbaum W, Montagnier L.. Isolation of a T-lymphotropic retrovirus from a patient at risk for acquired immune deficiency syndrome (AIDS). Science 1983;220:868-71.

Berberich C, Ramirez-Pineda JR, Hambrecht C, Alber G, Skeiky YAW, Moll H. Dendritic cell (DC)- based protection against an intracellular pathogen is dependent upon DC-derived IL-12 and can be induced by molecularly defined antigens. J. Immunol. 2003;170,3171-3179. 
Binneck E. As ômicas: Integrando a bioinformação. Biotecnologia Ciência e. Desenvolvimento. 2004;1(32):28-37.

Blohm DH, Elie AG. New developments in microarray technology. Current Opinion in Biotechnology. 2000;12:41-47.

Boes T, Neuhäuser M. Normalization for Affymetrix GeneChips. Methods Inf Med. 2005;44(3):414-7.

Bolstad BM, Irizarry RA, Astrand M, Speed TP. A comparison of normalization methods for high density oligonucleotide array data based on variance and bias. Bioinformatics. 2003;19(2):185-93.

Bourguin I, Moser M, Buzoni-Gatel D, Tielemans F, Bout D, Urbain J, Leo O. Murine dendritic cells pulsed in vitro with Toxoplasma gondii antigens induce protective immunity in vivo. Infect. Immun. 1998;66,4867-4874.

Brander C, Frahm N, Walker BD. The challenges of host and viral diversity in HIV vaccine design. Curr Opin Immunol. 2006;18(4):430-7.

Breitling R. and Armengaud P. and Amtmann A. and Herzyk P. Rank products: a simple, yet powerful, new method to detect differentially regulated genes in replicated microarray experiments. FEBS Letters, $573: 83-92,2004$.

Brown PO, Botstein D. Exploring the new world of the genome with DNA microarrays. Nat Genet. 1999;21(1 Suppl):33-7.

Butte A: The use and analysis of microarray data. Nat Rev Drug Discov 2002;1:951-60.

Buve A, Carael M, Hayes RJ, et al: The multicentre study on factors determining the differential spread of HIV in four African cities: summary and conclusions. AIDS 2001; 15(Suppl4):S127-S131.

Calza S, Raffelsberger W, Ploner A, Sahel J, Leveillard T, Pawitan Y. Filtering genes to improve sensitivity in oligonucleotide microarray data analysis. Nucleic Acids Res. 2007;35(16):e102.

Castagnoli PR, Granucci F. Opinion: Interpretation of the complexity of innate immune responses by functional genomics. Nat Rev Immunol. 2002;2:881-9.

Chaudhuri JD. Genes arrayed out for you: the amazing world of microarrays. Med Sci Monit. 2005;11(2):RA52-62. 
Collman RG, Perno CF, Crowe SM, Stevenson M, Montaner LJ. HIV and cells of macrophage/dendritic lineage and other non-T cell reservoirs: new answers yield new questions. J. Leukoc. Biol. 2003;74:631-634.

Connolly NC, Whiteside TL, Wilson C, Kondragunta V, Rinaldo CR, Riddler SA. Therapeutic immunization with human immunodeficiency virus type 1 (HIV-1) peptideloaded dendritic cells is safe and induces immunogenicity in HIV-1-infected individuals. Clin Vaccine Immunol. 2008;15(2):284-92.

Cui X, Hwang JT, Qiu J, Blades NJ, Churchill GA. Improved statistical tests for differential gene expression by shrinking variance components estimates. Biostatistics. 2005;6(1):59-75.

d'Ostiani CF, Del Sero G, Bacci A, Montagnoli C, Spreca A, Mencacci A, Castagnoli PR, Romani L. Dendritic cells discriminate between yeasts and hyphae of the fungus Candida albicans: implications for initiation of $\mathrm{T}$ helper cell immunity in vitro and in vivo. J. Exp. Med. 2000;191,1661-1673.

Demangel C, Bean AG, Martin E, Feng CG, Kamath AT, Britton WJ. Protection against aerosol Mycobacterium tuberculosis infection using Mycobacterium bovis Bacillus Calmette Guérin-infected dendritic cells. Eur. J. Immunol. 1999;29,1972-1979.

Des Jarlais DC, Dehne K, Casabona J.HIV surveillance among injecting drug users. AIDS. 2001;15 Supp13:S13-22.

Donaghy H, Stebbing J, Patterson S. Antigen presentation and the role of dendritic cells in HIV. Curr Opin Infect Dis 2004;17:1-6.

Dorrell L, Yang H, Iversen AK, Conlon C, Suttill A, Lancaster M, Dong T, Cebere I, Edwards A, Rowland-Jones S, Hanke T, McMichael AJ. Therapeutic immunization of highly active antiretroviral therapy-treated HIV-1 infected patients: safety and immunogenicity of an HIV-1 gag/polyepitope DNA vaccine. AIDS. 2005;19:1321-23

Dorrell L. Therapeutic immunization for the control of HIV-1: where are we now? Int J STD AIDS. 2006;17(7):436-41.

Douek DC, Brenchley JM, Betts MR, Ambrozak DR, Hill BJ, Okamoto Y, Casazza JP, Kuruppu J, Kunstman K, Wolinsky S. HIV preferentially infects HIV-specific CD4+ T cells. Nature. 2002;417:95-98.

Egan MA. Towards the development of a therapeutic vaccine for the treatment of HIV-1 infection: are we closer than ever? Expert Rev Vaccines. 2007;6(3):289-91. 
Fanger NA, Wardwell K, Shen L, Tedder TF, Guyre PM. Type I (CD64) and Type II (CD32) Fc gama receptor-mediated phagocytosis by human blood dendritic cells. J Immunol. 1996;157:541-48.

Fantuzzi, L., C. Purificato, K. Donato, F. Belardelli, and S. Gessani. 2004. Human immunodeficiency virus type 1 gp120 induces abnormal maturation and functional alterations of dendritic cells: a novel mechanism for AIDS pathogenesis. J. Virol. 78: 9763-9772.

Feng S, Wolfinger RD, Chu TM. Empirical Bayes analysis of variance component models for microarray data. Journal of Agricultural Biological and Environmental Statistics. 2006;11(2):197-209.

Flexner C. HIV drug development: the next 25 years. Nat Rev Drug Discov. 2007;6(12):959-66.

Flohé SB, Bauer C, Flohé S, Moll H. Antigen pulsed epidermal Langerhans cells protect susceptible mice from infection with the intracellular parasite Leishmania major. Eur. J. Immunol. 1998;28:3800-3811.

Gallo RC, Sarin PS, Gelmann EP, Robert-Guroff M, Richardson E, Kalyanaraman VS, Mann D, Sidhu GD, Stahl RE, Zolla-Pazner S, Leibowitch J, Popovic M. Isolation of human T-cell leukemia virus in acquired immune deficiency syndrome (AIDS). Science. 1983;220:865-7.

Gao F, Bailes E, Robertson DL, Chen Y, Rodenburg CM, Michael SF, Cummins LB, Arthur LO, Peeters M, Shaw GM, Sharp PM, Hahn BH. Origin of HIV-1 in the chimpanzee Pan troglodytes troglodytes. Nature. 1999;397(6718):436-41.

García F, Lejeune M, Climent N, Gil C, Alcamí J, Morente V, Alós L, Ruiz A, Setoain J, Fumero E, Castro P, López A, Cruceta A, Piera C, Florence E, Pereira A, Libois A,

González N, Guilá M, Caballero M, Lomeña F, Joseph J, Miró JM, Pumarola T, Plana M, Gatell JM, Gallart T. Therapeutic immunization with dendritic cells loaded with heat-inactivated autologous HIV-1 in patients with chronic HIV-1 infection. J Infect Dis 2005;191:1680-5.

George-Chandy A, Mielcarek N, Nordstrom I, Holmgren J, Eriksson K. Vaccination with Bordetella pertussis-pulsed autologous or heterologous dendritic cells induces a mucosal antibody response in vivo and protects against infection. Infect. Immun. 2001;69:4120-4124.

Girard MP, Osmanov SK, Kieny MP. A review of vaccine research and development: the human immunodeficiency virus (HIV). Vaccine. 2006;24(19):4062-81. 
Giri MS, Nebozhyn M, Showe L, Montaner LJ. Microarray data on gene modulation by HIV-1 in immune cells: 2000-2006. J Leukoc Biol. 2006 Nov;80(5):1031-43.

Gluckman JC, Canque B, Rosenzwajg M. Dendritic Cells: A Complex Simplicity. Transplantation. 2002;73:S3-S6.

Göhlmann H, Talloen W. Gene expression studies using Affymetrix microarrays. $1^{\text {st }}$ ed. Boca Raton: Chapman \& Hall/CRC, 2009.

Gottlieb MS, Schroff R, Schanker HM, Weisman JD, Fan PT, Wolf RA, Saxon A. Pneumocystis carinii pneumonia and mucosal candidiasis in previously healthy homosexual men. N Engl J Med. 1981;305:1425-1431.

Graham BS. New approaches to vaccine adjuvants: inhibiting the inhibitor. PLoS Med. 2006;3(1):e57.

Granelli-Piperno, A., A. Golebiowska, C. Trumpfheller, F. P. Siegal, and R. M. Steinman. 2004. HIV-1-infected monocyte-derived dendritic cells do not undergo maturation but can elicit IL-10 production and T cell regulation. Proc. Natl. Acad. Sci. USA 101: 7669-7674.

Granucci F, Vizzardelli C, Virzi E, Rescigno M, Castagnoli PR. Transcriptional reprogramming of dendritic cells by differentiation stimuli. Eur. J. Immunol. 2001;31:2539-2546.

Harman AN, Wilkinson J, Bye CR, Bosnjak L, Stern JL, Nicholle M, Lai J, Cunningham AL. HIV induces maturation of monocyte-derived dendritic cells and Langerhans cells. J Immunol. 2006;177(10):7103-13.

Hiendleder S, Bauersachs S, Boulesteix A, Blum H, Arnold GJ, Fröhlich T, Wolf E. Functional genomics: tools for improving farm animal health and welfare. Rev Sci Tech. 2005;24(1):355-77.

Hogan CM, Hammer SM. Host Determinants in HIV Infection and Disease. Annals of Internal Medicine. 2001;134:761-76

Hong F. and Breitling R. and Mcentee C.W. and Wittner B.S. and Nemhauser J.L. and Chory J. RankProd: a bioconductor package for detecting differentially expressed genes in meta-analysis. Bioinformatics, 22(22):2825-2827, 2006.

Huang Q, Liu D, Majewski P, Schulte LC, Korn JM, Young RA, Lander ES, Hacohen $\mathrm{N}$. The plasticity of dendritic cell responses to pathogens and their components. Science 2001;294:870-875. 
IAVI - International AIDS Vaccine Initiative. AIDS Vaccine Blueprint 2006: Actions to Strengthen Global Research and Development. New York. IAVI.2006

IAVI - International AIDS Vaccine Initiative. AIDS Vaccine Blueprint 2008: A Challenge to the Field, a Roadmap for Progress. New York. IAVI. 2008

Ide F, Nakamura T, Tomizawa M, Kawana-Tachikawa A, Odawara T, Hosoya N,

Iwamoto A. Peptide-loaded dendritic-cell vaccination followed by treatment interruption for chronic HIV-1 infection: a phase 1 trial. J Med Virol. 2006;78:711-8.

Irizarry RA, Hobbs B, Collin F, Beazer-Barclay YD, Antonellis KJ, Scherf U, Speed TP. Exploration, normalization, and summaries of high density oligonucleotide array probe level data. Biostatistics. 2003;4(2):249-64.

Izmailova E, Bertley FM, Huang Q, Makori N, Miller CJ, Young RA, Aldovini A. HIV1 Tat reprograms immature dendritic cells to express chemoattractants for activated $\mathrm{T}$ cells and macrophages. Nat Med. 2003;9(2):191-7.

Jaluria P, Konstantopoulos K, Betenbaugh M, Shiloach J.A perspective on microarrays: current applications, pitfalls, and potential uses. Microb Cell Fact. 2007;6:4.

Jones KS. Biomaterials as vaccine adjuvants. Biotechnol Prog. 2008;24(4):807-14.

Ju XS, Hacker C, Madruga J, Kurz SM, Knespel S, Blendinger G, John SR, Zenke M. Towards determining the differentiation program of antigen-presenting dendritic cells by transcriptional profiling. European Journal of Cell Biology. 2003;82:75-86

Ju XS, Zenke M. Gene expression profiling of dendritic cells by DNA microarrays. Immunobiology.2004;209:155-161

Kafatos FC, Jones CW, Efstratiadis A.Determination of nucleic acid sequence homologies and relative concentrations by a dot hybridization procedure. Nucleic Acids Res. 1979;7(6):1541-52.

Kahn JO, Cherng DW, Mayer K, Murray H, Lagakos S. Evaluation of HIV-1 immunogen, an immunologic modifier, administered to patients infected with HIV having 300 to $549 \times 10(6) / \mathrm{L}$ CD4 cell counts: a randomized controlled trial. JAMA. 2000;284:2193-202

Kaufman L, Rousseeuw PJ. Finding groups in data: An introduction to cluster analysis. Wiley, New York, 1990. 
Kaufmann D, Pantaleo G, Sudre P, Telenti A. CD4-cell count in HIV-1-infected individuals remaining viraemic with highly active antiretroviral therapy (HAART). Swiss HIV Cohort Study. Lancet. 1998;351(9104):723-4.

Kilby JM, Bucy RP, Mildvan D, Fischl M, Santana-Bagur J, Lennox J, Pilcher C, Zolopa A, Lawrence J, Pollard RB, Habib RE, Sahner D, Fox L, Aga E, Bosch RJ, Mitsuyasu R; Adult AIDS Clinical Trials Group A5024 Protocol Team. A randomized, partially blinded phase 2 trial of antiretroviral therapy, HIV-specific immunizations, and interleukin- 2 cycles to promote efficient control of viral replication (ACTG A5024). J Infect Dis. 2006;194(12):1672-6.

Knight SC. Dendritic cells and HIV infection: immunity with viral transmission versus compromised cellu lar immunity? Immunobiology. 2001;204:614-621.

Kohonen T: The self-organizing map. Proceedings of the IEEE 1990;78:1464-80.

Korber B, Muldoon M, Theiler J, Gao F, Gupta R, Lapedes A, Hahn BH, Wolinsky S, Bhattacharya T. Timing the ancestor of the HIV-1 pandemic strains. Science. 2000;288(5472):1789-96.

Korenberg MJ. Microarray data analysis : methods and applications. $1^{\text {st }}$ ed. New Jersey: Humana Press Inc, 2007.

Kundu SK, Engleman E, Benike C, Shapero MH, Dupuis M, van Schooten WC, Eibl M, Merigan TC. A pilot clinical trial of HIV antigen-pulsed allogeneic and autologous dendritic cell therapy in HIV-infected patients. AIDS Res Hum Retroviruses. 1998;14:551-60.

Larsson M. HIV-1 and the hijacking of dendritic cells: a tug of war. Springer Semin Immun. 2005;26:309-328

Ledergerber B, Egger M, Opravil M, Telenti A, Hirschel B, Battegay M, Vernazza P, Sudre P, Flepp M, Furrer H, Francioli P, Weber R. Clinical progression and virological failure on highly active antiretroviral therapy in HIV-1 patients: a prospective cohort study. Swiss HIV Cohort Study. Lancet. 1999;353(9156):863-8.

Lehtonen A, Ahlfors H, Veckman V, Miettinen M, Lahesmaa R, Julkunen I. Gene expression profiling during differentiation of human monocytes to macrophages or dendritic cells. J Leukoc Biol. 2007 Sep;82(3):710-20. Epub 2007 Jun 26.

Lemckert AA, Goudsmit J, Barouch DH. Challenges in the search for an HIV vaccine. Eur J Epidemiol. 2004;19(6):513-6. 
Letvin NL. Progress and obstacles in the development of an AIDS vaccine. Nat Rev Immunol. 2006;6(12):930-9.

Lévy Y, Gahéry-Ségard H, Durier C, Lascaux AS, Goujard C, Meiffrédy V, Rouzioux C, El Habib R, Beumont-Mauviel M, Guillet JG, Delfraissy JF, Aboulker JP; ANRS 093 Study Group. Immunological and virological efficacy of a therapeutic immunization combined with interleukin-2 in chronically HIV-1 infected patients. AIDS. 2005;19:279-86

Li MO, Wan YY, Sanjabi S, Robertson AK, Flavell RA.Transforming growth factorbeta regulation of immune responses. Annu Rev Immunol. 2006;24:99-146. Review.

Lipshutz RJ, Fodor SP, Gingeras TR, Lockhart DJ. High density synthetic oligonucleotide arrays. Nat Genet. 1999;21(1 Suppl):20-4.

Liu YJ, Kanzler H, Soumelis V, Gilliet M. Dendritic cell lineage, plasticity and crossregulation. Nature Immunology. $2001 ; 2: 585-589$

Liu YJ. Dendritic cell subsets and lineages, and their functions in innate and adaptive immunity. Cell. 2001;106:259-262.

López CB, Sesma AF, Czelusniak SM, Schulman JL, Moran TM. A mouse model for immunization with ex vivo virus- infected dendritic cells. Cell. Immunol. 2000;206:107115.

Long Jiang The Science Creative Quarterly http://www.scq.ubc.ca/spot-your-genes-anoverview-of-the-microarray.

Lore K, Larsson M. The role of dendritic cells in the pathogenesisof HIV-1 infection. APMIS.2003;111: 776-88.

Lu W, Andrieu JM. In Vitro Human Immunodeficiency Virus Eradication by Autologous CD8 T Cells Expanded with Inactivated-Virus-Pulsed Dendritic Cells. J Virol. 2001a;75:8949-8956.

Lu W, Andrieu JM. T-cell recovery in HIV-infected patients experiencing virologic failure under highly active antiretroviral therapy. Blood. 2001b;97:1900-1901.

Lu W, Arraes LC, Ferreira WT, Andrieu JM. Therapeutic dendritic-cell vaccine for chronic HIV-1 infection. Nature Medicine. 2004;10:1359-1365.

Lu W, Wu X, Lu Y, Guo W, Andrieu JM. Therapeutic dendritic-cell vaccine for simian AIDS. Nature Medicine. 2003;9:27-32. 
Ludewig B, Ehl S, Karrer U, Odermatt B, Hengartner H, Zinkernagel RM. Dendritic cells efficiently induce protective antiviral immunity. J. Virol. 1998;72:3812-3818.

MacDonald KPA, Munster DJ, Clark GJ, Dzionek A, Schmitz J, Hart DNJ. Characterization of human blood dendritic cell subsets. Blood. 2002;100:4512-4520.

MacGregor RR, Boyer JD, Ugen KE, Lacy KE, Gluckman SJ, Bagarazzi ML, Chattergoon MA, Baine Y, Higgins TJ, Ciccarelli RB, Coney LR, Ginsberg RS, Weiner DB. First human trial of a DNA-based vaccine for treatment of human immunodeficiency virus type 1 infection: safety and host response. J. Infect. Dis. 1998;178:92-100

Markowitz M, Jin X, Hurley A, Simon V, Ramratnam B, et al. Discontinuation of antire troviral therapy commenced early during the course of human immunodeficiency virus type 1 infection, with or without adjunctive vaccination. J. Infect. Dis. 2002;186:634-43

Marques MV, Silva AM. Genômica Funcional: Transcriptoma. In: Mir L. Genômica. 1 edição. São Paulo: Editora Atheneu, 2004. 119-35.

Mastro TD, Kitayaporn D: HIV type 1 transmission probabilities: estimates from epidemiological studies. AIDS Res Hum Retroviruses. 1998;14(Suppl3):S223-S227.

Masur H, Michelis MA, Greene JB, et al: An outbreak of community acquired Pneumocystis carinii pneumonia. Initial manifestation of cellular immune dysfunction. N Engl J Med. 1981;305:1431-1438.

Mbow ML, Zeidner N, Panella N, Titus RG, Piesman J. Borrelia burgdorferi-pulsed dendritic cells induce a protective immune response against tick-transmitted spirochetes. Infect. Immun. 1997;65:3386-3390.

McIlroy D, Tanguy-Royer S, Le Meur N, Guisle I, Royer PJ, Léger J, Meflah K, Grégoire M. Profiling dendritic cell maturation with dedicated microarrays. J Leukoc Biol. 2005;78(3):794-803.

McKenna K, Beignon AS, Bhardwaj N. Plasmacytoid Dendritic Cells: Linking Innate and Adaptive Immunity. J Virol. 2005;79:17-27.

McMichael AJ, Hanke T. HIV vaccines 1983-2003. Nat Med. 2003;9(7):874-80.

McMichael AJ. HIV Vaccines. Annu. Rev. Immunol. 2006;24:227-55 
Messmer D, Messmer B, Chiorazzi N. The global transcriptional maturation program and stimuli-specific gene expression profiles of human myeloid dendritic cells. International Immunology, 2003;15:491-503

Mir KU.The hypothesis is there is no hypothesis. The Microarray Meeting, Scottsdale, Arizona, USA, 22-25 September 1999. Trends Genet. 2000;16(2):63-4.

Muthumani, K., D. S. Hwang, A. Y. Choo, S. Mayilvahanan, N. S. Dayes, K. P. Thieu, and D. B. Weiner. 2005. HIV-1 Vpr inhibits the maturation and activation of macrophages and dendritic cells in vitro. Int. Immunol. 17:103-116.

Nara PL, Nara D, Chaudhuri R, Lin G, Tobin G. Perspectives on advancing preventative medicine through vaccinology at the comparative veterinary, human and conservation medicine interface: not missing the opportunities. Vaccine. 2008;26(49):6200-11.

Piot P: The science of AIDS: A tale of two worlds. Science. 1998;280:1844-1845

Pitt J, Brambilla D, Reichelderfer P, Landay A, McIntosh K, Burns D, Hillyer GV, Mendez H, Fowler MG. Maternal immunological and virologic factors for infant human immunodeficiency virus type 1 infection: findings from the women and infants transmission study. J Infect Dis. 1997;175(3):567-75.

Rahnenführer J. Clustering algorithms and other exploratory methods for microarray data analysis. Methods Inf Med. 2005;44(3):444-8.

Regnström KJ. Pharmacogenomics in the preclinical development of vaccines: evaluation of efficacy and systemic toxicity in the mouse using array technology. In: Yan Q. Pharmacogenomics in Drug Discovery and Development. 1ed. Santa Clara: Humana Press, 2008.447-67.

Reis e Sousa C. Dendritic cells in a mature age. Nat Rev Immunol. 2006;6(6):476-83.

Richman DD. HIV chemotherapy. Nature Insight AIDS. 2001;410:995-1001.

Robinson HL. HIV/AIDS vaccines: 2007. Clin Pharmacol Ther. 2007;82(6):686-93.

Rogojina AT, Orr WE, Song BK, Geisert EE Jr. Comparing the use of Affymetrix to spotted oligonucleotide microarrays using two retinal pigment epithelium cell lines. Mol Vis. $2003 ; 9: 482-96$.

Rosenberg ES, Billingsley JM, Caliendo AM, Boswell SL, Sax PE, Kalams SA, Walker BD. Vigorous HIV-1-specific CD4+ $\mathrm{T}$ cell responses associated with control of viremia. Science. 1997;278:1447-50. 
Rossio JL, Esser MT, Suryanarayana K, Schneider DK, Bess JW Jr, Vasquez GM, Wiltrout TA, Chertova E, Grimes MK, Sattentau Q, Arthur LO, Henderson LE, Lifson JD. Inactivation of human immunodeficiency virus type 1 infectivity with preservation of conformational and functional integrity of virion surface proteins. $J$ Virol. 1998;72(10):7992-8001.

Rubbert A, Combadiere C, Ostrowski M, Arthos J, Dybul M, Machado E, Cohn MA, Hoxie JA, Murphy PM, Fauci AS, Weissman D. Dendritic cells express multiple chemokine receptors used as coreceptors for HIV entry. J Immunol. 1998;160:39333941.

Schena M, Heller RA, Theriault TP, Konrad K, Lachenmeier E, Davis RW. Microarrays: biotechnology's discovery platform for functional genomics. Trends Biotechnol. 1998;16:301-6.

Schena M, Shalon D, Davis RW, Brown PO. Quantitative monitoring of gene expression patterns with a complementary DNA microarray. Science. 1995;270(5235):467-70.

Schnorr, J. J., S. Xanthakos, P. Keikavoussi, E. Kampgen, V. ter Meulen, and S. Schneider-Schaulies. 1997. Induction of maturation of human blood dendritic cell precursors by measles virus is associated with immunosuppression. Proc. Natl. Acad. Sci. USA 94: 5326-5331.

Schön E, Harandi AM, Nordström I, Holmgren J, Eriksson K. Dendritic cell vaccination protects mice against lethality caused by genital herpes simplex virus type 2 infection. J. Reprod. Immunol. 2001;50, 87-104.

Schuler G, Schuler-Thurner B, Steinman RM. The use of dendritic cells in cancer immunotherapy. Curr. Opin. Immunol. 2003;15:138-147.

Seo J, Hoffman EP. Probe set algorithms: is there a rational best bet? BMC Bioinformatics. 2006; 7:395.

Shafer RW. Genotypic testing for human immunodeficiency virus type 1 drug resistance. Clin Microbiol Rev. 2002;15(2):247-77.

Shaffer N, Roongpisuthipong A, Siriwasin W, Chotpitayasunondh T, Chearskul S, Young NL, Parekh B, Mock PA, Bhadrakom C, Chinayon P, Kalish ML, Phillips SK, Granade TC, Subbarao S, Weniger BG, Mastro TD. Maternal virus load and perinatal human immunodeficiency virus type 1 subtype E transmission, Thailand. Bangkok Collaborative Perinatal HIV Transmission Study Group. J Infect Dis. 1999;179(3):5909. 
Shapero MH, Kundu SK, Engleman E, Laus R, van Schooten WC, Merigan TC. In vivo persistence of donor cells following adoptive transfer of allogeneic dendritic cells in HIV-infected patients. Cell Transplant. 2000;9:307-17.

Shattock RJ, Moore JP: Inhibiting sexual transmission of HIV-1 infection. Nat Rev Microbiol. 2003;1:25-34.

Shortman K, Liu YJ. Mouse and human dendritic cell subtypes. Nat Rev Immunol. 2002;2(3):151-61.

Simon, V., Ho, D. D. HIV-1 dynamics in vivo: Implications for therapy. Nature microbiology reviews. 2003;1:181-90.

Slonim DK. From patterns to pathways: gene expression data analysis comes of age. Nat Genet. 2002;32 Suppl:502-8.

Smed-Sorensen, A., K. Lore, L. Walther-Jallow, J. Andersson, and A. L. Spetz. 2004. HIV-1-infected dendritic cells up-regulate cell surface markers but fail to produce IL-12 p70 in response to CD40 ligand stimulation. Blood 104: 2810-2817.

Smyth GK. Linear models and empirical Bayes methods for assessing differential expression in microarray experiments. Stat Appl Genet Mol Biol. 2004;3 :Article3.

Steinman RM, Cohn ZA. Identification of a novel cell type in peripheral lymphoid organs of mice I: Morphology, quantitation, tis sue distribution. Journal of Experimental Medicine. 1973;137:1142-1162.

Steinman, R.M. Dendritic Cells and the Control of Immunity: Enhancing the Efficiency of Antigen Presentation. The Mount Sinai Journal of Medicine. $2001 ; 68: 160-166$.

Stekel D. Microarray Bioinformatics. $1^{\text {st }}$ ed. Cambridge: Cambridge University Press, 2003

Strathdee SA, van Ameijden EJ, Mesquita F, et al: Can HIV epidemics among injection drug users be prevented. AIDS. 1998;12(Suppl A):S71-S79.

Su H, Messer R, Whitmire W, Fischer E, Portis JC, Caldwell HD. Vaccination against chlamydial genital tract infection after immunization with dendritic cells pulsed ex vivo with nonviable chlamydiae. J. Exp. Med. 1998;188;809-818.

Talloen W, Clevert DA, Hochreiter S, Amaratunga D, Bijnens L, Kass S, G• ohlmann HWH: I/NI-calls for the exclusion of non-informative genes: a highly effective filtering tool for microarray data. Bioinformatics 2007;23 :2897-902. 
Tamayo P, Slonim D, Mesirov J, Zhu Q, Kitareewan S, Dmitrovsky E, Lander ES, Golub TR: Interpreting patterns of gene expression with self-organizing maps: methods and application to hematopoietic differentiation. Proc Natl Acad Sci U S A 1999;96:2907-12.

Tang Z, Saltzman A. Understanding human dendritic cell biology through gene profiling. Inflamm. 2004;53:424-441

Taylor PA, Panoskaltsis-Mortari A, Freeman GJ, Sharpe AH, Noelle RJ, Rudensky AY, Mak TW, Serody JS, Blazar BR. Targeting of inducible costimulator (ICOS) expressed on alloreactive T cells down-regulates graft-versus-host disease (GVHD) and facilitates engraftment of allogeneic bone marrow (BM). Blood. 2005 Apr 15;105(8):3372-80. Epub 2004 Dec 23.

Teleshova, N., Frank, I., Pope, M. Immunodeficiency virus exploitation of dendritic cells in the early steps of infection. J Leukoc Biol. 2003;74:683-690.

Turville SG, Santos JJ, Frank I, Cameron PU, Wilkinson J, Miranda-Saksena M, Dable J, Stössel H, Romani N, Piatak M Jr, Lifson JD, Pope M, Cunningham AL. Immunodeficiency virus uptake, turnover, and 2-phase transfer in human dendritic cells. Blood. 2004 15;103(6):2170-9. Epub 2003 Nov 20.

UNAIDS - Joint United Nations Programme on HIV/AIDS and World Health Organization. AIDS epidemic update 2005. Geneva. WHO. 2005

UNAIDS - Joint United Nations Programme on HIV/AIDS and World Health Organization. AIDS epidemic update 2009. Geneva. WHO. 2009

Usharauli D. Dendritic cells and the immunity/tolerance decision. Medical Hypotheses. 2005;64:112-113.

Van de Perre P, Simon A, Hittimana DG, et al: Infective and anti-infective properties of breastmilk from HIV-1 infected women. Lancet. 1993; 341:914-918.

Venkatasubbarao S. Microarrays--status and prospects. Trends Biotechnol. 2004 Dec;22(12):630-7.

Vidal M. A biological atlas of functional maps. Cell. 2001;104(3):333-9.

Walsh B, Henderson D. Microarrays and beyond: what potential do current and future genomics tools have for breeders? J Anim Sci. 2004;82 E-Suppl:E292-299.

Weissman D, Fauci AS. Role of Dendritic Cell in Immunopthgenesis of Human Immunodeficiency Virus Infection. Clinical Microbiology Review. 1997;10:358-367. 
Wilflingseder, D., B. Mullauer, H. Schramek, Z. Banki, M. Pruenster, M. P. Dierich, and H. Stoiber. 2004. HIV-1-induced migration of Mo-DC is associated with differential activation of MAPK pathways. J. Immunol. 173: 7497-7505.

Yang YH, Dudoit S, Luu P, Lin DM, Peng V, Ngai J, Speed TP. Normalization for cDNA microarray data: a robust composite method addressing single and multiple slide systematic variation. Nucleic Acids Res. 2002;30(4):e15. 
ANEXOS 


\section{ANEXOS}

\subsection{Anexo A}

\section{Descrição dos DEG super regulados em T0}

- ENTHD1. O domínio homólogo N-terminal a Epsina é um módulo encontrado nas proteínas que participam da endocitose mediada por clatrina. Domínios ENTH ligam-se proteínas e em fosfolipídeos de inositol, contribuem para a nucleação e formação de revestimentos de clatrina na membrana. Domínios ENTH também funcionam no desenvolvimento de curvatura da membrana lipídica através de remodelação durante a formação de vesículas de clatrina-revestidos.

- PSAT1. A proteína codificada por esse gene é provável uma aminotransferase fosfoserina, envolvida na proliferação celular.

- SNN. O gene codifica a Estanina, uma proteína ligada à membrana localizada nas mitocôndrias e em outras organelas vesiculares. Sua estrutura é composta por um único domínio transmembrana e uma hélice citoplasmática parcialmente incorporado na membrana. Esta envolvida na transmissão de sinais normais e nos efeitos tóxicos das organotinas.

- LGALS3. A lectina ligadora de galactoside soluvé1 3, esta envolvida nos processos de diferenciação celular; organização da matrix extracelular; desenvolvimento do citoesqueleto. Interação com as proteínas tat e rev do HIV. Lectina galactoseespecífica que se liga a IgE. Podem mediar com a alfa-3, beta-1 integrina a estimulação por CSPG4 da migração de células endoteliais. Juntamente com DMBT1, necessários para a diferenciação terminal das células epiteliais colunares durante a embriogênese

- ALDH1L2. Este gene codifica uma enzima, que pertence superfamília aldeído desidrogenase e da superfamília formil-transferase com função ainda desconhecida.

- PDCD6 (programmed cell death 6). Este gene codifica uma proteína ligante de cálcio pertencente a família de proteínas penta-EF-hand, e participa do receptor de células T, Fas, e morte celular programada induzida glicocorticóides. Podem mediar sinais regulamentado por $\mathrm{Ca}^{2}+$ ao longo da via de morte.

- CSF2RA. A proteína codificada por esse gene é a subunidade 2 alfa do receptor heterodimérica para fator estimulante de colônia, uma citocina que controla a produção, a diferenciação e a função dos granulócitos e macrófagos. A proteína 
codificada é um membro da família de receptores de citocinas. Esse gene é encontrado na região pseudo-autosomal (PAR) dos cromossomos X e Y.

- MY01G. Precursor do antígeno de histocompatibilidade menor HA-2. Genericamente, antígenos de histocompatibilidade menor (mHags) referem-se peptídeo imunogênico que, quando complexado com MHC, pode gerar uma resposta imunológica após o reconhecimento por células $\mathrm{T}$ específicas. Os peptídeos são derivados de proteínas intracelulares polimórficas, que são clivados pelas vias normais de antígeno processamento. A ligação destes peptídeos a MHC classe I ou II e suas moléculas expressão na superfície celular pode estimular respostas de células $\mathrm{T}$ e, assim, provocar a rejeição do enxerto ou doença enxerto-versus-hospedeiro (GVHD) após transplante de células-tronco hematopoéticas .

- CD58. Gene codificante para glicoproteína de adesão também conhecida como antígeno associado à função leucocitária tipo 3 (LFA-3), receptor típico de células dendríticas capaz de interagir com CD2 de células $\mathrm{T}$ para reconhecimento de antígenos especificos e induzir a reorganização do citoesqueleto de células T. Nas DCs a ligação com CD2 afeta a expressão de moléculas de superficie e a produção de citocinas inflamatórias.

\section{Descrição dos DEG reprimidos em T0}

- SCG5. Codifica uma proteína neuroendócrina 7B2, é uma proteína ácida que residem nos grânulos de secreção de células neuroendócrinas. Desempenha um papel na regulação da secreção do hormônio pituitário

- ITGB2. Gene codificante da Integrina subunidade beta 2 ou CD18, pertence a familia das integrinas de cadeia beta, são proteinas de superficie celular que podem combina-se com diferentes estruturas para formar diferentes integrinas. Por exemplo, beta 2 combina com a cadeia alfa L ou CD11a para formar LFA-1 (antigeno associado a função leucocitária 1), combina com a cadeia alfa M ou CD11b para formar a integrina Mac-1 (antígeno macrofágico 1), e CD11c para forma receptor de complemento C3. Integrinas são conhecidos para participar na adesão celular, bem como sinalização mediada pela superfície celular. Defeitos nesse gene são a causa da deficiência de adesão leucocitária tipo I (LAD1).

- HHLA2. Gene poliadenilado com repetições terminais longas (LRT) da família dos retrovirus endogeno humanos (HERVs), sua função ainda é desconhecida. 


\subsection{Anexo B}

\section{Descrição dos DEG super regulados em T1}

- CLEC7A. Este gene codifica um membro superfamília das lectinas tipo-C. A glicoproteína codificada é um pequeno receptor de membrana tipo II com um domínio extracelular tipo-C lectina-simile e um domínio citoplasmático com um immunoreceptor com motivos de ativação baseado em tirosina. Ele funciona como um padrão de reconhecimento do receptor que reconhece uma variedade de beta-1,3ligante e beta-1,6-ligante de glucanos de fungos e plantas, desenpenhando um papel na resposta imune inata.

- ZFYVE16. Proteína endossomal implicada na regulação do tráfico de membrana. É caracterizada pela presença de um fosfatidilinositol 3-fosfato-binding dominio fyve posicionado no meio da molécula.

- EPB41L3. Genes envolvido com proteinas que participam da organização do citoesqueleto de actina cortical

- GPNMB. A proteína codificada por este gene é um tipo I, glicoproteína transmembrana que mostra homologia com o precursor pMEL17, um melanócitoproteína específica. GPNMB mostra expressão nos melanoma metastático de células humanas e xenotransplantes, mas não demonstra expressão nas linhagem de células altamente metastáticas. GPNMB podem estar envolvidos no retardo do crescimento e redução do potencial metastático.

- KCNJ15. Os canais de potássio estão presentes na maioria das células de mamíferos, onde participam de uma ampla gama de respostas fisioló gicas. A proteína codificada por esse gene é uma proteína da membrana integrante e retificador ativo tipo canal de potássio. A proteína codificada tem uma maior tendência para permitir o fluxo e influxo de potássio em uma célula.

- PPM2C. Piruvato desidrogenase (E1) é um dos três componentes (E1, E2 e E3) do complexo piruvato desidrogenase grande. Piruvato desidrogenase quinase catalisa a fosforilação de resíduos de serina de E1 para inativar o componente E1 e inibir o complexo. Fosfatases Piruvato desidrogenase catalisa a desfosforilação e ativação do componente E1 para reverter os efeitos da piruvato desidrogenase quinase. Piruvato desidrogenase fosfatase é um heterodímeros constituídos de subunidades catalíticas e reguladoras. Duas subunidades catalíticas foram relatados; um se expressa predominantemente no músculo esquelético e outro é muito mais abundante no fígado. A subunidade catalítica, codificada por esse gene, é a primeira, e pertence à proteína fosfatase 2C (PP2C superfamília). Junto com o complexo piruvato desidrogenase e piruvato desidrogenase quinase, esta enzima está localizada na matriz mitocondrial. 
- PTPRE. A proteína codificada por este gene é um membro da proteína tirosina fosfatase (PTP família). PTP são conhecidas por serem moléculas sinalizadoras que regulam uma grande variedade de processos celulares, incluindo o crescimento celular, diferenciação, ciclo mitótico, e transformação oncogênica. Estudos do gene semelhante nos ratos sugerem as funções reguladoras do PTP em vias de transdução de sinal RAS relacionadas, citocinas induzida SATA sinalização, bem como a ativação de canais de potássio $\mathrm{K}^{+}$.

\section{Descrição dos DEG reprimidos em T1}

- CLC. Lisofosfolipases são enzimas que atuam sobre membranas biológicas para regular a lisofosfolipídeos multifuncionais. A proteína codificada por este gene é uma lisofosfolipase expressa em geral nos eosinófilos e basófilos. Hidrolisa lisofosfatidilcolina para Glicerilfosforilcolina e ácidos graxos livres. Esta proteína pode possuir as atividades vinculadas aos carboidrato ou IgE. É uma proteína estrutural e funcionalmente ligados à família das galectina com proteínas betagalactosideas. Pode estar associada com inflamação e algumas leucemias mielóides.

- MAL. A proteína codificada por esse gene é uma proteína integral de membrana altamente hidrofóbica pertencente à família de proteolipídios MAL. A proteína fica localizada no retículo endoplas mático das células $\mathrm{T}$ e é uma proteína participante na transdução de sinal em células T. Além disso, este proteolipideo tambem está localizada na mielina compacta de células do sistema nervoso e tem sido implicado na função e/ou biogênese da mielina. A proteína desempenha um papel na formação, estabilização e manutenção dos microdomínios enriquecido glicosfingolipideos de membrana.

- IFNG Este gene codifica um membro da família do Interferon Tipo II. A proteína codificada é uma citocina solúvel com propriedades anti-tumor imunomoduladoras, antivirais e um potente ativador de macrófagos. Mutações nesse gene são associadas com anemia aplástica.

- CYP19A1. Este gene codifica um membro da superfamília de enzimas do citocromo $\mathrm{P} 450$. As proteínas do citocromo P450 estão monooxigenases que catalisam muitos reações envolvidos no metabolismo de drogas e síntese do colesterol, esteróides e outros lípidos. Esta proteína localiza-se no retículo endoplasmático e catalisa as últimas etapas da biossíntese de estrogênio, três hidroxilações sucessivas do anel A de andrógenos. Mutações nesse gene pode resultar em aumentada ou diminuída atividade da aromatase, os fenótipos associados sugerem que o estrogênio funciona tanto como um hormônio esteróide e em crescimento ou difere nciação. 


\subsection{Anexo C}

\section{Seleção dos 10 DEG em T2}

\section{Descrição dos DEG super regulados em T2}

- IRF5. Este gene codifica um membro do fator regulador de interferon (IRF família), um grupo de fatores de transcrição, com papéis diversos, incluindo, ativação interferon mediada vírus e a modulação do crescimento celular, diferenciação, apoptose e atividade do sistema imunológico.

- CREB5. O produto deste gene pertence ao CRE (elemento de resposta cAMP)família de proteínas de ligação. A proteína codificada se liga especificamente ao CRE como um homodímero ou de heterodímeros com c-Jun ou CRE-BP1, e funciona como um trans-ativador dependentes de CRE.

- TGIF1. A proteína codificada por este gene é um membro superclasse de homeodominios atípico da extensão de três loop de aminoácidos (Tale). Além de seu papel na inibição da 9-cis-ácido retinóico dependente da ativação da transcrição RXR alfa do ácido retinóico elemento sensível, a proteína é um co-repressor transcricional ativos de SMAD2 e podem participar na transmissão de sinais nuclear durante o desenvolvimento. Mutações nesse gene são associadas com holoprosencefalia do tipo 4, que é uma anomalia estrutural do cérebro.

- TNFSF10. Proteína codificada por esse gene é uma citocina que pertence ao fator de necrose tumoral (TNF família) ligante. Esta proteína, preferencialmente, induz apoptose em células transformadas e tumorais, mas não aparece para matar as células normais, embora seja expressa com um nível significativo na maioria dos tecidos normais. Esta proteína se liga a vários membros da superfamília de receptores TNF, incluindo TNFRSF10A/TRAILR1,TNFRSF10B/TRAILR2, TNFRSF10C/TRAILR3, TNFRSF10D/TRAILR4, e possivelmente também para TNFRSF11B/OPG. A atividade dessa proteína pode ser modulada pela ligação aos receptores chamariz TNFRSF10C/TRAILR3, TNFRSF10D/TRAILR4 e TNFRSF11B/OPG que não pode induzir a apoptose. A ligação desta proteína aos seus receptores mostrou desencadear a ativação de MAPK8/JNK, caspase 8 e caspase 3 .

- TRIB3. A proteína codificada por este gene é uma proteína quinase induzida pelo fator de transcrição NF-kappaB. A proteína codificada é um regulador negativo da NF-kappaB e também pode sensibilizar as células através do e TNF e TRAILindutores de apoptose. Além disso, essa proteína pode regular negativamente a sobrevivência das células de serina-treonina quinase AKT1. 
- SERPINA1 A proteína codificada por esse gene é secretado e é um inibidor de protease serina cujo os alvos incluem a elastase, plasmina, trombina, tripsina, e ativador de plasminogênio. Defeitos neste gene podem causar enfisema ou doença hepática.

\section{Descrição dos DEG reprimidos em T2}

- FABP4 Gene que codifica a proteína de ligação de ácidos graxos encontrados nos adipócitos. Proteínas de ligação de ácidos graxos são uma família de proteínas citoplasmáticas que ligam-se a longa cadeia de ácidos graxos e outros ligantes hidrofóbicos. Os papéis das FABPs incluem captação de ácidos graxos, transporte e metabolismo.

- SCD5. É uma proteína integral da membrana do retículo endoplasmático que catalisa a formação de ácidos graxos monoinsaturados de ácidos graxos saturados. SCD pode ser um regulador chave do metabolismo energético, com um papel na obesidade e dislipidemia. Apenas 2 isoformas SCD, SCD1 (MIM 604031) e SCD5, foram identificados em humanos.

- GPR34. Receptores de proteina G acoplada tais como GPR34, são proteínas integrais de membrana contendo 7 domínios transmembrana (TMs). Estas proteínas podem transmitir sinais para o interior da célula através da ativação de proteínas $G$ heterotrimerica que por sua vez ativam as proteínas efetoras diferentes, resultando em uma resposta fisiológica.

- USP9Y. Este gene é um membro da família C19 peptidase. Ele codifica uma proteína similar a ubiquitina-proteases específicas, função desconhecida.

- FN1. Este gene codifica a fibronectina, uma glicoproteína presente na forma dimérica solúvel no plasma, e de forma dimérica ou multimérica na superfície celular e na matriz extracelular. Fibronectina está envolvida na adesão celular e migração de processos, incluindo a embriogênese, cicatrização, coagulação do sangue, de defesa do hospedeiro, e metástase. $\mathrm{O}$ gene tem três regiões sujeitas a splicing alternativo, com potencial para produzir 20 diferentes variantes de transcrição.

- TSPAN12 A proteína codificada por este gene é um membro da superfamília 4 transmembrana, também conhecida como a família tetraspanina. A maioria desses membros são proteínas de superfície celular que são caracterizados pela presença de quatro domínios hidrofóbicos. As proteínas participa dos eventos de transdução de sinal que desempenham um papel na regulação do desenvolvimento das células, ativação, crescimento e motilidade. 